Georgetown University Law Center

Scholarship @ GEORGETOWN LAW

2005

\title{
Common-Law Disclosure Duties and the Sin of Omission: Testing the Meta-Theories
}

Kathryn Zeiler

Georgetown University Law Center, zeiler@law.georgetown.edu

Kimberly D. Krawiec

University of North Carolina

Copyright 2005 by the Virginia Law Review Association; Reprinted by permission of the Virginia Law Review Association.

This paper can be downloaded free of charge from:

https://scholarship.law.georgetown.edu/facpub/279

91 Va. L. Rev. 1795-1882 (2005)

This open-access article is brought to you by the Georgetown Law Library. Posted with permission of the author. Follow this and additional works at: https://scholarship.law.georgetown.edu/facpub

Part of the Contracts Commons, and the Litigation Commons 


\section{GEORGETOWN LAW Faculty Publications}

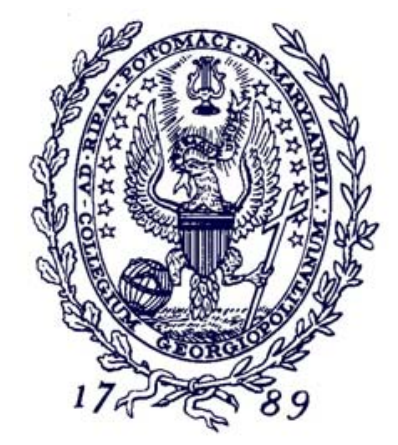

March 2010

\section{Common-Law Disclosure Duties and the Sin of Omission: Testing the Meta-Theories}

91 Va. L. Rev. 1795-1882 (2005)

\author{
Kathryn Zeiler \\ Professor of Law \\ Georgetown University Law Center \\ kmz3@law.georgetown.edu
}

Kimberly D. Krawiec

Professor of Law

University of North Carolina

School of Law

krawiec@email.unc.edu

This paper can be downloaded without charge from:

Scholarly Commons: http://scholarship.law.georgetown.edu/facpub/279/

SSRN: http: //ssrn.com/abstract $=913055$

Posted with permission of the author 


\title{
VIRGINIA LAW REVIEW
}

\begin{tabular}{lll}
\hline VOLUME 91 & DECEMBER 2005 & NUMBER 8 \\
\hline
\end{tabular}

\section{ARTICLES}

\section{COMMON-LAW DISCLOSURE DUTIES AND THE SIN OF OMISSION: TESTING THE META-THEORIES}

\author{
Kimberly D. Krawiec* and Kathryn Zeiler ${ }^{* *}$
}

INTRODUCTION

I. COLLECTION OF HYPOTHESES AND CONSTRUCTED

INDEPENDENT

VARIABLES 1800

A. The Type of Information ............................................... 1800

B. The Type of Transaction................................................... 1808

C. How the Information Was Acquired ............................... 1817

D. Characteristics of the Uninformed Party......................... 1822

E. Behavior of the Informed Party ...................................... 1825

F. Case Date..................................................................... 1827

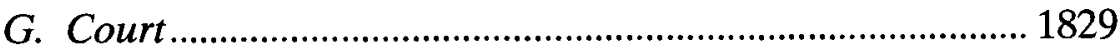

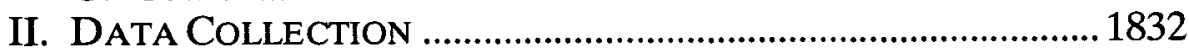

* Professor of Law, University of North Carolina. Email: krawiec@email.unc.edu. We thank workshop participants at the law schools of the University of Virginia, Georgetown University, University of Southern Cahfornia, Cornell University, Florida State University, Washington University, Emory University, the University of Illinois, and Lewis \& Clark College, audience members and fellow panelists at the 2004 Law and Society Association Annual Meeting, Scott Baker, Jeff Bauman, Bill Bratton, Caroline Brown, Steve Choi, Heidi Li Feldman, Matthew Gerke, Steve Goldberg, Michael Gottesman, David Grether, Mitu Gulati, Michael Heise, Vicki Jackson, Melissa Jacoby, Ed Kitcl, Don Langevoort, David Luban, Paul Mahoney, Anup Malani, Geoff Manne, Carrie Menkel-Meadow, John Mikhail, John Ortl, Mitt Regan, Bob Scott, Warren Schwartz, Gerry Spann, and Dan Tarullo for helpful comments on early drafts of this Article. We also are grateful to Rob Bartilucci, Josliua Ellis, Bill Forstner, Kevin Pooler, and Mark Siler for outstanding research assistance.

** Associate Professor of Law, Georgetown University Law Center. Email: zeiler@law.georgetown.edu. Internet: http://www.georgetown.edu/faculty/kmz3/. 
A. The Available Cases .......................................................... 1832

B. The Collection Process..................................................... 1833

C. Summary Statistics.............................................................. 1836

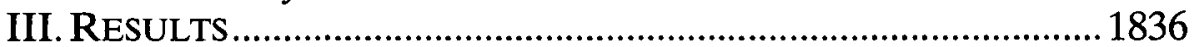

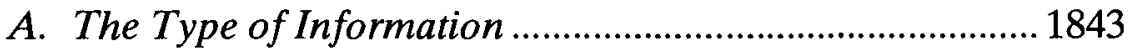

B. The Type of Transaction.................................................. 1851

C. How the Information Was Acquired ............................... 1856

D. Characteristics of the Uninformed Party.......................... 1862

E. Behavior of the Informed Party ...................................... 1864

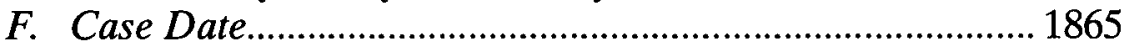

G. Court .............................................................................. 1873

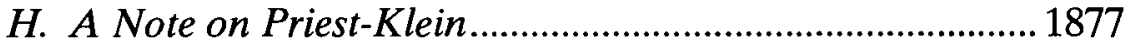

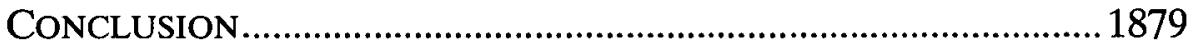

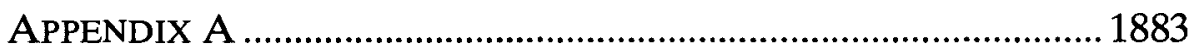

\section{INTRODUCTION}

NE of the most hotly debated questions under the common law is under what circumstances an individual has a duty to disclose relevant information unknown to the person with whom she bargains. Dozens of law review articles and treatises and over one thousand cases explore this vexing question of when and what a contracting party must disclose to her counterparty, even in the absence of explicit misleading statements. Although one frequently encounters statements that, absent a fiduciary or confidential relationship, an individual need never disclose all that she knows to her bargaining partner, this is best understood as mere rhetoric by courts, rather than an accurate statement of law. ${ }^{1}$ Even a cursory

\footnotetext{
${ }^{1}$ See, e.g., 3 Arthur Linton Corbin, Corbin on Contracts $\S 608$ (1960) ("Statements are exceedingly common, both in texts and in court opinions, that relief will not be given on the ground of mistake unless the mistake is 'mutual.' Such a broad generalization is misleading and untrue."); Anthony T. Kronman, Mistake, Disclosure, Information, and the Law of Contracts, 7 J. Legal Stud. 1, 6 (1978) ("In the past, it was often asserted that, absent fraud or misrepresentation, a unilateral mistake never justifies excusing the mistaken party from his duty to perform or pay damages. This is certainly no longer the law, and Corbin has demonstrated that in all probability it never was."); see also Heritage Ins. Co. of Am. v. First Nat'l Bank of Cicero, 629 F. Supp. 1412, 1415 (N.D. Ill. 1986) ("[N]o duty of disclosure exists absent a fiduciary duty or public trust between parties to a transaction."); French v. Vining, 102 Mass. 132,135 (1869) ("It is sometimes rather loosely said that mere silence, on the part of
} 
examination of the cases reveals, instead, that courts require full disclosure in some circumstances, but not in others.

Determining what circumstances will lead courts to intervene to correct disparities in knowledge between bargaining parties, however, has proved problematic. Courts repeatedly reach divergent results in similar, or even seemingly identical, cases and have failed to articulate a coherent or generally accepted rule as to when they will impose a duty of candor on contracting parties.

As a result, numerous legal commentators have analyzed the law of fraudulent silence (also referred to as actionable nondisclosure or actionable silence) in an attempt to identify some guiding principle that will rationalize the cases and generate accurate predictions of how courts will rule. Although some commentators point to various specific factors (for example, whether the withheld information related to a latent defect or whether the litigating parties were in a confidential or fiduciary relationship) that courts consider either alone or in some combination, others conclude that courts provide no useful rule of law. ${ }^{2}$ Still other legal scholars, most notably Professors Anthony Kronman and Kim Lane Scheppele, reject the notion that narrow doctrinal rules motivate fraudulent silence decisions and instead advance meta-theories ${ }^{3}$ (based, re-

the vendor, as to a known defect, does not amount to a fraud. But this is far from being universally true.").

${ }^{2}$ See George Spencer Bower, The Law Relating to Actionable Nondisclosure and Other Breaches of Duty in Relations of Confidence and Influence, at vi (1915) (arguing that the law of actionable nondisclosure cannot be "fit ... into the rigid framework of a code"), quoted in Kim Lane Scheppele, Legal Secrets: Equality and Efficiency in the Common Law 112 (1988); Paula J. Dalley, The Law of Deceit, 17901860: Continuity Amidst Change, 39 Anı. J. Legal Hist. 405, 407 (1995) [hereinafter Dalley, Law of Deceit] (discussing the law of fraud, including the law of fraudulent silence, and noting that "there does not seem to be any factor which accurately predicts which policy a particular court will find determinative in a particular case, other than the merits of the case"); Deborah A. DeMott, Do You Have the Right to Remain Silent?: Duties of Disclosure in Business Transactions, 19 Del. J. Corp. L. 65, 66 (1994) ("My thesis is that legal doctrine does not resolve these scenarios in a symmetrical fashion.").

${ }^{3}$ We use the terms "theories" and "meta-theories" soinewhat loosely. Some have suggested to us that, technically speaking, the field lacks a comprehensive theory to explain fraudulent silence case outcomes. Furthermore, they argue, the explanations posited by commentators such as Professors Kronman and Scheppele should be viewed as half descriptive and half normative. For these reasons, they argue, we should not take them seriously as theories that generate testable predictions. While 
spectively, on whether courts seek primarily to further economic efficiency or fairness) in an attempt to untangle the cases and illuminate the law of fraudulent silence. ${ }^{4}$

These meta-theories - along with the famous United States Supreme Court case of Laidlaw v. Organ ${ }^{5}$ - inspired this project. In Laidlaw, Organ had been bargaining over the price of 111 hogsheads of tobacco with Laidlaw's agent, Girault, on the evening of February 18, 1815, but did not reach an agreement on price before departing. During the night, three gentlemen who had been with the British fleet came ashore with news that the Treaty of Ghent had been signed, ending the war of 1812 and lifting the blockade of the port of New Orleans. One of these men was the brother of Organ's business partner (who had a one-third interest in the profits of the tobacco) and informed Organ of the news during the night.

Although the news of the war's end was to be published in a handbill early the next morning, Organ returned to Girault before

we somewhat agree with this characterization of the explanations (one of us more than the other), in fact many take these explanations seriously. See, e.g., Richard Craswell, Instrumental Theories of Compensation: A Survey, 40 San Diego L. Rev. 1135, 1165-66 n.38 (2003) (citing Professors Kronman and Scheppele as providing different theories regarding information disclosure); Wiiliam Hubbard, Communicating Entitlements: Property and the Internet, 22 Yale L. \& Pol'y Rev. 401, 416 n.89 (2004) (citing the work of Professors Scheppele and Kronman to support the claim that scholars disagree about the optimal level of disclosure). For those readers who believe we are using the term "meta-theories" too loosely, we suggest viewing this study as the first systematic test of the conventional wisdom that flows from the commentators' claims. Given our reading of the claims made by Professors Kronman, Scheppele, and others, however, we characterize the explanations as (albeit imperfect) "meta-theories" im the sense that they posit frameworks designed to organize the "data" produced by the court.

${ }^{4}$ See, e.g., Scheppele, supra note 2, at 119-24 (advocating an equality of access approach to explain the law of actionable nondisclosure); Kim Lane Scheppele, "It's Just Not Right": The Ethics of Insider Trading, 56 Law \& Contemp. Probs. 123, 125 (1993) (same); Kronman, supra note 1, at 13-15 (arguing that the law of actionable nondisclosure is best explained by the law's desire to reward those who have expended time and effort to acquire the undisclosed information); Alan Strudler, Moral Complexity in the Law of Nondisclosure, 45 UCLA L. Rev. 337, 338-39 (1997) (arguing that the law of actionable nondisclosure as applied to buyers is best explained through a deontological philosophy); Alan Strudler \& Eric W. Orts, Moral Principle in the Law of Insider Trading, 78 Tex. L. Rev. 375, 408-09 (1999) (justifying insider trading regulation on a deontological theory of "equitable disclosure").

${ }^{5} 15$ U.S. (2 Wheat.) 178 (1817). 
its release and purchased the tobacco without disclosing the news. ${ }^{6}$ A few hours later, the news was released and the price of tobacco rose significantly.

Chief Justice Marshall ruled that Organ had no duty to disclose his knowledge of the end of the war to Girault. ' Due to the brevity of Marshall's opinion, however, commentators have struggled to identify the principle underlymg the decision. In the process, several theories have emerged that purport to explain not only the Court's decision in Laidlaw, but also the large and seemingly inconsistent body of other fraudulent silence cases.

Unfortunately, many authors in the field of fraudulent silence discuss a limited number of cases that they believe support their asserted theories, without providing evidence that the chosen cases are representative and without distinguishing cases that do not support their theory. ${ }^{8}$ This Article represents the first attempt to study empirically the factors that cause courts to impose disclosure duties on bargaining parties in some circumstances, but not in others. ${ }^{9}$ We analyze data coded from 466 decisions spanning a wide array of jurisdictions and covering over two hundred years.

The results are mixed. In some instances our data support the conventional wisdom relating to common-law disclosure duties. For example, we find that courts are more likely to require the disclosure of latent, as opposed to patent, defects and are more likely to require disclosure when the parties are in a fiduciary or confidential relationship.

In other instances, our results cast doubt on much of the conventional wisdom regarding the law of fraudulent silence. First, al-

${ }^{6}$ Id. at $179,182-83$. Apparently, Girault asked Organ "if there was any news which was calculated to enhance the price or value of the article about to be purchased." Id. at 183. The lower court determined that there was no evidence that Organ's reply "suggested any thing to the said Girault, calculated to impose upon him with respect to said news," and directed the jury to find for Organ. Id. at 183-84.

${ }^{7}$ Id. at 195. Marshall did, however, remand to the lower court for a jury determination regarding Organ's response to Girault's inquiry. Id.

${ }^{8}$ See Lee Epstein \& Gary King, The Rules of Inference, 69 U. Chi. L. Rev. 1, 31-32 (2002) (criticizing the methodology of much legal empirical research).

${ }^{9}$ One prior attempt to study the cases systematically is Dalley, Law of Deceit, supra note 2. Although Professor Dalley's study is not a statistical analysis of the cases, her article is an important contribution to the literature and her findings are discussed throughout this Article. 
though it is generally understood that courts have become more likely to impose disclosure duties over time, we find that courts actually have become less likely over time to impose duties to disclose. Second, and perhaps most importantly, we find that courts are no more likely to impose disclosure duties when the information is casually acquired as opposed to deliberately acquired, and that unequal access to information by the contracting parties is not a significant factor that drives courts to find a duty to disclose. We do find, however, that when both factors are present courts are significantly more likely to force disclosure.

\section{COLlection OF HyPOTHESES AND CONSTRUCTED INDEPENDENT VARIABLES}

We examined twenty independent variables and their relationships to courts' decisions to impose a duty to disclose in fraudulent silence cases. We grouped the variables into five general classes: the type of information that was undisclosed, the type of transaction in which the parties were engaged, how the undisclosed information was acquired, the characteristics of the uninformed party, and the behavior of the informed party. We also analyzed the case decision year and the geographic region and jurisdiction of the court deciding the case.

\section{A. The Type of Information}

Commentators frequently assert that the imposition of disclosure duties depends on the type of information in question. In particular, they claim that courts are more likely to find that an informed party owes to the uninformed party a duty to disclose when the information is intrinsic in nature, relates to personal intentions or opinions, relates to latent defects, concerns a defect likely to cause bodily injury or property damage, or would have updated or corrected previously disclosed information.

\section{The Information Was Intrinsic, as Opposed to Extrinsic or} Market, Information

Some commentators argue that courts distinguish between intrinsic facts, which relate directly to the subject matter of the trans- 
action, and extrinsic facts, which relate to the market conditions or environment affecting the subject matter of the transaction, and only require the disclosure of intrinsic facts. ${ }^{10}$ Joseph Story explains the distinction as follows:

Intrinsic circumstances are properly those which belong to the nature, character, condition, title, safety, use, or enjoyment, \&c., of the subject-matter of the contract, such as natural or artificial defects in the subject-matter. Extrinsic circumstances are properly those which are accidentally connected with it, or rather bear upon it at the time of the contract, and may enhance or diminish its value or price, or operate as a motive to make or decline the contract; such as facts respecting the occurrence of peace or war, the rise or fall of markets, the character of the neighborhood, the increase or diminution of duties, or the like circumstances. ${ }^{11}$

To illustrate, in the previously discussed case of Laidlaw v. Organ, Chief Justice Marshall ruled that "the intelligence of extrinsic circumstances, which might influence the price of the commodity, and which was exclusively within the knowledge of the vendee," need not be disclosed to the vendor. ${ }^{12}$ In Laidlaw, the information concerning the end of the War of 1812 and the consequent lifting of the blockade of the port of New Orleans was extrinsic information because it did not pertain to conditions solely affecting the tobacco exchanged between Organ and Laidlaw, but instead pertained to conditions affecting the market for and price of all tobacco being shipped from New Orleans. Accordingly, it could be

${ }^{10}$ See 2 James Kent, Commentaries on American Law 377 (Legal Classics Library 1986) (1827) ("There may be some difference in the facility with which the rule [of disclosure] applies between facts and circumstances that are intrinsic, and form material ingredients of the contract, and those that are extrinsic, and form no component part of it, though they create inducements to enter into the contract, or affect the price of the article."); R.J. Pothier, Treatise on the Contract of Sale, II 242, at 147-48 (L.S. Cushing trans., Legal Classics Library 1988) (1839) ("[T]here is no doubt, that ... a buyer is not entitled to complain, that the seller has not informed him of circumstances extrinsic to the thing sold, however much he may be interested in knowing them."); 1 Joseph Story, Commentaries on Equity Jurisprudence $\$ 300$, at 301-02 (W. H. Lyon, Jr. ed., Boston, Little, Brown \& Co. 14th ed. 1918) (1834).

"1 Story, supra note $10, \& 300$, at 301-02 (footnote omitted).

${ }^{12}$ Laidlaw, 15 U.S. (2 Wheat.) at 195 (emphasis added). 
argued that Chief Justice Marshall permitted nondisclosure in that case because the undisclosed information was an extrinsic fact. If it had been an intrinsic fact, according to this theory, disclosure would have been required.

Other commentators, however, argue that the intrinsic/extrinsic distinction provides, at best, only a partial explanation. Although disclosure has been required more often with respect to intrinsic, rather than extrinsic, facts, the better explanation for such rulings, argue some scholars, is that intrinsic facts may not be readily discoverable by the uninformed party, whereas extrinsic facts are,$^{13}$ or that extrinsic facts are normally the result of a deliberate search, whereas intrinsic facts are often casually acquired. ${ }^{14}$ In addition, scholars argue that the intrinsic/extrinsic distinction cannot adequately explain the results in all of the cases, particularly those where the uninformed party is the purchaser, as opposed to the seller. ${ }^{15}$ Finally, some observers argue that the intrinsic/extrinsic distinction has been replaced in modern jurisprudence with other theories of disclosure duties and is no longer relevant to court decisions concerning the degree of candor required of contracting parties. ${ }^{16}$ We thus predicted that in earlier years courts would be more likely to rule that a duty to disclose existed in cases involving intrinsic information, but that this effect would narrow in significance over time and finally disappear altogether.

\section{The Undisclosed Information Concerned Personal Intentions or Opinions}

Although the distinction between opinion and fact is not always clear, commentators seem to agree that failure to disclose personal opinions or intentions is not actionable. ${ }^{17}$ This rule is sometimes re-

\footnotetext{
${ }^{13}$ See Scheppele, supra note 2, at 128-29; W. Page Keeton, Fraud-Concealment and Non-Disclosure, 15 Tex. L. Rev. 1, 21 (1936).

${ }^{14}$ See Kronman, supra note 1 , at $17-18$ (arguing that market information is typically, though not always, acquired through deliberate search).

${ }^{15}$ See Keeton, supra note 13 , at 21.

${ }^{16}$ See Scheppele, supra note 2, at 128-29.

${ }^{17}$ See, e.g., Morton J. Horwitz, The Transformation of American Law, 1780-1860, at 263 (1977) (stating that misstatements of opinion were not actionable at common law, the rationale being to prevent judicial incursion into the private bargaining process); see also Dalley, Law of Deceit, supra note 2, at 409 (listing reasons for the rule that
} 
ferred to as a distinction between personal and general information, or between individual and common facts. ${ }^{18}$ Gulian Verplanck illustrates the distinction as follows: A director of a large insurance company believes, from his observations and knowledge of the insurance industry and his own institution, that the insurance business is "overdone" and that current premiums are an inadequate compensation for the risks assumed by insurers. ${ }^{19}$ If he sells his insurance stock to a purchaser with less knowledge of the industry than he, the director is under no duty to disclose his opinion (with which other informed parties might reasonably disagree) that the stock is overpriced. ${ }^{20}$ If, on the other hand, the undisclosed information concerns losses in the insurance company that have depleted half its capital (a verifiable fact), disclosure would be required. $^{21}$

statements of opinion are not actionable, including difficulties of proof and the fact that such statements were too common to be reasonably relied on), 418-19 (arguing that statements of intention are not actionable). A long-standing exception to this rule exists: Under the doctrine of promissory fraud, a party commits fraud by entering into a contract without disclosing that she lacks a present intention to perform on the contract. See, e.g., Lazar v. Superior Court, 909 P.2d 981, 985 (Cal. 1996) ("'Promissory fraud' is a subspecies of the action for fraud and deceit. A promise to do something necessarily implies the intention to perform; hence, where a promise is made without such intention, there is an implied misrepresentation of fact that may be actionable fraud."); Paiva v. Vanech Heights Constr. Co., 271 A.2d 69, 71 (Conn. 1970) ("Although the general rule is that a misrepresentation must relate to an existing or past fact, there are exceptions to this rule, one of which is that a promise to do an act in the future, when coupled with a present intent not to fulfil [sic] the promise, is a false representation."); Beers v. Atlas Assurance Co., 253 N.W. 584, 587 (Wis. 1934) ("While there is a division of opinion, the weight of authority sustains a broader rule to the effect that fraud may be predicated upon a promise made with a present intention not to perform the same.").

${ }^{18}$ See, e.g., Gulian C. Verplanck, An Essay on the Doctrine of Contracts: Being An Inquiry How Contracts Are Affected in Law and Morals by Concealment, Error, or Inadequate Price 119-20 (Arno Press 1972) (1825) (distinguishing individual and common facts); Paula J. Dalley, From Horse Trading to Insider Trading: The Historical Antecedents of the Insider Trading Debate, 39 Wm. \& Mary L. Rev. 1289, 132729 (1998) [hereinafter Dalley, Insider Trading] (distinguishing general and personal information).

${ }^{19}$ Verplanck, supra note 18 , at 121 .

${ }^{20}$ Id. at $121-22$.

${ }^{21}$ Id. at 122. Verplanck's hypothetical also could be explained on the grounds that courts distinguish between intrinsic and extrinsic facts, or that the parties lack equal access to information regarding the lost capital, whereas information regarding the general state of the insurance industry is theoretically available to everyone. Similarly, 
Although we predicted that courts are less likely to find that the informed party owed the uninformed party a duty to disclose when the withheld information related to a personal opinion or intention, we also predicted that such cases were relatively rare, given the widespread agreement among commentators that such information is not required to be disclosed. In addition, as regards allegations of a failure to disclose personal opinions, there is a second reason to predict that these sorts of cases are rare. Because most opinions are founded on underlying facts, we predicted that wellpleaded suits generally allege fraudulent nondisclosure of these facts, rather than of the opinion itself. In other words, because plaintiffs (or, more accurately, their counsel) should plead those claims that have some chance of success, we predicted that relatively few cases alleging a failure to disclose a personal opinion would be present in our dataset. Instead, plaintiffs intent on increasing their chances of success should plead a failure to disclose the underlying facts on which the opinion was based.

\section{The Undisclosed Information Related to a Latent Defect}

One of the most common theories employed by commentators to explain the results in nondisclosure cases concerns the difference between latent and patent defects. As with so many of our variables, commentators seem to agree that there is a greater duty to disclose latent, as opposed to patent, defects, but they disagree as to the rationale for the distinction. ${ }^{22}$

In order to distinguish the concept of latent defect from that of unequal access to information, we employ the term "latent defect"

Professor Paula Dalley illustrates the common-law rule regarding the disclosure of personal intentions through the example of a horse trade. Dalley, Insider Trading, supra note 18, at 1328 . In her example, the fact that the horse seller plans to leave town shortly and is therefore willing to accept any price for the horse is personal information that need not be disclosed. Id.

${ }^{22}$ Compare, e.g., Kronman, supra note 1, at 22-25 (arguing that requiring sellers to disclose latent-but not patent-defects is an economically efficient policy because sellers typically acquire information regarding latent defects casually and because requiring the disclosure of obvious defects increases transaction costs), with Scheppele, supra note 2, at 134-38 (arguing that the distinction between latent and patent defects is best justified on the grounds that latent defects are typically inaccessible to one of the parties - generally the buyer). 
narrowly in this Article, as a term of art. Accordingly, as defined here, only property (including slaves) can be subject to a latent defect - the term does not apply to all undisclosed and difficult-toaccess information. ${ }^{23}$ For example, an undisclosed illness or injury affecting a person would not qualify as a latent defect in an application for insurance or employment, but would constitute a latent defect in the sale of a slave. ${ }^{24}$ Similarly, in a stock transaction, the fact that the issuer is about to become the subject of a takeover bid, thus raising the stock price significantly, would not be considered a "defect," although the information is certainly relevant to the transaction and would greatly affect the purchase price. Consistent with the assertions of legal scholars, we predicted that courts are more likely to impose disclosure duties when the withheld information relates to a latent defect.

\section{The Information Concerned a Defect Likely to Cause Bodily Injury or Property Damage}

It has been argued that the law traditionally has taken a stricter view with regard to information that, if disclosed, could prevent the occurrence of bodily injury or property damage, as opposed to information that, if disclosed, would avoid mere economic loss. ${ }^{25}$ The distinction seems defensible from an economic standpoint, as there may be circumstances when it would be inefficient for the law to correct an economic loss of one party (such as in some circumstances when the informed party has expended time and effort to acquire the information). The same efficiency argument cannot be

\footnotetext{
${ }^{23}$ See infra notes $59-60$ and accompanying text (discussing fraudulent silence in slave sales).

${ }^{24}$ Compare Smith v. Rowzee, 10 Ky. (3 A.K. Marsh.) 527, 531 (1821) (sale of diseased slave coded as latent defect), and Huntington v. Brown, 17 La. Ann. 48, 49 (1865) (same), with Leclerc v. Prudential Ins. Co. of Am., 39 A.2d 763, 764 (1944) (illness in applicant for insurance not coded as latent defect). In both cases, however, information regarding the undisclosed injury or illness might be accessible to only one party, meaning that the parties had unequal access to the information.

${ }^{25}$ See Keeton, supra note 13, at 14-17, 36. Apparently, this reasoning dates back at least to the time of St. Thomas Aquinas, who argued that vendors should be required to reveal defects in the good sold if "the defect is of such a nature that it may cause some damage to the buyer." Pothier, supra note 10, I 238, at 144 (criticizing Aquinas's restrictive view of disclosure duties).
} 
made generally with regard to the prevention of bodily injury or property damage.

For example, in older cases, some courts required the disclosure of information concerning the presence of small pox or other dangerous germs, which, if known by the uninformed party, could have prevented the contraction and spread of the disease. ${ }^{26}$ Modern examples may include the duty of tobacco companies to disclose the health risks associated with cigarette smoking ${ }^{27}$ and the duty of sellers of real property to disclose the presence of asbestos or lead paint. ${ }^{28}$ Because this rule seems sensible from a policy perspective

${ }^{26}$ See, e.g., Huset v. J.I. Case Threshing Mach. Co., 120 F. 865, 865 (8th Cir. 1903) ("A manufacturer or vendor, who, without giving notice of its character or qualities, supplies or delivers to another a machine or article which, at the time of delivery, he knows to be imminently dangerous to the life or limbs of any one who may use it for the purpose for which it is intended, is liable to any one who sustains injury from its dangerous condition, whether he has any contractual relations with him or not."); Leech v. Husbands, 152 A. 729, 733 (Del. Super. Ct. 1930) (holding that the landlord's failure to disclose that a residence was "infested with vermin, bugs and disease germs" constituted fraud, although the tenant waived his right to relief by failing to sue within a reasonable time after discovering the defect); Cowen v. Sunderland, 14 N.E. 117, 118 (Mass. 1887) ("It has thus been held that where one lets premises infected with the small-pox, and injury occurred thereby, he was liable if, knowing this danger, he omitted to inform the lessee.").

${ }^{27}$ Congress probably preempted any state common-law duties of cigarette manufacturers to disclose the health risks associated with smoking tobacco with the Federal Cigarette Labeling and Advertising Act of 1965, as amended by the Public Health Cigarette Smoking Act of 1969. See 15 U.S.C. $\$ \S 1331-1340$ (2000). Together, these statutes provide that, "[n]o requirement or prohibition based on smoking and health shall be imposed under Statc law with respect to the advertising or promotion of any cigarettes the packages of which are labeled in conformity with the provisions of this chapter." Id. §1334(b). The Supreme Court has held that these statutes preempt state law claims based on a failure to disclose material health risks to consumers through advertising or promotion. Cipollone v. Liggett Group, Inc., 505 U.S. 504, 524 (1992). In theory, claims based on a failure to disclose through other channels the health risks associated with smoking are not preempted. Cf. Burton v. R.J. Reynolds Tobacco Co., 884 F. Supp. 1515, $1521 \&$ n.4 (D. Kan. 1995) (refusing to dismiss plaintiff's fraud claim alleging that "the defendants knew that use of their products caused cancer and vasculatory disease, yet willfully chose to conceal those facts from the public" and noting that "it is possible that plaintiff can assert viable claims" of fraud at trial).

${ }^{28}$ See Kezer v. Mark Stimson Assocs., 742 A.2d 898, 903 (Me. 1999) (applying a Maine law that requires the disclosure of the existence of all hazardous materials including asbestos and lead-based paint); Stanley J. Levy, Asbestos and the Real Estate Industry: The Legacy of the Magic Mineral, in The Impact of Asbestos on Real Estate 7, 29-30 (1989) (stating that the dangerous qualities of asbestos may create a duty to disclose its known existence). But see Justice v. Anderson County, 955 S.W.2d 613, 617 (Tenn. Ct. App. 1997) (finding that the purchasers of a school building were not 
and can be traced back at least to the fourteenth century, we predicted that, when the failure to disclose information is likely to cause physical injury or property damage, courts are more likely to rule that a duty to disclose exists.

\section{The Information Would Have Updated or Corrected Previously Disclosed Information ${ }^{29}$}

A duty to correct may arise if a statement is false when made even if the speaker believes the information to be correct. If the speaker subsequently discovers that the information earlier disclosed was false, he may have a duty to correct that information.

By contrast, a duty to update may arise in some instances if a statement is correct when made, but later developments subsequently render the statement incorrect or misleading. ${ }^{30}$ The $\mathrm{Re}$ -

entitled to rescind the sales contract on the grounds that the property's vendors - the county and school district - fraudulently concealed the presence of asbestos in the building, when the building was purchased "as is" at a public auction, the transaction was arm's length, there was no fiduciary relationship between the parties, and the presence of asbestos was reasonably discoverable by purchasers).

${ }^{29}$ Although many courts and commentators discussing the common law of nondisclosure do not distinguish between the duty to update and the duty to correct, federal courts and commentators applying or discussing the federal securities laws consider the distinction important, particularly as not all courts recognize a duty to update under the federal securities laws. See Donald C. Langevoort, Half-Truths: Protecting Mistaken Inferences by Investors and Others, 52 Stan. L. Rev. 87, 118 (1999) (noting that the Second and Third Circuits recognize a duty to update "forward looking" information under some circumstances).

The court in Oran $v$. Stafford explained the distinction between the duty to update and the duty to correct well:

The duty to correct exists "when a company makes a historical statement that, at the time made, the company believed to be true, but as revealed by subsequently discovered information actually was not." ... .

The duty to update, in contrast, "concerns statements that, although reasonable at the time made, become misleading when viewed in the context of subsequent events."

Oran v. Stafford, 226 F.3d 275, 286 (2000) (quoting In re Burlington Coat Factory Sec. Litig., 114 F.3d 1410, 1431 (3d Cir. 1997) (citations omitted)).

We coded the duty to update and the duty to correct together, rather than separately, due to the difficulty of distinguishing one from the other, particularly in cases where the court did not distinguish between the two or confused the two issues.

${ }^{30}$ See Edward H. Wilson, Concealment or Silence as a Form of Fraud, and the Relief or Redress Afforded Therefor, Both in Law and in Equity, 5 The Counsellor 230, 236 (1895) ("Where one party has made a material representation which is true at the time, but which subsequently, to his knowledge, but not the knowledge of the other, 
statement (Second) of Torts recognizes both a duty to correct and a duty to update, by stating that a party to a business transaction is under an obligation to disclose "subsequently acquired information that he knows will make untrue or misleading a previous representation that when made was true or believed to be so."31 We predicted that cases involving information that would have updated or corrected previously disclosed information are more likely to result in a finding that the informed party owed the uninformed party a duty to disclose.

\section{B. The Type of Transaction}

Commentators also have asserted that the degree of required disclosure depends on the type of transaction in question. In particular, they have asserted that courts require heightened disclosure in the cases of transactions between parties in a confidential or fiduciary relationship; transactions concerning the acquisition of insurance, surety, or a release from liability; transactions in which the parties have unequal access to information; transactions concerning the transfer of real property; and transactions concerning the sale or transfer of a slave.

\section{A Transaction Between Parties in a Confidential or Fiduciary Relationship}

The most commonly asserted basis for the imposition of a duty to disclose material information is the presence of a fiduciary or confidential relationship between the parties to the transaction. ${ }^{32}$ Technically, confidential relationships (or "relationships of trust and confidence" as they are typically labeled) differ from fiduciary

becomes, through the alteration of circumstances, untrue, it is his imperative duty to communicate to the other information of the change in affairs.").

${ }^{31}$ Restatement (Second) of Torts $\S 551(2)$ (c) (1976).

${ }^{32}$ See, e.g., 1 Story, supra note $10, \$ 308$, at 305 ; see also Bay Colony, Ltd. v. Trendmaker, Inc., 121 F.3d 998, 1004 (5th Cir. 1997) (stating that Texas law recognizes a duty to disclose which supports an action for fraud by nondisclosure only where a fiduciary or confidential relationship exists); Banque Arabe et Internationale D'Investissement v. Md. Nat'l. Bank, 57 F.3d 146, 155 (2d Cir. 1995) (holding that an affirmative duty to disclose arises from the need to complete a partial statement or from a fiduciary or confidential relationship between the parties). 
relationships in that a fiduciary relationship arises out of the position of the parties relative to each other, while a confidential relationship arises from the conduct of the parties or from the nature of the transaction that is the subject of the dispute. ${ }^{33}$ For purposes of this Article, however, the distinction is irrelevant. We hypothesize that both types of relationships lead to greater disclosure requirements than do arms-length relationships, and accordingly, we make no attempt to distinguish fiduciary relationships from those that are merely confidential.

Unfortunately, although the fiduciary character of some relationships is clear-such as principal and agent, corporate officer or director and shareholder, or trustee and beneficiary - the fiduciary or confidential nature of other relationships is not so clear, or might vary from state to state or across the time frame of our study ${ }^{34}$ In fact, courts have purposely failed to provide an exhaustive list of fiduciary relationships, preferring instead loose standards that allow judges to consider the specific facts of each case. ${ }^{35}$ In order to avoid the difficulties and subjective decisions that could lead to errors in coding such cases, we adopted bright-line rules

\footnotetext{
${ }^{33}$ For example, the relationship between two family members may or may not be confidential depending on factors such as whether they typically entrust confidential information to one another or whether they enjoy a congenial relationship. In contrast, because of the status of a trust manager as a fiduciary to the trust beneficiary, the trust manager owes the trust beneficiary a fiduciary duty that cannot be diminished through daily interactions that suggest the relationship is not one of trust and confidence. See George Gleason Bogert, Confidential Relations and Unenforcible Express Trusts, 13 Cornell L.Q. 237, 248 (1928) (discussing the difference between confidential and fiduciary relationships); Richard W. Painter, Kimberly D. Krawiec, \& Cynthia A. Williams, Don't Ask, Just Tell: Insider Trading after United States $v$. O'Hagan, 84 Va. L. Rev. 153, 176-77 nn.101-03 (1998) (same).

${ }^{34}$ A common (but not exhaustive) list of recognized fiduciaries would include the following: executors, guardians, trustees, attorneys, and, to an extent, corporate directors and senior executives. See John C. Coffee, Jr., From Tort to Crime: Some Reflections on the Criminalization of Fiduciary Breaches and the Problematic Line Between Law and Ethics, 19 Am. Crim. L. Rev. 117, 150 (1981).

${ }^{35}$ Id. ("The common law has in fact always defined the term [fiduciary] with deliberate imprecision ....".); see also Harper v. Adametz, 113 A.2d. 136, 139 (Conn. 1955) (stating that the court has purposefully refrained from defining a fiduciary relationship in precise detail that would exclude new situations); Karen E. Boxx, The Durable Power of Attorney's Place in the Family of Fiduciary Relationships, 36 Ga. L. Rev. 1, 15 (2001) ("A clear characterization of fiduciary obligation is elusive and its exact nature is much debated.").
} 
that suit the purposes of our study but might not technically conform to the law.

For example, the traditional common-law rule was that corporate officers and directors owed fiduciary duties only to the corporation itself, or to the shareholders as a unit, and not to the individual shareholders of the corporation. ${ }^{36}$ Accordingly, courts often ruled that officers and directors could trade with shareholders based on material non-public information without disclosing such information. ${ }^{37}$ On the other hand, some courts, often invoking the "special facts" doctrine, refused to permit such transactions by corporate officers and directors without full disclosure. ${ }^{38}$ Because fiduciary obligations to individual shareholders were not recognized at this time, some commentators have used these cases as evidence

\footnotetext{
${ }^{36}$ Allen v. Curtis, 26 Conn. 456, 461 (1857) ("[T]he directors of the bank are the agents of the bank. The bank is the only principal, and there is no such trust for, or relation to, a stockholder as has been claimed by the plaintiff."); Bd. of Comm'rs of Tippecanoe County v. Reynolds, 44 1nd. 509, 513-16 (1873) (stating that directors owe the shareliolders as a unit a fiduciary duty when dealing with the corporation's business or property, but that no such duty is owed by an officer or director to an individual shareholder when transacting for the purchase or sale of stock in the corporation); Smith v. Hurd, 53 Mass. (12 Met.) 371, 384 (1847) ("There is no legal privity, relation, or immediate connexion, between the holders of shares in a bank, in their individual capacity, on the one side, and tle directors of the bank on the other. The directors are not the bailees, the factors, agents or trustees of such individual stockholders.").

${ }^{37}$ Freeman v. Decio, 584 F.2d 186, 191 (7th Cir. 1978) ("Absent fraud, the traditional common law approach has been to permit officers and directors of corporations to trade in their corporation's securities free from liability to other traders for failing to disclose inside information."); Adams v. Mid-West Chevrolet Corp., 179 P.2d 147, 156 (Okla. 1946) ("The general rule is that officers and directors . . cannot deal with the property of the corporation for their own personal benefit or advantage. But this duty does not extend to the outstanding stock of the corporation for the reason that such stock is the individual property of the respective stockliolders and not in any sense the corporation's property.").

${ }^{38}$ Strong v. Repide, 213 U.S. 419, 431 (1909) ("That the defendant was a director of the corporation is but one of the facts upon which the liability is asserted, the existence of all the others in addition making such a combination as rendered it the plain duty of the defendant to speak."). Tloose other facts included that Repide owned seventy-five percent of the stock of the company, was administrator general of the company, was the chief negotiator for the company in talks that eventually led to the sale of all of the company's property, and was in reality acting as an agent for all of the other shareholders in such negotiations. Id. at 431-32; see also Freeman, 584 F.2d at 191 ("A few jurisdictions now require disclosure where certain 'special facts' exist, and some even impose a strict fiduciary duty on the insider vis-à-vis the selling shareholder.").
} 
that courts apply an equality of access doctrine to determine when disclosure will be required. ${ }^{39}$

We believe, however, that such cases are better understood as a precursor to today's doctrine of officer and director fiduciary duties rather than as evidence of a broad insistence by courts that parties to transactions have equal access to information. We thus coded these cases as fiduciary duty cases (as well as unequal access cases in most instances), despite the fact that the court might not have invoked this rationale and might even have specifically rejected it.

Similarly, whether some relationships are confidential in nature varies from state to state or with the specific circumstances of the relationship. An examination of the law governing marital relations helps to illustrate the point. Some states consider marriage an inherently fiduciary relationship while others hold that marital relations might or might not be confidential, depending on the circumstances. $^{40}$ Some states hold that a fiduciary or confidential relationship automatically begins with engagement while others do not. ${ }^{41}$ Courts also differ in the extent to which they treat married but separated persons as parties to a confidential or fiduciary relationship. ${ }^{42}$

\footnotetext{
${ }^{39}$ See, e.g., Strong, 213 U.S. at 433-34 (holding that agents of Repide, the chief shareholder, and the director of the Philippine Sugar Estates Development Company should have disclosed to prospective sellers of the company's shares that they were acting on behalf of Repide, who was also the company's chief negotiator for a U.S. government contract); Scheppele, supra note 2, at 113-14 (arguing that the Court's ruling in Strong is explainable on equal access grounds, and not on fiduciary duty grounds, because the court explicitly rejected the proposition that corporate directors owe shareholders special disclosure obligations).

${ }^{40}$ Compare, e.g., United States v. Chestman, 947 F.2d 551, 568 (2d Cir. 1991) (noting that marriage is not per se a fiduciary relationship), with DeLorean v. DeLorean, 511 A.2d 1257, 1262 (N.J. Super. Ct. Ch. Div. 1986) (noting that marriage is a fiduciary relationship).

${ }^{41}$ Compare, e.g., In re Marriage of Sokolowski, 597 N.E.2d 675, 680 (Ill. App. Ct. 1992) (noting that a confidential relationship begins at engagement under Illinois law), and Lightman v. Magid, 394 S.W.2d 151, 156 (Tenn. Ct. App. 1965) (noting that a confidential relationship ordinarily exists at engagement), with Handley $v$. Handley, 248 P.2d 59, 62 (Cal. Dist. Ct. App. 1952) (holding that the presumption of a confidential relationship did not exist prior to marriage).

${ }^{42}$ Compare, e.g., Harroff v. Harroff, 398 S.E.2d 340, 343 (N.C. Ct. App. 1990) (holding that married persons owe each other fiduciary duties while negotiating a separation agreement), with In re Marriage of Auble, 866 P.2d 1239, 1244 (Or. Ct. App.
} 
To avoid the daunting task of mastering the intricacies of the law of confidential relations in all fifty states, as well as the necessity of subjective judgment calls concerning whether the circumstances of a particular relationship make it confidential, we adopted brightline rules that reflected the weight of authority and applied them across all jurisdictions. For example, we treated engaged persons negotiating a prenuptial agreement as parties to a confidential relationship in all 50 states, despite the fact that this is not the law in all jurisdictions under all circumstances. This bright-line approach did not trouble us, given our hypothesis that, despite asserted differences across jurisdictions in the law of confidential relations, as a general matter, courts impose a heavier disclosure obligation in cases where the relation between the parties could be considered fiduciary or confidential, such as a familial or marital relationship, than they do when the parties share a merely arms-length relationship. We thus predicted a significant, positive relationship between the likelihood of the court imposing disclosure duties and the existence of a fiduciary or confidential relationship.

\section{The Transaction Concerned Insurance, Surety, or a Release from Liability}

Professor W. Page Keeton described this theory best: "In releases, in contracts of insurance, and in contracts of suretyship, practically all facts affecting the matter must be disclosed." 43 The most commonly asserted rationale for this rule, particularly as regards insurance, is that the insured likely has knowledge affecting the contract that is unavailable to the insurance underwriter. ${ }^{44}$

1993) (holding that married persons living apart may not owe each other fiduciary duties in the negotiation of a separation agreement).

${ }^{43}$ Keeton, supra note 13 , at 36; Wilson, supra note 30 , at 231 . But see Scheppele, supra note 2, at 147-48 (arguing that when the insurer and insured have equal access to information, disclosure is not required).

${ }^{44}$ Scheppele, supra note 2 , at $146-48$; Verplanck, supra note 18 , at $37-38$ ("The insured being the party from whom, in most cases, the underwriter obtains the special facts upon which the calculation of the risk is settled .... Every fact within his knowledge, regarding which ignorance or mistake might possibly induce the underwriter to compute his risk upon an incorrect basis ... is considered in law as a material fact, and misrepresentation or suppression of it avoids the policy."). But see Kronman, supra note 1, at 26-27 (explaining the rule that health or life insurance applicants owe the 
Some modern commentators have urged the abolition of the rule of full disclosure in insurance contracts on the grounds that the rule originated in the context of maritime insurance, when vessels were typically insured once they were already at sea and could not be inspected. ${ }^{45}$ Accordingly, they argue that such rules have no place in modern insurance practice, in which the insurance company typically can and does conduct a thorough inspection of the insured property or person. ${ }^{46}$ Nonetheless, we predicted that courts are more likely to find a duty to disclose when the transaction concerns the acquisition of insurance, surety, or a release from liability.

\section{The Transaction Was One in Which the Parties Had Unequal Access to Information}

One of the most lasting, if controversial, theories seeking to explain why courts require disclosure of all material facts in some transactions but not others is the theory that courts will require disclosure whenever the parties have unequal access to information (the "equality of access theory"). ${ }^{47}$ Professor Kim Lane Scheppele has elegantly defined equal access in terms of both structural equality and equality of aptitude. For example, she states that "[t]wo actors will be said to have equal access to information if they (1) have equal probabilities of finding the information if they

insurer a duty of full candor on the grounds that information regarding the health of the applicant is nearly always casually acquired).

${ }^{45}$ See, e.g., Bertram Harnett, The Doctrine of Concealment: A Remnant in the Law of Insurance, 15 Law \& Contemp. Probs. 391, 398-99, 407-10, 413-14 (1950).

${ }^{46}$ Id. at $407-10,413-14$.

${ }^{47}$ Carter v. Boehm, (1766) 97 Eng. Rep. 1162, 1164 (K.B.) ("[E]ither party may be innocently silent, as to grounds open to both, to exercise their judgment upon."); Jenkins v. McCormick, 339 P.2d 8, 11 (Kan. 1959) ("There is much authority to the effect that if one party to a contract or transaction has superior knowledge, or knowledge which is not within the fair and reasonable reach of the other party and which he could not discover by the exercise of reasonable diligence, or means of knowledge which are not open to both parties alike, he is under a legal obligation to speak." (quoting 23 Am. Jur. Fraud and Deceit $\$ 80$ (1940)); Victor Brudney, Insiders, Outsiders, and Informational Advantages Under the Federal Securities Laws, 93 Harv. L. Rev. 322, 354-55 (1979) (defiming equality of access as an informational advantage that cannot be overcome legally by the uninformed party, regardless of her diligence or monetary resources); Wilson, supra note 30, at 234 ("[T]he common law imposes no duty of disclosure where the facts suppressed are equally accessible to both parties to the transaction."). 
put in the same level of effort and (2) are capable of making this equivalent level of effort." ${ }^{, 48}$

People most often have different probabilities of information detection because of structural inequality - in other words, they "have structurally unequal access to knowledge.", In contrast, when two people are unable to expend the same level of effort in information production, it is most often because one does not even realize that the information might exist, or is too lacking in intellectual capability or social knowledge to compete with more sophisticated parties. ${ }^{50}$

Relying on Laidlaw to underpin her theory, Professor Scheppele points to Chief Justice Marshall's dictum that "[i]t would be difficult to circumscribe the contrary doctrine [that is, the doctrine that disclosure is required] within proper limits, where the means of intelligence are equally accessible to both parties"51 to develop an argument that the case outcome can be explained by the fact that the parties had equal access to information. This assumption might seem surprising, given the clear evidence that, due to Organ's special connection to the only three people in New Orleans with knowledge of the end of the war, Laidlaw could not have discovered the information without expending considerably more effort than Organ. Scheppele argues, however, that Organ's discovery of the information was purely fortuitous - Laidlaw was just as likely as Organ to have a partner with a brother aboard the British fleet who came ashore during the night with news that the war had ended. ${ }^{52}$

Despite Professor Scheppele's innovative attempts to clarify the equality of access theory, it remains extraordinarily open-ended and subjective, leading many critics, including one of the present authors, to dismiss the test as providing no meaningful guidance for

\footnotetext{
${ }^{48}$ Scheppele, supra note 2 , at 120 .

${ }^{49}$ Id.

${ }^{50}$ Id. at 121.

${ }^{51}$ Laidlaw, 15 U.S. (2 Wheat.) at 195.

${ }^{52}$ Scheppele, supra note 2, at 122 ("It seems that Organ got his information through a friend who had a brother in the know. Laidlaw's agent, if he had had the same fortune, also could have got the information this way.").
} 
courts. ${ }^{53}$ Needless to say, reasonable minds can wildly differ on what constitutes equal access, and coding for a factor so susceptible to personal interpretation was difficult.

Nonetheless, we attempted to address the problem by laying down bright-line rules. Most importantly, in contrast to Professor Scheppele, we defined access as purely structural. Even gross differences in education or knowledge did not impact our determination of whether equality of access was lacking. Instead, we dealt with such differences by including a separate code for parties who are illiterate, elderly, severely ill, or extraordinarily mentally deficient in some way (although still competent to contract).$^{54}$

Furthermore, we did not, as some commentators might, automatically code purchasers and sellers of real or personal property as having unequal access to information. Instead, if a casual inspection of the property would have revealed the undisclosed information, then we concluded that the parties had equal access to the information in question, despite the fact that purchasers must have sellers' permission before inspecting the property. We felt that this definition was reasonable, given the ease with which the purchaser could request and execute such an inspection, and the suspicion that should arise in the purchaser's mind if the seller refuses the request. Based on the work of Professor Scheppele and other equality of access advocates, we predicted that courts are more likely to impose disclosure duties when the parties have unequal access to the withheld information.

${ }^{53}$ For example, one of the present authors has argued previously that, because both individual aptitude and structural access vary across the population in relation to wealth and education, no two people are ever truly equal. Instead, access is a continuum on which cases of clear inequality or relative equality can be identified at the extremes, but that none of the definitions endorsed by the equality of access advocates gives meaningful guidance as to where to draw the line in the large majority of cases, which fall in the middle of the continuum. Kimberly D. Krawiec, Fairness, Efficiency \& Insider Trading: Deconstructing the Coin of the Realm in the Information Age, 95 Nw. U. L. Rev. 443 (2001); see also Ian Ayres \& Stephen Choi, Internalizing Outsider Trading, 101 Mich. L. Rev. 313, 314-21 (2002) (raising a similar argument).

${ }^{54}$ See infra Section I.D.3 (discussing this variable). 


\section{The Transaction Concerned the Transfer of Real Property}

It has been argued by some commentators that courts impose a greater duty of disclosure with regard to the transfer of real property than in other types of transactions, a rule that apparently dates back to the Roman civil law. ${ }^{55}$ At common law, this rule might have been the result of implied warranties of habitability and title. ${ }^{56}$ In many states today, much of the common law in this area has been superseded by statutes that mandate high levels of disclosure in real estate transactions, particularly residential ones. We predicted that courts are more likely to impose a duty to disclose when the transaction concerns the transfer of real property.

\section{The Transaction Concerned the Transfer of a Slave}

Slavery cases of all kinds have understandably generated significant interest not only in the legal literature, but in history and economics as well. ${ }^{57}$ Although one might expect that courts would formulate different disclosure rules in slave sale cases than in other sale of goods cases, in recognition of the fact that the property at issue is a human being, a review of the cases should quickly disabuse the reader of that notion.

For example, courts could have used the rule that bargaining parties have a duty to disclose defects likely to cause personal injury as a basis for imposing a duty to disclose any illness or injury

${ }^{55}$ See, e.g., Cicero, On Moral Obligation (De Oficiis) II 65, at 159 (John Higginbotham trans., Univ. of Calif. Press 1967) ("As far as estates are concerned, it is laid down in our civil law that all faults known to the seller be declared at the time of the sale."). See generally John V. Orth, Sale of Defective Houses, 6 Green Bag 163 (2003) (discussing the common law of disclosure in connection with the sale of real property).

${ }^{56}$ As to title, see Pothier, supra note 10 , II 240 , at 145 (noting that the vendor must declare "that the thing does not belong to him; that it does not belong to him irrevocably; or that it is subject to certain charges, annuities (rentes) [sic], or special hypothecations").

${ }^{57}$ See, e.g., 1 Judicial Cases concerning American Slavery and the Negro (Helen T. Catterall ed., William S. Hein \& Co. 1998) (1926); Judith Kelleher Schafer, Slavery, the Civil Law, and the Supreme Court of Louisiana (1994); Andrew Fede, Legal Protection for Slave Buyers in the U.S. South: A Caveat Concerning Caveat Emptor, 31 Am. J. Legal Hist. 322 (1987); Mark Tushnet, New Histories of the Private Law of Slavery, 18 Cardozo L. Rev. 301 (1996); Jenny B. Wahl, The Jurisprudence of American Slave Sales, 56 J. Econ. Hist. 143 (1996). 
in a slave, the rationale being that lack of disclosure prevents the purchaser from seeking medical attention for the slave. Instead, however, courts of the era deciding disclosure issues seem to have treated slaves much like any other personal property. ${ }^{58}$

This is not to say, however, that special disclosure rules did not arise in connection with slavery cases. In fact, economic and legal historians have argued that, although the southern states generally observed a rule of strict caveat emptor much more frequently than did the northeastern states, southern states attempted to regulate the slavery market because of the importance of the slave trade to the southern economy, in part by imposing disclosure duties on parties to a slave sale. ${ }^{59}$ Interestingly, this rule too dates back to Roman law. ${ }^{60}$ We predicted that courts are more likely to find that the informed party has a duty to disclose when the transaction involves the sale of a slave.

\section{How the Information Was Acquired}

Many commentators have argued that the method by which the undisclosed information was acquired has an impact on whether courts require disclosure of the information. Specifically, it has been asserted that courts more frequently require the disclosure of

\footnotetext{
${ }^{58}$ In fact, the argument that illness or injury in a slave falls within the wellrecognized exception for disclosures of defects likely to cause bodily injury was not raised in any of the cases in our dataset, presumably because of the deeply ingrained notion among many southerners of that era (including judges and counsel in the cases) that the southern legal system treats slaves as goods, rather than as individuals whose well-being should be protected by the legal system. See Wahl, supra note 57, at $146 \mathrm{n} .7$ (referring to livestock sales as slave sales' "closest relative").

${ }^{59}$ See, e.g., Fede, supra note 57 (arguing that slave sales were more heavily policed by the courts, which imposed protections such as warranties of titles and soundness, foreshadowing the development of the U.C.C.); Wahl, supra note 57, at 146-49 (arguing that southern courts imposed higher disclosure obligations in slave sales than in other sales transactions). But see Dalley, Law of Deceit, supra note 2, at 430 (finding less protection of buyers against fraud in slave cases than in some other types of cases, such as those involving land, horses, and corporate securities).

${ }^{60}$ Cicero, supra note 55, II 71, at 161 ("It is not only in the sphere of real estate that civil law, which is based on the natural law, condemns trickery and fraud, but also in the case of slave-purchase the buyer is protected by law against deception. Indeed an edict of the aediles lays down that if the seller knows that the slave is a weakling, a runaway or a thief, he inust (except in the case of an inherited slave) declare it.").
} 
casually acquired information and information acquired through illegal or tortious means.

\section{The Information Was Casually, as Opposed to Deliberately, Acquired}

That the law should reward those who expend time and effort to acquire information by permitting them to reap the benefits of bargaining with others without revealing that information is one of the earliest theories offered by legal commentators to explain the law of fraudulent silence. In De Officiis, Cicero constructs a hypothetical in which a merchant sails to Rhodes from Alexandria with a shipment of corn during a time of great famine in Rhodes. ${ }^{61}$ The merchant knows that other ships have set sail from Alexandria to Rhodes with enough corn to alleviate the famine and will arrive shortly. In an imaginary dialogue, the Stoic philosophers Antipater and Diogenes debate whether the merchant should be required to reveal all that he knows. ${ }^{62}$

Discussing the hypothetical in his 1761 Treatise on Obligations, the French legal theorist R.J. Pothier agrees with Cicero's conclusion that the merchant should disclose his secret information. He acknowledges, however, that the majority of other writers on the subject have considered the merchant's profits to be made by nondisclosure "not an unjust profit; but a just reward for the diligence which enabled him to arrive the first, and for the risk which he ran of losing his merchandise, if any of the accidents, to which he was exposed, should have prevented his arrival at the time." ${ }^{, 63}$ Similarly, writing in 1936, Professor W. Page Keeton argued that the manner in which the informed party acquired his information is relevant to courts' determinations of disclosure duties, noting that, "[t]he in-

\footnotetext{
${ }^{61}$ Id. II 50 , at $153-54$.

${ }^{62}$ Id. TII 51-53, at 154. In the hypothetical, Antipater argues that "he should tell everything, so that the buyer can be just as much in possession of the facts as the seller." Id. II 51, at 154. Diogenes responds that "these bonds [of social unity] are not such that a man may not have anything to call his own. If that is so, there is not even any selling to be done, only giving." Id. \$1 53, at 154.

${ }^{63}$ Pothier, supra note 10, II 242, at 148. Although he agrees with Cicero's conclusions, Pothier also notes, "[t]he decision of Cicero meets with much difficulty even in the forum of conscience. The greater number of those who have written upon natural law have regarded it as going too far." Id.
} 
formation might have been acquired as the result of his bringing to bear a superior knowledge, intelligence, skill or technical judgment," or "it might have been acquired by mere chance.",

Professor Anthony Kronman elaborated on this theory by arguing that the seemingly inconsistent results in similar cases involving the nondisclosure of relevant facts could be reconciled by noting that when nondisclosure is permitted, the knowledge involved is typically the result of a deliberate search. ${ }^{65}$ Kronman argued that a rule permitting silence in such instances was a sensible economic policy, as it represented the only effective means of providing incentives for the production of costly information that would not normally be discovered, absent a deliberate search. ${ }^{66}$ Although Kronman conceded that Organ's information appeared to be acquired fortuitously, rather than deliberately (recall that Organ's business partner's brother had been at sea with the British fleet and arrived in New Orleans during the middle of the night, tipping Organ about the soon-to-be-disclosed news of the war's end), he believed that this did not undermine his theory. Instead, Kronman argued that Marshall's decision resulted from an attempt to lay down a blanket rule concerning the disclosure of market information, which is typically, though not always, deliberately acquired. ${ }^{67}$

Like Professor Kronman, we define "deliberately acquired information" as "information whose acquisition entails costs which would not have been incurred but for the likelihood, however

\footnotetext{
${ }^{64}$ Keeton, supra note 13, at 25. See also Hays v. Meyers, 107 S.W. 287, 288 (Ky. 1908) (stating that a party has no duty to disclose "the superior knowledge of property he desires to purchase that has been acquired by skill, energy, vigilance, and other legitimate means" and stating further that "[i]f any other rule were adopted, it would have a depressing tendency on trade and commerce by removing the incentive to speculation and profit that lies at the foundation of almost every business venture"); Wilson, supra note 30 , at 231 ("[T]he common law ... declares that men should as a general rule take care of themselves, and that some incentive to diligence and discretion in their affairs should be afforded, by giving them, in ordinary transactions, the benefit of their industry and discernment.").

${ }^{65}$ Kronman, supra note 1, at 9. Although Professor Kronman limited his theory to "socially productive information," we find this distinction unnecessary to test his hypothesis. In practice, it is difficult to conceive of examples of failures to disclose socially unproductive information that would result in demonstrable damages to the plaintiff, thus resulting in litigation and written judicial opinions.

${ }^{66}$ Id.

${ }^{67}$ See infra note 73 and accompanying text.
} 
great, that the information in question would actually be produced." The costs of acquiring such information might include not only direct search costs, but also the costs of developing any needed expertise, such as, for example, the costs of attending business school or studying the values of art or antiques. ${ }^{69}$

Casually acquired information, by contrast, is information the acquisition of which entails costs that would have been incurred even if the information were not forthcoming. ${ }^{70}$ To illustrate, a businessman who overhears information while riding on a bus has acquired the information casually, except in the unlikely event that he rides buses specifically for that purpose. ${ }^{71}$

Professor Kronman recognized that, although analytically useful, the determination as to whether any given piece of information was deliberately or casually acquired in any instance was a difficult one for courts to make in the real world. ${ }^{72}$ Accordingly, he argued that, rather than make case-by-case determinations as to the manner of information acquisition, courts should adopt blanket rules regarding whether the kind of information involved in a particular class of case (say, real estate purchases, or the sale of a good with a latent defect) was generally more likely to be generated deliberately or casually, as doing so would be more efficient. ${ }^{73}$

In contrast to using Professor Kronman's classification of the case in question, we judged whether information was acquired casually or deliberately based on the facts of the case. We did this for several reasons. First, although Kronman discussed general rules as to the likely means of information acquisition in certain classes of cases (for example, market information, the knowledge of purchasers and sellers of real property, and information relating to the health of an applicant for health or life insurance), he did not lay down general classifications for every possible range of facts. Accordingly, any attempt to apply blanket rules would have

\footnotetext{
${ }^{68}$ Kronman, supra note 1 , at 13.

${ }^{69} \mathrm{Id}$.

${ }^{70} \mathrm{Id}$.

${ }^{71}$ Id. at 13 \& n. 38

${ }^{n}$ Id. at 13.

${ }^{73} \mathrm{Id}$. at $17-18$.
} 
required significant fact-specific inquiry to create such rules for all classes of cases contained in our sample set.

Second, coding individual cases on their own facts enabled us to test not only the robustness of the deliberately/casually acquired distinction, but also Professor Kronman's empirical claims as to the likely mode of information acquisition in those classes of cases for which he suggested blanket rules. In other words, coding in this manner permitted us to judge, for example, whether extrinsic information is typically acquired deliberately, as contended by Kronman.

Other commentators disagree that the deliberately/casually acquired information distinction is a meaningful predictor of the outcomes of fraudulent silence cases. ${ }^{74}$ Our own view embarking on this project was that, regardless of whether Professor Kronman's theory was sound from an economic policy perspective, it was difficult to apply in practice and had not been embraced by courts outside the Seventh Circuit. ${ }^{75}$ Despite these critiques of Kronman's conjecture, we predicted a significant relationship between whether the information was casually acquired and the likelihood that a court would impose disclosure duties.

\section{The Information Was Acquired Through Illegal or Tortious Means}

Courts and commentators often take the position that information acquired by illegal or tortious means must be disclosed to a contracting counterparty. ${ }^{76}$ A standard example is that if $A$ trespasses upon $B$ 's land and while there conducts a test and deter-

\footnotetext{
${ }^{74}$ See, e.g., DeMott, supra note 2, at 68-69, 85; Scheppele, supra note 2, at 124-26.

${ }^{75}$ The influence of Judges Easterbrook and Posner in the Seventh Circuit, their embrace of law and economics principles, and their familiarity with academic theory led us to this hypothesis. See, e.g., FDIC v. W.R. Grace \& Co., 877 F.2d 614, 619 (7th Cir. 1989) (Posner, J.) (opining that a seller had a duty to disclose material information obtained "without substantial investment ... which the buyer would find either impossible or very costly to discover himself").

${ }^{76}$ See, e.g., Mallon Oil v. Brown/Edwards Assoc., 965 P.2d 105, 111-12 (Colo. 1998); George Spencer Bower, The Law of Actionable Misrepresentation 107 (Sir Alexander Kingcome Turner ed., 3d ed. 1974); Keeton, supra note 13, at 25-26; Donna M. Nagy, Reframing the Misappropriation Theory of Insider Trading Liability: A PostO'Hagan Suggestion, 59 Ohio St. L.J. 1223, 1290-92 (1998).
} 
mines that oil is located on the land, if $A$ subsequently purchases the land from $B$ without disclosing to $B$ the presence of oil on his land, $B$ might have a right to rescind the contract. ${ }^{77}$ We predicted that courts are significantly more likely to find a duty to disclose when the information is acquired by illegal or tortious means.

\section{Characteristics of the Uninformed Party}

Commentators frequently assert that court rulings are influenced by certain characteristics of the uninformed party. We hypothesized that courts require disclosure more frequently when the uninformed party is a buyer or lessee; when the uninformed party is female; and when the uninformed party is sick, disabled, illiterate, elderly, or otherwise severely disadvantaged in the bargaining relationship, although still competent to contract.

\section{The Uninformed Party Was the Buyer or Lessee}

Commentators seem to agree that sellers have a higher obligation to disclose information affecting the value of the transaction than do buyers, although they disagree as to why courts make this distinction. ${ }^{78}$ Professor Keeton explains the rule as follows: "The buyer is not ordinarily expected to disclose information greatly af-

${ }^{77}$ Keeton, supra note 13 , at 26 ; see also Restatement (Second) of Contracts $\$ 161$ cmt. d, illus. 11 (1979) (stating that information acquired through trespass must be disclosed).

${ }^{78}$ See, e.g., Pothier, supra note 10 , III $294-98$, at $180-82$ (stating that vendees have lesser disclosure obligations than vendors because the vendor ought to be aware of the value of what he sells); Scheppele, supra note 2, at 130-33 (arguing that sellers have greater disclosure duties than purchasers because sellers are more likely to have access to the information in question); DeMott, supra note 2, at 76 ("[B]uyers in many settings are able to withhold with impunity information comparable to information that a seller is obliged to disclose."); Wilham B. Goldfarb, Fraud and Nondisclosure in the Vendor-Purchaser Relation, 8 W. Res. L. Rev. 5, 26 (1956) (arguing that sellers have disclosure duties that exceed those of buyers); Kronman, supra note 1, at 22-23 (stating that buyers in a real estate context have lesser disclosure obligations than sellers because buyers are likely to acquire their information deliberately, whereas sellers are more likely to acquire their information casually); Andrew Kull, Unilateral Mistake: The Baseball Card Case, 70 Wash. U. L.Q. 57, 62 \& n.7 (1992) (arguing that sellers are more often found to have a duty to disclose material information unknown to the buyer because sellers are subject to implied warranties, whereas buyers are not). 
fecting the value of the property which is the subject-matter of the sale, whereas the seller is expected to disclose defects in the property sold which greatly decrease the value of the property." ${ }^{, 79}$

Given this widespread agreement among commentators, we predicted that courts are significantly more likely to impose disclosure duties when the uninformed party is the buyer.

\section{The Uninformed Party Was Female}

Historically, courts and legislatures have used a variety of theories to limit the rights of women to contract freely. For example, in the early twentieth century, courts upheld laws designed to improve working conditions for women against challenges based on interference with the freedom of contract-challenges that had been used successfully to invalidate similar laws that applied to men. ${ }^{80}$

Sometimes, the limitations on women's freedom of contract are explicit, as they were under the doctrine of coverture, which treated the family as a unit and the husband as the head of that unit. As a result of coverture, married women were not permitted to enter into contracts or sue or be sued in court. ${ }^{81}$

\footnotetext{
${ }^{79}$ Keeton, supra note 13 , at $35-36$.

${ }^{80}$ Compare, e.g., Lochner v. New York, 198 U.S. 45, 64 (1905) (holding unconstitutional a state law regulating working hours), with West Coast Hotel Co. v. Parrish, 300 U.S. 379, 400 (1937) (upholding a Washington state statute setting mimimum wages for women only); see also Muller v. Oregon, 208 U.S. 412, 416 (1908) (upholding an Oregon statute establishing maximum working hours for women, but not for men); Commonwealth v. Hamilton Mfg. Co., 120 Mass. 383, 385 (1876) (upholding a Massachusetts statute prohibiting the employment of women and persons under the age of eighteen in any manufacturing establishment for more than sixty hours per week). But see Children's Hosp. v. Adkins, 284 F. 613, 618 (D.C. Cir. 1922) (invalidating a District of Columbia law settimg minimum wages for women but not for men); Ritchie v. People, 40 N.E. 454, 462 (Ill. 1895) (invalidating an Illinois law limiting the working hours of women).

${ }^{81}$ See generally Judith Resnik, Categorical Federahism: Jurisdiction, Gender, and the Globe, 111 Yale L.J. 619, 636 (2001) (discussing the law of coverture); Reva B. Siegel, She the People: The Nineteenth Amendment, Sex Equality, Federalism, and the Family, 115 Harv. L. Rev. 947, 982-83 (2002) (same). In theory at least, restrictions on women's rights to contract under the doctrine of coverture were abolished during the nineteenth century, with the widespread passage of married women's property acts. Id. at 983 ("It is often said that the married women's property acts abolished the common law of coverture in the nineteenth century - a legal fiction if ever there was one. Even the briefest look at antisuffrage discourse reveals that core con-
} 
Other limitations on women's freedom of contract are more subtle, as when women, due to their "delicate" nature or a perceived need to protect them from their own bad bargains, are permitted to rescind their contracts based on protective doctrines such as fraud, duress, or unconscionability, when the same contract would have been enforced against a man. ${ }^{82}$ We hypothesized, therefore, that these gendered notions might have found their way into the law of fraudulent silence, especially in older cases, and predicted that a court is more likely to find a duty to disclose secret information when the uninformed party is female than when the uninformed party is male.

\section{The Uninformed Party Was Sick, Disabled, Illiterate, or Elderly, Though Competent to Contract}

It has been argued that, in the law of fraudulent silence, as elsewhere, courts often rule in favor of sympathetic plaintiffs. ${ }^{83}$ Accordingly, courts might impose disclosure duties more readily when the uninformed party is competent to contract, but is sick, disabled, illiterate, elderly, or extraordinarily mentally deficient in some way. Our goal was to identify contracting parties who even the most

cepts of coverture were a vibrant part of American legal culture well into the twenticth century and shaped public as well as private law.").

${ }^{82}$ See, e.g., Mary Joe Frug, Re-Reading Contracts: A Feminist Analysis of a Contracts Casebook, 34 Am. U. L. Rev. 1065, 1085-86 (1985) (arguing that, in Jackson v. Seymour, the court allowed Lucy Jackson to rescind a contract for the sale of land to her brother because of "gendered ideas" about the vulnerability and financial dependence of widows, rather than because of the confidential nature of their relationship); Debora L. Threedy, Feminists \& Contract Doctrine, 32 Ind. L. Rev. 1247, 1262 (1999) (stating that, "[m]any contract doctrines are paternalistic in the sense of protecting the 'weaker' or disadvantaged party: concealment, misrepresentation, unilateral mistake, undue influence, duress, unconscionability, minority, and lack of capacity all could be said to have a protectionist cast," and noting further that, "[f]eminists have just begun to question whether paternalistic doctrines like unconscionability help or harm women"). But see Margo Schlanger, Injured Women before Common Law Courts, 1860-1930, 21 Harv. Women's L.J. 79, 140 (1998) (finding that courts fairly "treated gender as an important factor in assessing appropriate standards of care, where perceived gender difference was highlighted" in tort cases).

${ }^{83} \mathrm{Cf}$. DeMott, supra note 2, at 97 ("To an unusual degree, judicial opinions in [fraudulent silence] cases ... personalize the parties."); Strudler, supra note 4, at 340 (arguing that nondisclosure law should "pay attention to the moral drama that occurs in bargaining and to the sources of individual negotiators' grievances about exploitation, deception, and betrayal"). 
conservative courts might readily consider easy targets in need of protection from unscrupulous predators. We predicted, therefore, that courts are significantly more likely to impose a duty to disclose when the uninformed party is sick, disabled, elderly, or illiterate.

\section{E. Behavior of the Informed Party}

Just as the characteristics of the uninformed party might impact court rulings, the informed party's behavior might influence court decisions regarding the need for disclosure in any given transaction. Specifically, when the informed party has "behaved badly," courts might be more likely to punish or discourage such behavior through the imposition of disclosure duties that deprive the informed party of the opportunity to legally profit from her secret information. Accordingly, we examined two types of bad behavior by the informed party: affirmative misrepresentations or half-truths that accompany the undisclosed information, and active concealment of the undisclosed information.

\section{The Informed Party Made Affirmative Misrepresentations or Half-Truths}

Fraudulent silence claims often form one part of a larger claim in which other wrongs are alleged, such as affirmative misrepresentations or half-truths. Although technically courts should rule on each count of the complaint separately and should not allow a finding that the informed party intentionally misrepresented one fact to impact the court's finding on liability for a different, undisclosed fact, ${ }^{84}$ we believe that courts are often swayed by a general pattern of bad conduct on the part of the informed party. ${ }^{85}$ Accordingly, we would expect to see disclosure required more often when the in-

\footnotetext{
${ }^{84}$ This is the case unless, of course, the informed party's lies somehow prevented the uninformed party from learning the truth.

${ }^{85}$ Wilson, supra note 30 , at 234 ("'If a word ... if a single word, be dropped which tends to mislead the vendor' it will vitiate the contract. Thus it is, that in the mass of cases in which concealment or fraudulent silence appears, there is also present this misrepresentation ...." (quoting Turner v. Harvey, (1821) 37 Eng. Rep. 814, 818 (Ch. D.))).
} 
formed party also made affirmative misrepresentations or halftruths than when the informed party was truly silent.

A half-truth is a statement that, although technically accurate, is nonetheless misleading in some way. ${ }^{86}$ As stated in the Restatement (Second) of Torts, "[a] representation stating the truth so far as it goes but which the maker knows or believes to be materially misleading because of his failure to state additional or qualifying matter is a fraudulent misrepresentation." ${ }^{17}$

Similarly, the Restatement (Second) of Contracts states that "[a] statement inay be true with respect to the facts stated, but may fail to include qualifying matter necessary to prevent the implication of an assertion that is false with respect to other facts. ${ }^{188}$ To illustrate, the Restatement (Second) of Contracts notes that a true statement that an event has recently occurred might nonetheless inislead, if it creates the false impression that matters have not changed subsequently. ${ }^{89}$

Professor Donald Langevoort has correctly noted that there is no bright line between affirmative misrepresentations and halftruths, or between half-truths and nondisclosure..$^{0}$ Instead, all three arise in transactional settings in which the parties typically trade large amounts of information and, thus, represent a continuum, inaking coding at the margins sometimes difficult. ${ }^{91}$ Nonetheless, we predicted that courts are more likely to impose a duty to disclose when the informed party lied or told a half-truth in the same transaction in which she failed to disclose naterial information,

${ }^{86}$ Langevoort, supra note 29 , at $88-89$; see also Goldfarb, supra note 78 , at 24 ("While silence alone may not be actionable, if the vendor undertakes to speak, he must not conceal anything which would tend to qualify or contradict the facts which he had stated. In other words, to tell half of the truth is to make a half-false representation.").

${ }^{87}$ Restatement (Second) of Torts $\$ 529$ (1976). The Restatement elaborates, "[A] statement that contains only favorable matters and omits all reference to unfavorable matters is as much a false representation as if all the facts stated were untrue." Restatement (Second) of Torts $\S 529 \mathrm{cmt}$. a (1976).

${ }^{88}$ Restatement (Second) of Contracts $\$ 159 \mathrm{cmt}$. b (1979).

${ }^{89}$ Id.

${ }^{90}$ Langevoort, supra note 29 , at $95-96$.

${ }^{91}$ Id. at 96; cf. Goldfarb, supra note 78, at 25 (noting that "a business transaction is never entirely without conversation, and verbal exchanges nearly always involve, expressly or by implication, representations of fact"). 
than when the informed party's silence is unaccompanied by lies or half-truths.

\section{The Informed Party Actively Concealed Information}

It frequently has been asserted that if the informed party takes some affirmative steps to prevent detection of the truth by the uninformed party, then courts are more likely to require disclosure. As one commentator states, "[c]oncealment involves some positive action on the part of one to prevent the other from ascertaining some material fact, which without the interference he would probably have discovered., ${ }^{92}$

For example, the seller of land might cover a landfill, ditch, or other defect on the property with dirt and then fail to disclose this information to prospective purchasers. ${ }^{93}$ Similarly, if the uninformed party inquires about certain facts, the informed party might lead him (through words or actions) in a direction where the facts cannot be found. ${ }^{94}$ We predicted that courts are more likely to require disclosure in such instances than in a case where the seller had merely remained silent about some information, but had taken no steps to prevent discovery by the purchaser.

\section{F. Case Date}

One of the goals of this study was to identify any historical patterns in the data. Specifically, the aim was to test the frequently repeated but never empirically tested hypothesis that the doctrine of

\footnotetext{
${ }^{92}$ Wilson, supra note 30 , at 233 ; see also Goldfarb, supra note 78 , at 10 (distinguishing between "active concealment and mere nondisclosure").

${ }^{93}$ See Merchants Bank v. Campbell, 75 Va. 455, 460-61 (1881) (finding fraud where defendants stopped up the entrance to a valuable cavern and told plaintiffs that it was "nothing but a mud-hole"); Schneider v. Heath, (1813) 170 Eng. Rep. 1462, 1463 (K.B.) (finding fraud where defendants had removed a ship from the ways, where it had been sitting dry, and docked it in the water so that the plaintiffs could not observe defects on the bottom of the boat).

${ }^{94}$ See, e.g., Stewart v. Wyoming Cattle Ranche Co., 128 U.S. 383, 389 (1888) (finding fraud where defendant prevented plaintiff's agent from making inquiries which would have revealed material negative information); Chrisholm v. Gadsden, 1 S.C.L. (1 Strob.) 220, 224 (1847) (finding fraud where, in response to the uninformed party's inquiries, the informed party sent him to inspect an area of property where he knew the defect could not be discovered).
} 
caveat emptor had faded in importance over time and that, correspondingly, common-law disclosure duties had increased during the time period of our study (approximately 1789 to May 15, 2002) ${ }^{95}$ It has been asserted, in particular, that the law governing latent defects became more pro-disclosure in recent years. ${ }^{96}$

The most commonly asserted rationale for this perceived trend is an economic one: As America was transformed from an agrarian economy, in which people typically transacted primarily with persons whom they knew, to a commercial economy in which people regularly transacted with complete strangers, the law became more protective of the rights of uninformed parties in order to encourage commerce. ${ }^{97}$ In other words, legal changes occurred in response to economic changes.

We predicted, therefore, that the more recently a case was decided, the more likely a court would be to find that the informed party owed the uninformed party a duty to disclose. In addition, given Professor Kronman's claim regarding the trend over time for cases involving latent defects, we predicted that, for cases in which the withheld information related to a latent defect, courts would be more likely to find a duty to disclose during the period 1958 through 1983, as compared to the years before 1958 .

${ }^{95}$ See, e.g., Keeton, supra note 13, at 31 (" $[\mathrm{I}] \mathrm{t}$ is of course apparent that the content of the maxim 'caveat emptor,' used in its broader meaning of imposing risks on both parties to a transaction, has been greatly limited since its origin."); Kronman, supra note 1, at 24; Saul Levmore, Securities and Secrets: Insider Trading and the Law of Contracts, 68 Va. L. Rcv. 117, 133-34 (1982) ("Modern cases, however, can be read as signaling a trend toward increased disclosure requirements."). But see Dalley, Law of Deceit, supra note 2 , at 441 (finding that the law of deceit did not become more protective of the rights of uninformed parties from 1790-1860); Goldfarb, supra note 78, at 9 ("Writers who believe that [caveat emptor] has lost much of its content seem to be misreading the bulk of the decisions.").

${ }^{96}$ Kronman, supra note 1 , at 24 (arguing that, in "the last twenty-five years," disclosure duties regarding latent defects have increased dramatically).

${ }^{97}$ Horwitz, supra note 17, at 198-201 (arguing that, as markets and commerce became depersonalized, courts shifted their focus toward requiring disclosure of information not available to both parties, in contrast to both the strict caveat emptor and the fair price doctrines that had preceded it); see also Wahl, supra note 57, at 147 ("The doctrine of caveat emptor for sales replaced the sound-price rule (which presumed that any item sold at full price was sound) by the early 1800 s and remained strong through the early twentieth century."). 


\section{G. Court}

\section{Geographic Patterns}

We also wanted to determine whether any geographical patterns emerged in the cases. In particular, we wanted to test the assertion by some legal and economic historians that southern states were historically much less likely to impose disclosure duties on bargaining parties than were states in other regions. ${ }^{98}$

We predicted that courts in the South would be less likely to impose disclosure duties as compared to other regions during two early periods: $1793-1860$ and 1861-1940..$^{99}$ In addition, we examined regional trends in a recent period, 1941-2002.

\section{Differences Between Federal and State Courts}

Although we are not aware of any assertions made by commentators that differences exist among the cases according to jurisdiction, we wanted to test for such differences, both between state and federal courts, and among the federal circuit courts. Because commentators have not asserted that such differences exist, we predicted that neither the deciding court's circuit nor the deciding court's nature as state or federal would have a significant influence on the probability that a court would find a duty to disclose.

Table 1 summarizes the hypotheses discussed throughout this Part. In addition, the table presents a summary of the basic results obtained from our regression analyses, the details of which appear in Part III.

\footnotetext{
${ }^{98}$ See, e.g., Dalley, Law of Deceit, supra note 2, at 431-32 (studying cases decided between 1790 and 1860 and claiming that cases in the South resulted in more proseller decisions than other regions).

${ }^{9}$ These dates were chosen somewhat arbitrarily because those who made claims about the South did not specify what they meant by "historically." The dates we chose correspond roughly with the end of the Civil War, which marks the last period of Dalley's dataset, and the beginning of World War II. Both events were highly significant for the South.
} 
Table 1

Summary of Hypotheses and Regression Results Dependent Variable: Log odds of court finding a duty to disclose

\section{INDEPENDENT VARIABLE}

Type of Information:

Information was intrinsic

Undisclosed information concerned personal intentions or opinions

Undisclosed information related to a latent defect

Information concerned a defect likely to cause bodily injury

Information concerned a defect likely to cause property damage

Information would have updated or corrected previously disclosed information

Type of Transaction:

Parties to transaction in a confidential or fiduciary relationship

Transaction concerned acquisition of insurance

Transaction concerned release from liability

Parties had unequal access to information

Transaction concerned the transfer of real property

Transaction concerned the transfer of a slave

Type of Acquisition:

Information was casually acquired Information was acquired through illegal or tortious means

\section{PREDICTED SIGN} OF COEFFICIENT

REGRESSION

RESULTS

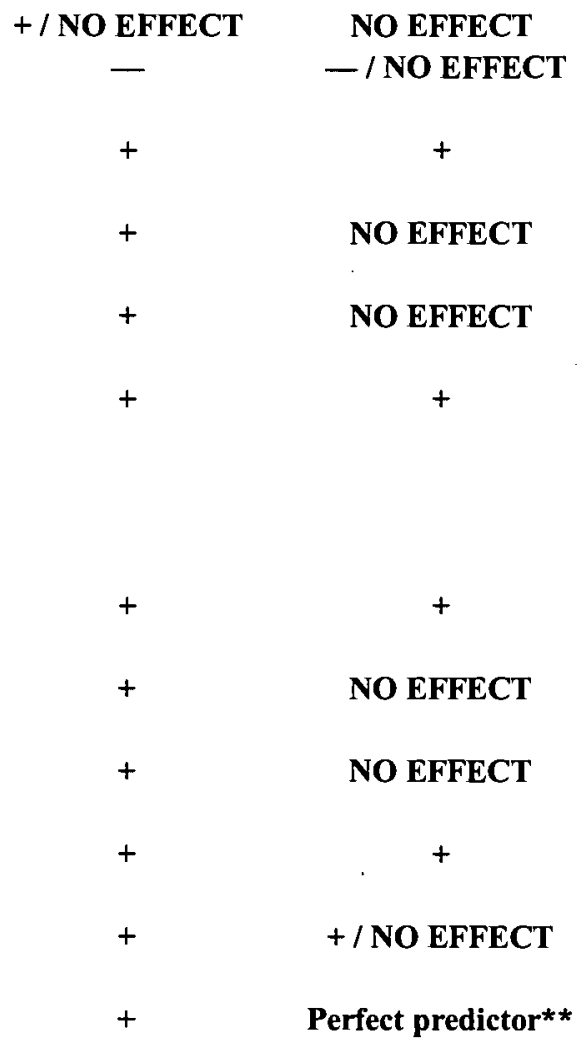

$+$

$+$ NO EFFECT 
Table 1 (continued):

\section{INDEPENDENT VARIABLE}

\section{Uninformed Party Characteristics:}

Uninformed party was the buyer or

lessee

Uninformed party was female

Uninformed party was sick, disabled, illiterate or elderly

\section{Informed Party Characteristics:}

Informed party made affirmative

misrepresentations

Informed party concealed information

Informed party told a half-truth

\section{Time Trends:}

Year case was decided

\section{Geographic Trends*:}

Decision made by state court

Decision made by federal circuit court
PREDICTED SIGN

OF COEFFICIENT

$+$

$+$

$+$

$+$

$+$

$+$

NO EFFECT

NO EFFECT

\section{REGRESSION \\ RESULTS}

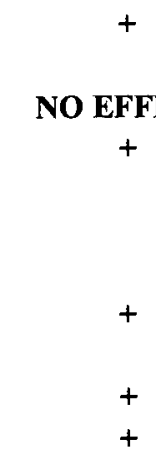

+ /NO EFFECT

3rd Cir: - / NO

EFFECT

6th Cir: -

7th Cir: -

* The predictions and results pertaining to the effects of the regional location of the court are provided in detail in Part 111.

** This variable is dropped from all regressions because, in each of the three cases involving slaves, the court found a duty to disclose.

TABLE 1: This table provides a summary of the hypotlieses derived from the literature regarding the factors inlluencing courts to find a duty to disclose and results from regressions used to test these hypotheses. Note that the table reports the results from all specifications. Indeterminate results indicate that the results are not robust to all specifications. 


\section{DATA COLLECTION}

\section{A. The Available Cases}

Like many other studies attempting to empirically examine case law or judicial developments, this study is limited to the Westlaw database, which does not include all decided cases. ${ }^{100}$ Instead, Westlaw excludes some unpublished cases, thus biasing the results to the extent that there is some systematic difference between available and unavailable cases. A description of West's process for choosing cases for inclusion in its database is contained in Appendix A.

In addition, this study accounts for neither the impact of settlement on the type of case that ultimately proceeds to the litigation stage nor the impact of judicial statements of case facts on our assumptions regarding what occurred in any given transaction. As argued by some coinmentators, judges may selectively repeat only the information that they consider relevant, or may allow their own biases to shape their interpretation and description of the facts of the case. ${ }^{101}$ As noted, however, this is typical of all legal analyses based on decided cases, including traditional doctrinal legal scholarship.

Given the inherent incompleteness of the Westlaw database, it is reasonable to infer that we introduced selection biases into our sample. While we acknowledge this, we do not think it limits the usefulness of our results given the focus on our study-to test commentators' claims regarding the factors that drive courts to impose a duty to disclose information-because these claims are based on the same set of cases from which we drew our sample.

${ }^{100}$ A study seeking to examine the case law of a particular jurisdiction for a short (and relatively modern) timeframe could examine all decided cases in some courts by obtaining unpublished opinions either through Westlaw or Lexis, the individual court's website, the court clerk, or some other collection service. This step is impractical in a study such as ours, which attempts to analyze a sample of the entire set of federal and state cases. Furthermore, as discussed in Appendix A, early American cases were often unreported, making any historical study of the common law incomplete.

${ }^{101}$ See, e.g., Robert P. Burns, The Lawfulness of the American Trial, 38 Am. Crim. L. Rev. 205, 219 (2001) ("[L]awyers ... often believe that the account of the facts provided by appellate courts is deeply unfair."); Anthony D'Amato, The Ultimate Injustice: When a Court Misstates the Facts, 11 Cardozo L. Rev. 1313, 1325-31 (1990) (describing Judge Easterbrook's misstatement of the facts in the case of Branion $v$. Gramly). 


\section{B. The Collection Process}

We ran our search on May 15, 2002, and retrieved cases in the "Allcases-old" and "Allcases" databases on Westlaw. The search retrieved 217 cases in the Allcases-old database, resulting in 152 observations. ${ }^{102}$ The search retrieved 1086 cases in the Allcases database, from which we drew a random sample resulting in 314 observations, for a total of 466 observations..$^{103}$ Courts found a duty to disclose in $51 \%$ of the cases in our sample. ${ }^{104}$

\section{The Search Terms}

The search terms we employed were: duty $/ 3$ disclos! /p fraud $/ \mathrm{p}$ (contract tort) \% securities $/ 3$ act. Because we focused solely on common-law (as opposed to statutory) duties to disclose, we purposely designed the search to exclude cases decided under the federal statutory securities laws; as a result, we also excluded cases that might have referenced these securities laws in reaching a decision. Consequently, our dataset included only one case involving fraudulent silence in connection with the purchase or sale of a security.

\section{Case Coding}

Case coding was done by research assistants, with the supervision of one of the authors. Detailed information regarding this process is contained in Appendix A.

Given our focus on common-law rules, cases decided under a statute were especially difficult to code. Many states have attempted to codify or expand the law governing fraudulent nondis-

\footnotetext{
${ }^{102}$ Some cases are not usable, either because the court failed to reach a decision on the merits with respect to the element of duty, because the search terms identified a case that does not actually address the question being studied, or because the court's decision did not reflect the common law because it was based on a statute or was impacted by a warranty or waiver. As a result, the number of observations is less than the number of cases retrieved. See Appendix A for further explanation on this.

${ }^{103}$ The complete dataset is available from the authors upon request.

${ }^{104}$ Although this statistic is consistent with the predictions of the Priest-Klein model, for reasons discussed infra notes 171-174 and accompanying text, we believe this statistic is anomalous and unrelated to the Priest-Klein model. See George L. Priest \& Benjamin Klein, The Selection of Disputes for Litigation, 13 J. Legal Stud. 1, 6 (1984).
} 
closure in particular areas, especially real estate sales ${ }^{105}$ consumer transactions of all types, ${ }^{106}$ car sales, and health care delivery. ${ }^{107}$ As a result, some cases in these areas (especially more recent cases) might be decided under a statute. We did not automatically exclude such cases from our dataset, however. Instead, when the statute (or, where relevant, the legislative history) simply prohibited "fraud" without defining it (thus forcing courts to return to the common law for a definition) or merely codified the common law, we coded the case as if it had been decided under the common law. Where the statute attempted to change or expand the common law, however, or where the statute specifically imposed liability for a failure to disclose (as is typical, for example, in some statutes governing real estate sales), we excluded the case. ${ }^{108}$

Finally, we directed the case coders to make an evaluation of the variables in each case that was independent of the court's evaluation of the variables. This method served three functions: first, and most importantly, it was a necessary step to using all of the cases, as only rarely did a court draw specific conclusions regarding every variable that we desired to code; second, it allowed us to adopt bright-line coding rules that reduced subjectivity and eliminated the need to master the law across numerous time frames and jurisdictions; third, it allowed us to minimize the impact of conscious or unconscious judicial mischaracterizations of fact. We discuss each of these functions, in turn.

\footnotetext{
${ }^{105}$ See, e.g., Cal. Civ. Code $\$ 1102$ (West 2005) (delineating the seller's disclosure obligations when transferring real property).

${ }^{106}$ Elizabeth A. Dalberth, Unfair and Deceptive Acts and Practices in Real Estate Transactions: The Duty to Disclose Off-Site Environmental Hazards, 97 Dick. L. Rev. 153,157 (1992) (noting that, beginning in the mid-1960s and 1970s, states began to enact unfair and deceptive act and practices statutes to protect consumers in most transactions).

${ }^{107}$ Grant H. Morris, Dissing Disclosure: Just What the Doctor Ordered, 44 Ariz. L. Rev. 313, 334 n.115 (2002) (discussing informed consent statutes); Ryan Steven Johnson, Note, ERISA Doctor in the House? The Duty to Disclose Physician Incentives to Limit Health Care, 82 Minn. L. Rev. 1631 (1998) (discussing disclosure duties imposed on various parties by ERISA).

${ }^{108}$ A surprisingly large number of such cases, especially cases concerning real estate sales, remain in our dataset. This is because many state statutes imposing liability for a failure to disclose also permit an informed waiver of the statute's protection. In many of the real estate cases in our dataset, such a waiver was procured, leaving the parties to rely on common-law remedies.
} 
First, if the court's recitation of facts in a particular case did not permit the coding of every variable, we excluded the case from the dataset. ${ }^{109}$ However, when the recitation of facts contained sufficient information to code each variable, we retained the case and coded for each variable, even if the court did not draw specific conclusions regarding each variable. To illustrate, we found that courts rarely specifically concluded whether the parties had equal access to information. However, the court's recitation of facts generally allowed the case coder to make such a conclusion. This allowed us to test whether, as hypothesized by Professor Scheppele, equal access to information significantly influenced case outcomes, even when the court purported to base its decision on other grounds and, in fact, may not have discussed the parties' relative access to information at all. ${ }^{110}$

Second, because our study spans numerous time frames and jurisdictions, it was simply impractical to master the specifics of the law with respect to each variable. This was especially true with respect to the fiduciary duty variable. Instead, we adopted bright-line rules that reflected the general weight of authority across jurisdictions and did not apply the fiduciary duty rules specific to the jurisdiction deciding the case. ${ }^{11}$

Third, on rare occasions, the case coder may simply have disagreed with the court's characterization of a particular variable. In such cases, we directed the case coder to code the variable consistent with our definitions of each variable, rather than the court's conclusions. For example, even if a court concluded that a particular doctor-patient relationship was not confidential, our case coders would have coded such a relationship as fiduciary or confidential, because we adopted in advance a bright-line rule that all such relationships would be treated as confidential. Similarly, we directed our case coders to apply the bright-line definition we developed (based on Professor Kronman's theories) for determining whether information was casually acquired, regardless of whether the court

\footnotetext{
${ }^{109}$ See Appendix, Section 2 (discussing the reasons that particular cases were excluded from the dataset).

${ }^{110}$ See Scheppele, supra note 2, at 133 (arguing that the common-law rule holding sellers to greater disclosure obligations than buyers is actually a rule of equal access because buyers are unlikely to have access to information unavailable to the seller).

${ }^{11}$ See supra Section I.B.1 (discussing the fiduciary duty variable).
} 
determined the information in question was casually acquired. ${ }^{112}$ This approach minimizes both subjectivity in coding and any judicial tendency to characterize variables in a manner that supports the court's ultimate ruling. ${ }^{13}$

\section{Summary Statistics}

Table 2 provides a short description of the variables related to case characteristics and summary statistics for the entire sample, for the sub-sample of cases requiring disclosure, and for the subsample of cases not requiring disclosure. Table 3 provides the same information for variables related to decision date, geographic region, and jurisdiction.

\section{RESULTS}

The claims presented in Part I predict that the probability that a court will find a duty to disclose depends, in part, on five groups of factors: the type of information withheld by the informed party, the type of transaction in which the parties engaged, the way in which the information was acquired by the informed party, the characteristics of the uninformed party, and the behavior of the informed party. In addition to these factors, we also investigate trends related to the decision date, geographic location of the court, and jurisdiction.

Our dependent variable-DISCLOSURE - is dichotomous; therefore, linear regression models such as Ordinary Least Squares

${ }^{112}$ See supra Section I.C.1 (discussing the definition of casually acquired information). It should be noted that, most often, the court either made no conclusion with respect to this variable or made a conclusion consistent with our own. However, on rare occasions when the court's conclusion was inconsistent with our bright-line definition, the case coder was directed to ignore the court's conclusion and apply our definition.

${ }^{113}$ Like all readers of judicial opinions, we are still limited by the court's statement of facts. Our objective approach frees us only from the court's erroneous conclusions regarding the facts, not from the statement of facts itself. See D'Amato, supra note 101 (arguing that courts sometimes purposely misstate facts). In other words, if a court incorrectly reports that two bargaining parties were married, the case coders would treat the relationship as confidential, even if the court's reporting of this fact was incorrect. In contrast, if the court correctly reported that the bargaining parties were married but then concluded that the relationship was not confidential, our case coders would disagree and treat the relationship as confidential. 
are not appropriate to perform estimations. ${ }^{114}$ Instead, we employ logistic regressions to estimate the effects of our independent variables on the predicted $\log$ odds that a court will require disclosure. ${ }^{115}$ Using regression analysis to measure the effects of the independent variables on the predicted log odds that a court will require disclosure allows us to draw inferences about which factors significantly influence court decisions when other factors are taken into account.

${ }^{114}$ A dichotomous variable is one that can take on only one of two possible values. The variable DISCLOSURE is coded either as a " 0 " or a " 1 " for each observation in our sample.

${ }^{115}$ The dependent variable is the predicted log odds that the event will occur, rather than the probability that the event will occur, because the log odds form satisfies the assumptions required to obtain valid regression results. The coefficients generated when using this form as the dependent variable lack an intuitively meaningful scale of interpretation, however. Thus, when interpreting the results in the text that follows, we interpret a coefficient that is statistically significant and positive as indicating that the presence of the associated independent variable leads to an increase in the likelihood that the court will require disclosure. See Gregory C. Sisk, Michael Heise \& Andrew P. Morriss, Charting the Influences on the Judicial Mind: An Empirical Study of Judicial Reasoning, 73 N.Y.U. L. Rev. 1377, 1431-32 n.230 (1998) (explaining the technical differences between Ordinary Least Squares and logit models). For an introduction to logistic regression methodology, see generally Fred C. Pampel, Logistic Regression: A Primer (Sage Univ. Papers, Quantitative Applications in the Soe. Sciences Series No. 7-132, 2000). 


\section{Table 2}

\section{Variable Descriptions and Summary Statistics}

Case Characteristics

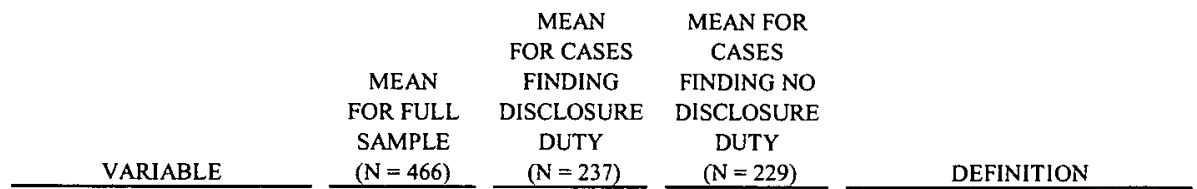

Dependent Variable:

DISCL

$0.51 \quad(238)$

Independent Variables:

Type of Information: INSTRINSIC

PERSONAL

LATENT

INJURE

DAMAGE

UP_CORR

Type of Transaction:

CONFID

0.2

$0.97 \quad(452)$

0.09

0.13

0.03

(I2)

0.08

(36)

0. I 3

(62)

(452)

0.97

(230)

0.97

(42) 0.05

(I2)

0.13

(60) 0.20

(48) 0.05

(8) 0.02

(23) 0.06

(4I) 0.09

INSURE

RELEASE

ACCESS

PROPERTY

SLAVE

Type of Acquisition:

CASUAL

$0.80 \quad(371) \quad 0.80 \quad(190)$

0.79

ILLEGAL
I = court imposed liability for fraudulent silence
(222)

(30)

(I2)

(I2)

(4)

(I3)

(2I) to cause property damage $1=$ information would have updated or corrected previously disclosed information

I = information related to subject matter of transaction

$1=$ information concerned personal intentions or opinions 1 = information related to a latent defect

1 = information concerned a defect likely to cause bodily injury

$1=$ information concerned a defect

(29) 1 = parties to transaction in a confidential or fiduciary relationship

(I2) $1=$ transaction concerned acquisition of insurance

(6) I = transaction concerned release from liability

(103) $I$ = parties had unequal access to information

(6I) $1=$ transaction concerned the transfer of real property

(0) $1=$ transaction concerned the transfer of a slave

(18I) 1 = information was casually acquired

(1) 1 = information was acquired through illegal or tortious means 


\section{Table 2 (continued)}

\begin{tabular}{|c|c|c|c|c|c|c|c|}
\hline VARIABLE & $\begin{array}{c}\text { ME } \\
\text { FOR } \\
\text { SAN } \\
(\mathrm{N}=\end{array}$ & $\begin{array}{l}\text { AN } \\
\text { FULL } \\
\text { IPLE } \\
466) \\
\end{array}$ & $\begin{array}{r}\mathrm{M} \\
\text { FOR } \\
\text { FIN } \\
\text { DISCl } \\
\mathrm{D} \\
(\mathrm{N} \\
\end{array}$ & $\begin{array}{l}\text { AN } \\
\text { ASES } \\
\text { ING } \\
\text { OSURE } \\
\text { TY } \\
\text { 237) } \\
\end{array}$ & $\begin{array}{r}\mathrm{ME} f \\
\mathrm{C} \\
\mathrm{FIND} \\
\mathrm{DISC} \\
\mathrm{D} \\
\mathrm{N}\end{array}$ & $\begin{array}{l}\text { FOR } \\
\text { ES } \\
\text { G NO } \\
\text { SURE } \\
\text { rY } \\
229) \\
\end{array}$ & DEFINITION \\
\hline BUYER & 0.40 & (186) & 0.46 & (I09) & 0.34 & (77) & $\begin{array}{l}1=\text { uninformed party was the } \\
\text { buyer or lessee }\end{array}$ \\
\hline FEMALE & 0.12 & (55) & 0.14 & (33) & 0.10 & (22) & $1=$ uninformed party was female \\
\hline SICK & 0.06 & (27) & 0.08 & (19) & 0.03 & (8) & $\begin{array}{l}1=\text { uninformed party was sick, } \\
\text { disabled, illiterate or elderly }\end{array}$ \\
\hline \multicolumn{8}{|c|}{ Informed Party Characteristics: } \\
\hline LIED & 0.20 & (91) & 0.35 & (83) & 0.03 & (8) & $\begin{array}{l}\mathrm{I}=\text { informed party made } \\
\text { affirmative misrepresentations }\end{array}$ \\
\hline CONCEAL & 0.08 & (36) & 0.14 & (33) & 0.01 & (3) & $\begin{array}{l}I=\text { informed party concealed } \\
\text { information }\end{array}$ \\
\hline HALF_TRUTH & 0.23 & (106) & 0.37 & (87) & 0.08 & (19) & $1=$ informed party told a half-truth \\
\hline
\end{tabular}

TABLE 2: This table provides a summary of the variables representing case characteristics employed in the einpirical analysis along with the mean and description of each variable. The entire sample consists of 466 cases. The mean for each variable for the full sample can be interpreted as the percentage of cases characterized by the variable. For example, a mean of $51 \%$ for D1SCLOSURE indicates that $51 \%$ of the cases held the informed party liable. The numbers in the parentheses indicate the number of cases (that is, mean times total number of cases in the sample). 


\section{Table 3}

Variable Descriptions and Summary Statistics Case Date, Geographic Region, and Jurisdiction

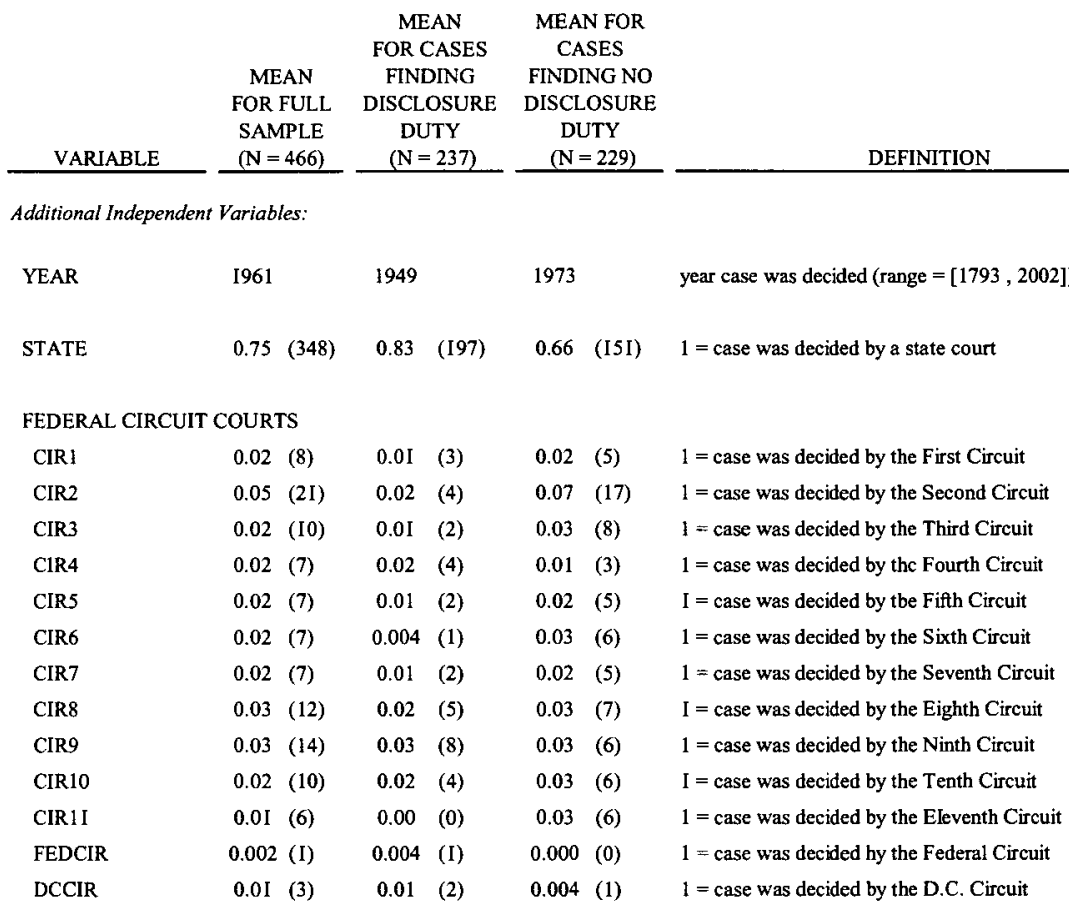

GEOGRAPHIC REGIONS

$\begin{array}{llllllll}\text { WEST } & 0.14 & (66) & 0.16 & (38) & 0.12 & (28) & 1 \text { = case was decided by a court in the West } \\ \text { SOUTH } & 0.25 & (\mathrm{I17}) & 0.23 & (55) & 0.27 & (61) & 1 \text { = case was decided by a court in the South } \\ \text { MIDATLANTIC } & 0.23 & (106) & 0.24 & (58) & 0.21 & (48) & 1 \text { = case was decided by a court in a Mid-Atlantic state } \\ \text { SOUTHWEST } & 0.08 & (36) & 0.08 & (18) & 0.08 & (18) & 1 \text { = case was decided hy a court in the Southwest } \\ \text { NEWENGLAND } & 0.07 & (32) & 0.06 & (15) & 0.07 & (17) & 1 \text { = case was decided by a court in New England } \\ \text { MIDWEST } & 0.24 & (110) & 0.22 & (53) & 0.25 & (57) & 1 \text { = case was decided by a court in the Midwest }\end{array}$

TABLE 3: This table provides a summary of the variables representing case date, geographic region and jurisdiction employed in the empirical analysis along with the mean and description of each variable. The entire sample consists of 466 cases. The numbers in the parentheses indicate the number of cases (that is, mean times total number of cases in the sample).

Throughout this Part, it is important to note that all reported results are aggregate results and therefore do not reflect differences across jurisdictions. In other words, a reported result that a particular variable (for example, PROPERTY) is insignificant could mean 
that the variable is truly an insignificant predictor of case outcomes in all jurisdictions. At the same time, however, it is possible that the variable's effect on decisions is significant and positive in the First Circuit, canceling out the fact that it is significant and negative in the Second Circuit. Similarly, a reported result that a particular variable (for example, ACCESS) is positive and significant could mean that the variable is a significant predictor of case outcomes in all jurisdictions or only a few. Indeed, it is possible that the variable's effect is negative and slightly significant in only one or a few jurisdictions, but is counteracted by the variable's highly significant positive impact in other jurisdictions. In other words, this project is designed to study overall general trends in decisions that correspond to claims made by legal scholars and economic historians regarding general trends and patterns in the law governing fraudulent nondisclosure. We do not attempt to describe the law for any particular jurisdiction.

Table 4 presents basic results for several logistic regression analyses that test the influence of various sets of independent variables on the likelihood that a court will find that the informed party owed a duty of disclosure to the uninformed party. ${ }^{116}$ Various specifications were analyzed to test the robustness of the results given the large number of independent variables included in the model. ${ }^{117}$ The following Sections provide a variable-by-variable analysis of the results derived from the regression analysis and various statistical tests.

\footnotetext{
${ }^{116}$ We also analyzed the data using probit analysis and obtained results that were nearly identical to the results we obtained using logistic regression analysis. For an explanation of how probit analysis differs from logistic regression analysis, see Pampel, supra note 115 , at 54-68.

${ }^{117}$ By "specification" we mean the construction of the empirical equation that we estimate to generate results regarding how the independent variables affect the dependent variable. The process of specifying the model includes determining: (1) which variables should be included in the model, (2) the functional form of the model, and (3) the probabilistic assumptions made about thc dependent variable, the independent variables, and the error term. A result is "robust" if it does not vary significantly with the specification of the model.
} 
Table 4

Maximum-Likelihood Logit Estimation Results Dependent Variable: Predicted log odds of court finding duty to disclose

\begin{tabular}{|c|c|c|c|c|c|c|}
\hline \multirow{2}{*}{$\frac{\text { VARIABLE }}{\text { Type of Information: }}$} & \multicolumn{6}{|c|}{$\begin{array}{c}\text { COEFFICIENT } \\
\text { (P VALUE) }\end{array}$} \\
\hline & & & & & & \\
\hline INTRINSIC & $\begin{array}{l}0.32 \\
(0.57)\end{array}$ & & & & & $\begin{array}{l}0.16 \\
(0.86)\end{array}$ \\
\hline PERSONAL & $\begin{array}{c}-0.93^{* *} \\
(0.01)\end{array}$ & & & & & $\begin{array}{l}-0.32 \\
(0.56)\end{array}$ \\
\hline LATENT & $\begin{array}{c}1.77^{* * *} \\
(0.00)\end{array}$ & & & & & $\begin{array}{c}2.24 * * * \\
(0.00)\end{array}$ \\
\hline INJURE & $\begin{array}{c}0.07 \\
(0.92)\end{array}$ & & & & & $\begin{array}{c}1.05 \\
(0.20)\end{array}$ \\
\hline DAMAGE & $\begin{array}{l}-0.63 \\
(0.18)\end{array}$ & & & & & $\begin{array}{l}-0.23 \\
(0.72)\end{array}$ \\
\hline UP_CORR & $\begin{array}{c}0.90^{* * *} \\
(0.00)\end{array}$ & & & & & $\begin{array}{l}\mathrm{I} .06^{* *} \\
(0.01)\end{array}$ \\
\hline \multicolumn{7}{|l|}{ Type of Transaction: } \\
\hline CONFID & & $\begin{array}{l}{\left[.82^{* * *}\right.} \\
(0.00)\end{array}$ & & & & $\begin{array}{c}2.65^{* * *} \\
(0.00)\end{array}$ \\
\hline INSURE & & $\begin{array}{l}0.14 \\
(0.77)\end{array}$ & & & & $\begin{array}{l}-0.13 \\
(0.84)\end{array}$ \\
\hline RELEASE & & $\begin{array}{c}0.53 \\
(0.39)\end{array}$ & & & & $\begin{array}{c}0.5 \mathrm{I} \\
(0.55)\end{array}$ \\
\hline ACCESS & & $\begin{array}{l}I .19^{* * *} \\
(0.00)\end{array}$ & & & & $\begin{array}{c}1.03^{* * *} \\
(0.00)\end{array}$ \\
\hline PROPERTY & & $\begin{array}{l}1.27 * * * \\
(0.00)\end{array}$ & & & & $\begin{array}{c}0.29 \\
(0.45)\end{array}$ \\
\hline \multicolumn{7}{|l|}{ Type of Acquisition: } \\
\hline CASUAL & & & $\begin{array}{c}0.09 \\
(0.71)\end{array}$ & & & $\begin{array}{l}0.76^{*} \\
(0.06)\end{array}$ \\
\hline ILLEGAL & & & $\begin{array}{c}1.10 \\
(0.34)\end{array}$ & & & $\begin{array}{c}1.26 \\
(0.46)\end{array}$ \\
\hline \multicolumn{7}{|l|}{ Uninformed Party Characteristics: } \\
\hline BUYER & & & & $\begin{array}{l}0.54^{* *} \\
(0.0 \mathrm{I})\end{array}$ & & $\begin{array}{l}1.18^{* * *} \\
(0.00)\end{array}$ \\
\hline FEMALE & & & & $\begin{array}{c}0.28 \\
(0.36)\end{array}$ & & $\begin{array}{c}0.04 \\
(0.93)\end{array}$ \\
\hline SICK & & & & $\begin{array}{l}0.85^{*} \\
(0.06)\end{array}$ & & $\begin{array}{l}1.58^{* *} \\
(0.03)\end{array}$ \\
\hline \multicolumn{7}{|l|}{ Informed Party Characteristics: } \\
\hline LIED & & & & & $\begin{array}{c}2.93^{* * *} \\
(0.00)\end{array}$ & $\begin{array}{c}3.17^{* * *} \\
(0.00)\end{array}$ \\
\hline CONCEAL & & & & & $\begin{array}{c}2.82^{* * *} \\
(0.00)\end{array}$ & $\begin{array}{c}3.15 * * * \\
(0.00)\end{array}$ \\
\hline HALF_TRUTH & & & & & $\begin{array}{c}2.18^{* * *} \\
(0.00)\end{array}$ & $\begin{array}{c}2.81 * * * \\
(0.00)\end{array}$ \\
\hline Constant & $\begin{array}{l}-0.47 \\
(0.40)\end{array}$ & $\begin{array}{c}-1.60^{* * *} \\
(0.00)\end{array}$ & $\begin{array}{l}-0.04 \\
(0.84)\end{array}$ & $\begin{array}{l}-0.26 * * \\
(0.04)\end{array}$ & $\begin{array}{r}-1.01^{* * *} \\
(0.00)\end{array}$ & $\begin{array}{r}-4.4 I^{* * *} \\
(0.00)\end{array}$ \\
\hline $\operatorname{LR} x^{2}$ & $\begin{array}{l}42.22 \\
(0.00)\end{array}$ & $\begin{array}{r}109.37 \\
(0.00)\end{array}$ & $\begin{array}{l}\text { I.12 } \\
(0.57)\end{array}$ & $\begin{array}{l}13.50 \\
(0.00)\end{array}$ & $\begin{array}{r}178.01 \\
(0.00)\end{array}$ & $\begin{array}{r}310.58 \\
(0.00)\end{array}$ \\
\hline Pseudo $R^{2}$ & 0.07 & 0.17 & 0.00 & 0.02 & 0.28 & 0.48 \\
\hline $\mathbf{N}$ & 466 & 463 & 466 & 466 & 466 & 463 \\
\hline
\end{tabular}

$* p<0.10$

$* * p<0.05$

$* * * p<0.01$ 
TABLE 4: This table provides the maximum-likelihood logit estimation results for the effects of case characteristics on whether the court found a duty to disclose. These results do not include the effects of the decision date or the geographic location and jurisdiction of the court. See Table 6 for results taking these characteristics into account.

Note: LR $\square^{2}$ indicates the result from testing the null hypothesis that alJ coefficients in the model, except the constant, equal zero. In addition, it should be noted that, although pseudo $\mathrm{R}^{2}$ statistics provide a quick way to compare the fit of different models for the same dependent variable, they lack the straightforward explained-variance interpretation of true $R^{2}$ in OLS regressions.

\section{A. The Type of Information}

Recall that commentators have suggested that particular characteristics of the withheld information influence courts' decisions in fraudulent silence cases. These characteristics include whether the information was intrinsic or extrinsic in nature, related to personal intentions or opinions versus facts, related to latent or patent defects, concerned a defect likely to cause bodily injury or property damage, and would have updated or corrected previously disclosed information. ${ }^{118}$

\section{Whether the information was intrinsic, as opposed to extrinsic or} market, information does not explain the variation in outcomes because $97 \%$ of the cases in the sample involve intrinsic information

\section{a. General Results}

We hypothesized that cases involving intrinsic information are more likely to result in a finding that the informed party owed a disclosure duty to the uninformed party in early years, but that the importance of the intrinsic/extrinsic distinction disappears over time. ${ }^{19}$

As the results displayed in Table 4 indicate, the coefficient on INTRINSIC is not statistically different from zero $(p>0.10)$, indicating that the intrinsic nature of the information is not a factor that helps to explain the variation in case outcomes. ${ }^{120}$ It should be

\footnotetext{
${ }^{118}$ See supra Section I.A.

${ }^{119}$ See supra Section I.A.1 (discussing assertions by courts and commentators regarding extrinsic information).

${ }^{120}$ To test the statistical significance of any result, a test statistic is calculated (the details of which are unimportant for purposes of this exposition). The $p$-value is interpreted as the probability of observing a test statistic as extreme or more extreme than the computed test statistic assuming the null hypothesis is true (for example, the
} 
noted, however, that this result is driven by the fact that $97 \%$ of the cases in the full sample involve intrinsic, rather than extrinsic, information.

Nonetheless, other statistical tests allow us to cast some doubt on the conventional wisdom regarding the relative likelihood that courts will require the disclosure of intrinsic information. Specifically, tests for the equality of proportions cast doubt on claims that courts are more likely to require the disclosure of intrinsic information than extrinsic information. Of the 14 cases in our dataset involving extrinsic information, the court found the existence of a duty to disclose in 6 of the cases (or $43 \%$ ). On the other hand, $51 \%$ of the cases (or 231 of 452) involving intrinsic information resulted in a finding that the informed party owed the uninformed party a duty to disclose. Our analysis thus reveals that courts are not statistically more likely to require the disclosure of intrinsic information as opposed to extrinsic information $(p=0.28)$.

Moreover, an interesting question here is why so few cases involving extrinsic information result in judicial decisions. Apparently, cases involving extrinsic information are either more likely to settle, or less likely to be brought by plaintiffs. One possible explanation is that plaintiffs are simply less likely to bring claims for fraudulent silence when the withheld information is extrinsic, rather than intrinsic. This conjecture is supported by two potential explanations. First, it is possible that individuals are less likely to possess extrinsic information unknown to their bargaining partners as compared to intrinsic information. Second, the uninformed party is unlikely to discover that the informed party knew of extrinsic information. For example, it is unlikely that a home buyer would discover that the seller had access to nonpublic information regarding the fact that a highway was going to be built across an adjacent lot. By contrast, the uninformed party may be able to eas-

coefficient on INTRINSIC equals zero). "Extreme" means in the direction of the alternative hypothesis (for example, the coefficient on INTRINSIC is different from zero). In this case, assuming the null hypothesis is true, the chance of observing a test statistic as or more extreme than the computed test statistic is greater than $10 \%$. This means that, at a confidence level of $10 \%$, we cannot reject the null hypothesis that the coefficient is equal to zero. Customarily, in social science research, a null hypothesis is rejected in favor of an alternative hypothesis if the $p$-value is less than $5 \%$ (in some cases, a $10 \%$ cutoff is used). In all cases, we report the exact $p$-values derived from the statistical tests, leaving readers to evaluate the strength of the evidence. 
ily surmise that someone selling a car that she has owned for many years was aware that the engine fails to start in cold weather.

\section{b. Interaction Effects}

Recall from Part I that some commentators assert that some other factor, rather than the intrinsic nature of the information, actually explains the variation in fraudulent silence cases. For example, Professor W. Page Keeton argues that, although courts require the disclosure of intrinsic information more frequently than extrinsic information, it is really the lack of equal access to intrinsic information relative to extrinsic information that is driving case outcomes. ${ }^{121}$ Similarly, Keeton argues that the intrinsic/extrinsic distinction fails to explain case outcomes when the uninformed party is the purchaser, as opposed to the seller. ${ }^{122}$ Finally, Professor Anthony Kronman asserts that it is really the fact that extrinsic information is typically deliberately acquired that drives case outcomes, rather than the mere fact that the information is extrinsic. ${ }^{123}$

To test these claims, we ran three separate regressions to determine if interaction effects are present between INTRINSIC and the three variables ACCESS, CASUAL, and BUYER. ${ }^{124}$ The results suggest that there are no significant interaction effects between INTRINSIC and these three variables. This result, however, is most likely due to the lack of variation in the INTRINSIC variable and the resulting collinearity ${ }^{125}$ between the interaction term and the variables ACCESS, CASUAL, and BUYER.

${ }^{121}$ See supra note 13 and accompanying text.

${ }^{122}$ See supra note 15 and accompanying text.

${ }^{123}$ See supra note 14 and accompanying text.

${ }^{124}$ By including interaction effects in the analysis, we are able to measure the amount of change in the slope of the regression of the dependent variable, say $Y$, on an imdependent variable, say $X$, when a second independent variable, say $Z$, changes by one unit. A positive and significant coefficient on an interaction term, $X{ }^{*} Z$, implies that the higher the $X$, the greater the effect of $Z$ on $Y$. Similarly, the higher the $Z$, the greater the effect of $X$ on $Y$.

${ }^{125}$ Two variables are collinear if they are highly correlated. When two independent variables are highly correlated, they both introduce essentially the same information into the regression. This violates one of the necessary assumptions of the logit model. In addition, collinearity in this case implies that the interaction term has very little variation and, therefore, is not likely to be a significant factor in explaining the variation in outcomes. 


\section{c. Time Trends}

Recall that some commentators claim that courts, over time, put less weight on whether the information is intrinsic or extrinsic, and instead focus on other factors. ${ }^{126}$ To test claims about the influence of intrinsic information over time, we tabulated the number of cases that involved intrinsic information and in which the court found a duty to disclose during three periods: 1793-1899, 19001949 , and 1950-2002. ${ }^{127}$ Table 5 presents the results from this tabulation.

\section{Table 5}

Tabulations for Cases Involving Intrinsic Information

\begin{tabular}{ccc} 
PERIOD & $\begin{array}{c}\text { COURT FOUND } \\
\text { DUTY TO } \\
\text { DISCLOSE }\end{array}$ & $\begin{array}{c}\text { COURT FOUND NO } \\
\text { DUTY TO } \\
\text { DISCLOSE }\end{array}$ \\
\cline { 3 - 3 } $1793-1899$ & $33(77 \%)$ & $10(23 \%)$ \\
$1900-1949$ & $72(70 \%)$ & $31(30 \%)$ \\
$1950-2002$ & $126(41 \%)$ & $180(59 \%)$
\end{tabular}

TABLE 5: This table presents the results of tabulations of the number of cases involving intrinsic information by outcome for three periods: 1793-1899, 1900-1949, and 1950-2002.

Tests for the equality of proportions were performed to investigate the claim that, over time, courts place less emphasis on whether the information was intrinsic or extrinsic. ${ }^{128}$ First, we tested whether courts impose disclosure duties in a statistically signifi-

\footnotetext{
${ }^{126}$ See supra note 16 and accompanying text.

${ }^{127}$ These periods were chosen arbitrarily. The results do not vary, however, if different periods are used to test the hypothesis.

${ }^{128}$ In particular, we ran two-sample, one-sided tests on the equality of proportions (calculated using the data from two distinct samples). These tests pit the null hypothesis of equal proportions against an alternative hypothesis that one proportion is statistically significantly greater than the other, controlling for sample size. If the null hypothesis is accepted over the alternative hypothesis, then one may conclude that the difference in proportions is due to chance.
} 
cantly lower proportion of cases involving intrinsic information during the period 1793-1899 than in the period 1900-1949. The result indicates that no statistically significant difference exists between the percentages $(p=0.20)$. However, the proportion of cases involving intrinsic information in which the court found a duty to disclose during the period 1900-1949 was statistically significantly higher than the proportion of such cases during the period 1950$2002(p=0.00)$. Therefore, the data do show some support for the claim that factors other than whether the information was intrinsic or extrinsic became more important to courts over time. This alone, however, does not allow us to determine whether this trend is due to the relatively greater emphasis courts place on the nature of the information as intrinsic versus extrinsic, or the general decrease over time in the likelihood that courts will find a duty to disclose. $^{129}$

2. Whether the information involves personal intentions or opinions, as opposed to facts, does not explain the variation in case outcomes because the number of cases involving such information is too small to obtain useful results from regression analysis. Outcome counts, however, cast doubt on the conventional wisdom relating to personal intentions.

Recall that there is almost universal agreement among commentators that the disclosure of personal intentions or opinions is not required by the common law. ${ }^{130}$ The results presented in Table 4 indicate that the coefficient on PERSONAL is significant and negative $(p=0.01)$ when we control only for variables relating to the type of information. When we control for all case characteris-

\footnotetext{
${ }^{129}$ In theory, it is possible to control for the general trend over time and other influences on court decisions, by estimating the influence of intrinsic information over time using a logistic regression that includes the twenty variables representing case characteristics and YEAR, together with a term to capture the interaction of year and intrinsic mformation (INTRINSIC * YEAR). The coefficient on the interaction term would allow us to determine whether courts were more or less likely to require disclosure in cases involving intrinsic information in later years relative to earlier years. The coefficient on the interaction term was not statistically significantly different from zero $(p=0.67)$. Due to the lack of variation in the INTRINSIC variable, however, this regression result does not provide us with any useful information. See supra note 120 and accompanying text (discussing problems arising from the fact that $97 \%$ of the cases involve intrinsic information).

${ }^{130}$ See supra Section I.A.2.
} 
tics, however, the coefficient loses significance..$^{131}$ When all variables are included in the model, the coefficient on PERSONAL is insignificant $(p>0.10)$, indicating that whether the information is a personal opinion or intention versus a fact is not a factor that helps to explain the variation in case outcomes. This result most likely is driven by the fact that only $9 \%$ of the cases in the full sample involve personal intentions or opinions. The number of these sorts of cases might be too small to accurately identify the effect of this variable on the likelihood of mandated disclosure.

Nonetheless, simple outcome counts cast doubt on the conventional wisdom relating to the disclosure of personal intentions or opinions. Recall that consensus on the theory that the common law does not require the disclosure of personal intentions or opinions is so widespread that we hypothesized, first, that very few such cases are actually brought and, second, that when such cases do result in a decision the court nearly always permits such information to be withheld. While we note that simple counts do not control for the effects of other variables of interest and therefore results obtained from simple counts must be viewed with this limitation in mind, the results of the outcome count do not support either prediction regarding personal intentions or opinions. Of the 466 cases in the sample, 41 (or $9 \%$ ) involve information that was personal in nature. ${ }^{132}$ In a substantial portion of these cases (12 of the 41), the court ruled that the informed party had a duty to disclose the withheld opinion or intention. Given the strong agreement among

${ }^{131}$ Adding controls allows us to determine whether an observed correlation between a particular factor, such as whether the information involves personal intentions or opinions, and the probability that the court imposes a duty to disclose might be attributable to some other factor that possibly is correlated with the variable PERSONAL. For example, if a particular factor, such as whether the information is intrinsic, increases the probability that the court will find a duty to disclose and this factor is highly (but not perfectly) correlated with whether the information involves personal intentions or opinions, then including the variable INTRINSIC in the regression allows it to untangle the influences of INTRINSIC AND PERSONAL on the likelihood that the court will impose a disclosure duty.

${ }^{132}$ We can rule out the possibility that the lack of cases is attributable to courts' reluctance to impose liability for failure to disclose personal intentions or opinions in early cases, causing plaintiffs to eventually abandon such claims. Cases involving personal intentions or opinions appeared in the dataset uniformly over time. The first case of this sort was decided in 1852, five others were decided prior to 1950 , and the remaining cases were decided after 1950. 
commentators that the disclosure of opinions and personal intentions is not required, these results are surprising. We conclude that even the limited number of cases in our dataset involving information of this type challenges the conventional wisdom regarding the disclosure of opinions and intentions.

3. Courts are significantly more likely to require disclosure when the withheld information relates to a latent defect.

We hypothesized that courts would be more likely to require disclosure when the informed party withholds information relating to a latent defect. ${ }^{133}$ The results presented in Table 4 support this claim. The coefficient on LATENT is positive and highly significant $(p=0.00)$, even when we control for all variables relating to case characteristics. The commentators appear to have correctly argued that this factor significantly influences judicial decisions in fraudulent silence cases.

\section{Whether the undisclosed information would likely cause bodily} injury or property damage does not explain the variation in the case outcomes, most likely because the number of cases involving such information is too small to obtain useful results from regression analysis. Outcome counts, however, suggest that our hypotheses regarding information of this sort are not supported strongly by the data.

We hypothesized that the withholding of information likely to cause physical injury or property damage increases the likelihood of court-mandated disclosure. ${ }^{134}$ We coded cases separately for information concerning a defect likely to cause bodily injury (INJURE) and information concerning a defect likely to cause property damage (DAMAGE). The results presented in Table 4 indicate that the coefficients on INJURE and DAMAGE are insignificant ( $p>0.10$ in all cases). We note, however, that very few cases involving information of this sort were present in our dataset. Only $3 \%$ of the cases included in the full sample involve information likely to cause bodily injury and $8 \%$ of the cases involve information likely to lead to property damage. Therefore, the num-

\footnotetext{
${ }^{133}$ See supra Section I.A.3.

${ }^{134}$ See supra Section I.A.4.
} 
ber of these sorts of cases might be too small to accurately identify the effect of these variables on the likelihood of mandated disclosure.

Again we performed simple counts, the results of which shed light on whether courts are more likely to require disclosure of information regarding defects likely to cause physical injury or property damage. The results do not support our hypothesis that courts are more likely to require disclosure of this sort of information. Of the 12 cases involving information likely to result in physical injury, 8 (or $67 \%$ ) resulted in a finding that the informed party had a duty to disclose, while 4 (or $33 \%$ ) resulted in a finding that the informed party did not have a duty to disclose. Likewise, in $64 \%$ of cases (or 23 of 36) involving information likely to result in property damage, the court found a duty to disclose. On the other hand, courts required disclosure in about $50 \%$ (or 443 of 884 ) of cases not involving such information. While these results suggest that courts tend to rule for the uninformed party more often when bodily injury or property damage is involved, these case outcomes are not nearly as striking as one might expect, given the statements of legal commentators.

As with the INTRINSIC variable, an interesting question here is why so few decisions involve information that could prevent bodily injury or property damage. One possibility is that these cases settle, because the plaintiff (who, by definition, has suffered bodily injury or property damage) seems sympathetic and the defendant's behavior appears more egregious in comparison. In addition, it might be that cases of this sort give rise to other claims, such as negligence, and lawyers representing injured parties simply might not include additional claims for fraudulent silence. For example, a manufacturer's failure to disclose certain defects is actionable under state statutes related to products liability. Finally, it is possible that failures to disclose information regarding defects likely to lead to injuries or property damage simply occur with lower frequency than nondisclosures of other types of information. Obviously, we cannot test this conjecture using our data. 
5. Courts are significantly more likely to require disclosure when the withheld information would have updated or corrected previously disclosed information.

We hypothesized that courts would be more likely to require disclosure when the undisclosed information would have updated or corrected previously disclosed information. ${ }^{135}$ The results presented in Table 4 support this claim. The coefficient on UP_CORR is positive and highly significant $(p=0.01)$ when we control for all variables relating to case characteristics. In this case it appears that the commentators have argued correctly that this factor significantly influences courts' decisions in fraudulent silence cases.

\section{B. The Type of Transaction}

Recall that commentators have argued that the type of transaction in question influences courts' decisions in fraudulent silence cases. In particular, claims have been made that courts are more likely to require disclosure in transactions between parties in a confidential or fiduciary relationship; transactions concerning the acquisition of insurance, surety, or a release from liability; transactions in which the parties have unequal access to information; transactions concerning the transfer of real property; and transactions concerning the sale or transfer of a slave. ${ }^{136}$

\section{Courts are significantly more likely to require disclosure when the contracting parties are in a confidential or fiduciary relationship.}

We hypothesized that courts would be more likely to require disclosure when the contracting parties are in a confidential or fiduciary relationship. ${ }^{137}$ The results presented in Table 4 support this claim. The coefficient on CONFID is positive and highly significant $(p=0.00)$, even when we control for all variables relating to case characteristics. In this case it appears that the commentators have correctly argued that, when the parties are in a confidential or fiduciary relationship, courts are more likely to require disclosure.

\footnotetext{
${ }^{135}$ See supra Section I.A.5.

${ }^{136}$ See supra Section I.B.

${ }^{137}$ See supra Section I.B.1.
} 
2. Whether the transaction concerned insurance or a release from liability does not explain the variation in case outcomes, most likely because the number of cases involving such a transaction is too small to obtain useful results from regression analysis. Outcome counts, however, suggest that our hypotheses regarding information of this sort are not supported strongly by the data.

We hypothesized that decisions involving transactions related to insurance, surety, or a release from liability were more likely to result in the imposition of disclosure duties. ${ }^{138}$ We coded INSURANCE and RELEASE separately. Because only one case in our sample involved surety, we coded it as an insurance case. The independent variable INSURE therefore represents cases related to insurance and one case related to surety. RELEASE represents cases related to releases from liability.

The results presented in Table 4 indicate that the coefficients on INSURE and RELEASE are insignificant ( $p>0.10$ in all cases). We note again, however, that there are very few decisions involving information of this sort. Only $7 \%$ of the cases included in the full sample involve insurance transactions and only $3 \%$ of the cases involve releases from liability. Therefore, the number of these sorts of cases might be too small to accurately identify the effect of these variables on the likelihood of mandated disclosure.

Again, we used simple outcome counts to determine whether courts are more likely to require disclosure of information when the transaction involves insurance or a release from liability. The results do not support our hypothesis that courts are more likely to require disclosure of this sort of information. Of the 32 cases involving insurance contracts, the court found a duty to disclose in 20 (or $63 \%$ ). Likewise, courts found a duty to disclose in 9 of 15 cases (or $60 \%$ ) involving releases from liability. Therefore, while courts tend to find a duty to disclose in a somewhat slight majority of cases involving insurance or releases from liability, courts do not force disclosure in an overwhelming number of such cases.

3. Courts are significantly more likely to require disclosure when the transaction was one in which the parties had unequal access to information. Our analysis, however, indicates that the presence of

${ }^{138}$ See supra Section I.B.2. 
unequal access in combination with the casual acquisition of information actually drives case outcomes.

Recall from Part I that one of the liveliest debates in this literature is whether unequal access to information has a significant influence on the probability that courts will require the disclosure of material information. ${ }^{139}$ Of particular interest has been the debate between proponents of the equal access theory and proponents of the deliberately acquired information theory. ${ }^{140}$ The results reveal that if the parties had unequal access to the undisclosed information, courts are more likely to find that the informed party had a duty to disclose. The coefficient on ACCESS is positive and highly significant $(p=0.00)$, even when we control for all variables relating to case characteristics.

To ensure fair testing of the equal access theory we ran two additional regressions. First, Professor Scheppele's assertions about the state of the law were published in 1988. Accordingly, if changes in the law caused courts to decide fraudulent silence cases differently after 1988, a regression on our full dataset might fail to support the equal access theory, even if Scheppele's assertions were correct when made. To test this possibility, we ran a second regression using only cases decided from 1793 to 1987 . Under this specification, the coefficient on ACCESS remains positive and highly significant $(p=0.008 ; n=264)$.

Second, it is possible that Professor Scheppele actually was reporting a perceived trend in the law based on a reading of several recent, important cases that she believed signaled a development in existing law. If this is the case, then a regression on cases decided up to the date of her statements would not pick up that trend, as the small number of recent, important cases would be outweighed by the larger number of older cases decided under the prior rule of law. To test this possibility we ran a third regression using only cases decided from 1989 to 2002 . Under this specification, the coefficient on ACCESS is insignificant $(p=0.17 ; n=190)$, indicating

\footnotetext{
${ }^{139}$ See supra Section I.B.3.

${ }^{140}$ Compare Scheppele, supra note 2, at 124 (arguing that outcomes in fraudulent silence cases are best explained by the equal access theory), with Kronman, supra note 1 , at 2 (arguing that outcomes in fraudulent silence cases are best explained by the fact that some information is casually acquired and some information is deliberately acquired).
} 
that, in later cases, unequal access to information is not a driving force behind decisions on the duty element. Therefore, our data do not support the possibility that Scheppele was reporting a perceived trend or change in the law.

Our results thus shed light on this long-standing debate and, at least initially, lend some support to the proponents of the equal access theory. Particularly when viewed in light of the results on cases involving casually acquired information, ${ }^{141}$ our analysis seems to support the equal access proponents as opposed to those who claim that judges primarily consider economic efficiency in deciding case outcomes.

Because Professor Scheppele relied on many of the same cases employed by Professor Kronman to develop her theory, we thought it probable that both unequal access and casually acquired information were present in those cases requiring disclosure that the two authors examined. In other words, we surmised that both Kronman and Scheppele may have looked at a particular set of cases in which disclosure was required, the information was casually acquired, and the parties had unequal access. Whereas Kronman concluded that the casually acquired nature of the information drove case outcomes, Scheppele concluded that it was the unequal access of the parties that affected case outcomes. In contrast, we hypothesized that perhaps it is the presence of unequal access and casually acquired information together, rather than either factor separately, that actually drives case outcomes.

To test this claim, we used a logistic regression and included all twenty variables representing case characteristics and an interaction term, CASUAL * ACCESS. ${ }^{142}$ When we include this interaction term, we find that the coefficient on the interaction term is statistically significant and positive $(p=0.04)$. At the same time, the

\footnotetext{
${ }^{141}$ See infra Section III.C.

${ }^{142}$ The variable ACCESS and the interaction term (CASUAL * ACCESS) are strongly positively correlated $(r=0.80)$. Therefore, we checked for problems related to multicollinearity. When we regress ACCESS on all the other independent variables and CASUAL * ACCESS, the tolerance is equal to 0.19 . This means that $19 \%$ of the variation in the ACCESS variable is not explained by the other independent variables. We get a similar measure of tolerance when we regress the interaction term on all the independent variables. Tolerances of $5 \%$ or less are cause for concern. Thus, we are confident that our results are not significantly affected by multicollinearity.
} 
coefficients on CASUAL and ACCESS both become insignificant ( $p=0.86$ and $p=0.72$, respectively).

These results suggest that courts are more likely to find a duty to disclose when both of these factors are present, but not when either is present alone. Accordingly, our analysis indicates that each side of this heated debate is both right and wrong at the same time. Although whether the parties to the transaction had equal access to information and whether the informed party casually acquired the information both impact the probability that a court will mandate disclosure, as suggested by participants in the debate, only the presence of both factors together significantly impacts case outcomes.

4. Whether the transaction involved the transfer of real property does not explain the variation in case outcomes when we control for all case characteristics.

As we discussed in Part I, some commentators claim that courts are more likely to require disclosure when the transaction involves the transfer of real property. ${ }^{143}$ The results presented in Table 4 indicate that the coefficient on PROPERTY is highly significant and positive $(p=0.00)$ when we control only for variables relating to the type of transaction. When we control for all case characteristics, however, the coefficient loses significance. When all variables related to case characteristics are included in the model the coefficient on PROPERTY becomes insignificant $(p>0.10)$, indicating that courts' decisions in cases involving the transfer of real property are actually driven by other variables that are present in these sorts of cases.

To test the most obvious potential variables driving the real property cases, we ran two logistic regressions that included all twenty variables related to case characteristics and an interaction term for either PROPERTY * LATENT or PROPERTY* BUYER. In both cases, the interaction term was insignificant, meaning that neither LATENT nor BUYER drives the outcomes in property cases. Additional research is required to understand the interactions between PROPERTY and the other variables.

\footnotetext{
${ }^{143}$ See supra Section I.B.4.
} 
5. Three cases involving the sale or transfer of a slave appear in the dataset, and in each case the court found that the informed party had a duty to disclose. We dropped the variable SLAVE from the regression analysis because it is a perfect predictor of case outcome.

Although we predicted in Part I that courts are more likely to impose disclosure duties in cases involving the sale or transfer of a slave ${ }^{144}$ we were not able to test this claim using regression analysis to control for the effects of other case characteristics because SLAVE is a perfect predictor of whether the court required disclosure. In all three cases involving the sale or transfer of a slave, the court held that the informed party had a duty to disclose. Therefore, although only three cases in our sample involve the sale or transfer of a slave, the fact that all three require disclosure is at least consistent with claims by some commentators that courts vigilantly police such transactions.

\section{How the Information Was Acquired}

As discussed in Part I, commentators also argue that the method the informed party used to acquire the undisclosed information influences the likelihood that courts will impose a duty to disclose on parties to a transaction. In particular, commentators have argued that courts more frequently require the disclosure of casually acquired information and information acquired through illegal or tortious means. ${ }^{145}$

1. The results provide very weak support, if any, for the claim that courts are more likely to require the disclosure of casually, as opposed to deliberately, acquired information. Our analysis, however, indicates that, if the parties lacked equal access to the information and the information was acquired casually, courts are more likely to require disclosure. ${ }^{146}$

a. General Results

Recall from Part I that Professor Kronman contends that courts hesitate to require the disclosure of information deliberately ac-

\footnotetext{
${ }^{144}$ See supra Section I.B.5.

${ }^{145}$ See supra Section I.C.

${ }^{146}$ See supra note 142 and accompanying text (discussing the interaction of ACCESS with CASUAL).
} 
quired by the informed party. ${ }^{147}$ We predicted that, although distinguishing between deliberately acquired and casually acquired information is difficult in practice, the presence of this factor influences courts to find a duty to disclose in fraudulent silence cases.

The results presented in Table 4 are mixed on this factor. When we control only for factors relating to how the information was acquired, the coefficient on CASUAL is insignificant $(p=0.71)$. When we control for all case characteristics, however, the coefficient becomes positive and weakly significant $(p=0.06)$, suggesting that courts might be more likely to require disclosure when the information is casually acquired as opposed to deliberately acquired.

It is important to note here that the result related to this variable is not robust to other specifications that include variables for the year in which the case was decided, the geographic region in which the court sits, and the jurisdiction of the court. ${ }^{148}$ As presented in Table 6, when we control for the case characteristics and (1) the decision year, or (2) the geographic region, or (3) whether the court is a state or federal court, the coefficient on CASUAL remains positive and weakly significant $(0.10>p>0.05)$. When we control for (1) the case characteristics together with the circuit in which the court sits, or (2) all independent variables that we coded, however, the coefficient on CASUAL becomes insignificant $(p>0.10)$. These results indicate that the explanatory power of CASUAL is not robust to changes in the specification, which suggests that any possible influence of CASUAL on the likelihood that the court will impose a duty to disclose is weak at best.

To ensure a fair test of Professor Kronman's claims, we ran two additional regressions. First, Kronman developed his theory based on an examination of the law in 1978. As a result, if a change in the law of fraudulent silence caused courts to decide cases differently after 1978, then a regression on the full dataset could unfairly reject Kronman's hypothesis. Accordingly, we ran a second regression using only cases decided prior to the publication of his theory,

\footnotetext{
${ }^{147}$ See supra notes 65-75 and accompanying text (discussing the Kronman theory). As previously noted, Professor Kronman limits his claims to socially productive information, a distinction that we find irrelevant for the purposes of this study. See supra note 65 (discussing this fact).

${ }^{148}$ General results for specifications including these additional variables are presented infra in Sections III.F and III.G.
} 
Table 6

Maximum-Likelihood Logit Estimation Results Including Year, Region, and Jurisdiction Dependent Variable: Predicted Log Odds of Court Finding Duty to Disclose

INDEPENDENT VARIABLES

Type of Information: INTRINSIC

COEFFICIENT

\begin{tabular}{|c|c|c|c|c|c|c|c|}
\hline Type of Information: & INTRINSIC & $\begin{array}{c}0.16 \\
(0.86)\end{array}$ & $\begin{array}{c}0.49 \\
(0.60)\end{array}$ & $\begin{array}{l}-0.04 \\
(0.96)\end{array}$ & $\begin{array}{c}0.12 \\
(0.90)\end{array}$ & $\begin{array}{l}-0.23 \\
(0.82)\end{array}$ & $\begin{array}{c}0.13 \\
(0.99)\end{array}$ \\
\hline & PERSONAL & $\begin{array}{l}(0.00) \\
-0.32\end{array}$ & -0.22 & -0.30 & -0.18 & -0.35 & -0.29 \\
\hline & & $(0.56)$ & $(0.69)$ & $(0.60)$ & $(0.76)$ & $(0.56)$ & $(0.63)$ \\
\hline & LATENT & $2.24 \mathrm{~m}$ & $2.09^{*+4}$ & $2.37 *$ & $2.23^{* * *}$ & $2.34 * * *$ & $2.27^{* * *}$ \\
\hline & & $(0.00)$ & $(0.00)$ & $(0.00)$ & $(0.00)$ & $(0.00)$ & $(0.00)$ \\
\hline & INJURE & 1.05 & 0.93 & 1.16 & 1.28 & 1.41 & 1.27 \\
\hline & & $(0.20)$ & $(0.27)$ & $(0.17)$ & $(0.13)$ & $(0.13)$ & $(0.19)$ \\
\hline & DAMAGE & -0.23 & 0.03 & -0.27 & -0.16 & -0.29 & -0.14 \\
\hline & & $(0.72)$ & $(0.97)$ & $(0.69)$ & $(0.81)$ & $(0.68)$ & $(0.84)$ \\
\hline & UP_CORR & $1.06 * *$ & $1.12^{* *}$ & $1.13^{* *}$ & $1.14^{* *}$ & $1.26^{* *}$ & $1.29 * *$ \\
\hline & - & $(0.01)$ & $(0.01)$ & $(0.01)$ & $(0.01)$ & $(0.01)$ & $(0.01)$ \\
\hline Type of Transaction: & CONFID & $2.65 * * *$ & $2.42 * * *$ & $2.84 * \cdots$ & $2.50^{* * * *}$ & $2.68^{* * *}$ & $2.70^{*+\infty}$ \\
\hline & & $(0.00)$ & $(0.00)$ & $(0.00)$ & $(0.00)$ & $(0.00)$ & $(0.00)$ \\
\hline & INSURE & -0.13 & -0.24 & -0.01 & -0.11 & $\begin{array}{l}-0.21 \\
0.760\end{array}$ & $\begin{array}{l}-0.23 \\
(0.75)\end{array}$ \\
\hline & RELEASE & $\begin{array}{c}(0.84) \\
0.51\end{array}$ & $\begin{array}{c}(0.71) \\
0.47\end{array}$ & $\begin{array}{c}(0.99) \\
0.51\end{array}$ & $\begin{array}{c}(0.86) \\
0.38\end{array}$ & $\begin{array}{c}(0 . / 6) \\
0.36\end{array}$ & 0.35 \\
\hline & RELEASE & $(0.55)$ & $(0.57)$ & $(0.58)$ & $(0.65)$ & $(0.68)$ & $(0.70)$ \\
\hline & ACCESS & $1.03^{* * *}$ & $1.05^{* * *}$ & $1.03 * * *$ & $1.1 I^{* \cdots *}$ & $1.24^{* * * *}$ & $1.20^{* * *}$ \\
\hline & & $(0.00)$ & $(0.00)$ & $(0.00)$ & $(0.00)$ & $(0.00)$ & $(0.00)$ \\
\hline & PROPERTY & 0.29 & 0.26 & 0.33 & 0.12 & -0.13 & -0.04 \\
\hline & & $(0.45)$ & $(0.50)$ & $(0.40)$ & (0.77) & $(0.76)$ & $(0.92)$ \\
\hline Type of Acquistition: & CASUAL & $0.76^{*}$ & $0.72^{*}$ & $0.81^{\circ}$ & $0.67^{*}$ & 0.53 & 0.52 \\
\hline & & $(0.06)$ & $(0.07)$ & $(0.05)$ & $(0.09)$ & $(0.21)$ & $(0.23)$ \\
\hline & ILLEGAL & 1.26 & 0.99 & 0.75 & 1.26 & 0.84 & 0.16 \\
\hline & & $(0.46)$ & $(0.55)$ & $(0.66)$ & (0.44) & $(0.66)$ & $(0.93)$ \\
\hline Uninformed & BUYER & $1.18^{* * *}$ & $1.25^{* * *}$ & $1.33 * \ldots *$ & $1.20^{* * *}$ & $1.53^{*+*}$ & $1.72^{* * *}$ \\
\hline Party & & $(0.00)$ & $(0.00)$ & $(0.00)$ & $(0.00)$ & $(0.00)$ & $(0.00)$ \\
\hline Characteristics: & FEMALE & 0.04 & 0.03 & 0.20 & -0.04 & -0.02 & 0.17 \\
\hline & & $(0.93)$ & $(0.94)$ & $(0.67)$ & $(0.93)$ & $(0.97)$ & $(0.74)$ \\
\hline & SICK & $1.58 * *$ & $\begin{array}{l}1.42^{*} \\
(0.05)\end{array}$ & $\begin{array}{l}1.66 * * \\
(0.03)\end{array}$ & $\begin{array}{l}1.58 * * \\
(0.03)\end{array}$ & $\begin{array}{l}1.72^{* *} \\
(0.03)\end{array}$ & $\begin{array}{l}1.56^{*} \\
(0.06)\end{array}$ \\
\hline Informed & LIED & $3.17 * *$ & $3.17^{* * *}$ & $3.22 * * *$ & $3.23 * *$ & $3.49 * * *$ & $3.52^{* * *}$ \\
\hline Party & & $(0.00)$ & $(0.00)$ & $(0.00)$ & $(0.00)$ & $(0.00)$ & $(0.00)$ \\
\hline Characteristics: & CONCEAL & $3.15 * * *$ & $3.32 * * *$ & $3.31^{* * *}$ & $3.27^{*+*}$ & $3.44^{* * *}$ & $3.65 * *$ \\
\hline & & $(0.00)$ & $(0.00)$ & $(0.00)$ & $(0.00)$ & $(0.00)$ & $(0.00)$ \\
\hline & HALF_TRUTH & $2.81 * * *$ & $2.69 * * * *$ & $2.87 * * *$ & $2.73^{* *}$ & $2.91^{*}$ & $2.88^{* * *}$ \\
\hline & & $(0.00)$ & $(0.00)$ & $(0.00)$ & $(0.00)$ & $(0.00)$ & $(0.00)$ \\
\hline Time Trend: & YEAR & & $\begin{array}{c}-0.01 * * * \\
(0.01)\end{array}$ & & & & $\begin{array}{c}-0.01^{*} \\
(0.08)\end{array}$ \\
\hline Geographic Region: & WEST & & & 0.68 & & & 0.45 \\
\hline & SOITH & & & (0.17) & & & $\begin{array}{l}(0.42) \\
0.20\end{array}$ \\
\hline & SOUTH & & & $\begin{array}{l}0.19 \\
(0.67)\end{array}$ & & & $(0.69)$ \\
\hline & MID-ATLANTIC & & & $1.13 * *$ & & & $0.97 *$ \\
\hline & & & & $(0.01)$ & & & $(0.07)$ \\
\hline & SOUTHWEST & & & $1.35 *$ & & & $1.22^{*}$ \\
\hline & & & & $(0.03)$ & & & $(0.07)$ \\
\hline & NEW ENGLAND & & & 0.67 & & & 0.58 \\
\hline & & & & $(0.26)$ & & & $(0.37)$ \\
\hline Jurisdiction: & STATE & & & & $0.75^{* *}$ & & -1.39 \\
\hline & & & & & $(0.04)$ & & $(0.28)$ \\
\hline & 3RD CIRCUIT & & & & & $\begin{array}{l}-1.20 \\
(0.26)\end{array}$ & $\begin{array}{c}-2.86^{*} \\
(0.08)\end{array}$ \\
\hline & 6TH CIRCUIT & & & & & $-3.20 * *$ & $-4.70^{* *}$ \\
\hline & & & & & & $(0.02)$ & $(0.02)$ \\
\hline & 7TH CLRCUIT & & & & & $\begin{array}{l}-2.90 * * \\
(0.02)\end{array}$ & $\begin{array}{l}-3.74 * 0 \\
(0.05)\end{array}$ \\
\hline Controls for all circuit & included $^{\dagger}$ & & & & & YES & YES \\
\hline & Constant & $-4.41 * * *$ & $13.55^{*}$ & $-5.03 * * *$ & $-4.84 * * *$ & $-3.86^{* * * *}$ & 11.09 \\
\hline & & $(0.00)$ & $(0.06)$ & $(0.00)$ & $(0.00)$ & $(0.00)$ & $(0.19)$ \\
\hline & $\operatorname{LR} \chi^{2}$ & 310.58 & 317.23 & 321.20 & 314.91 & 325.54 & 337.22 \\
\hline & & $(0.00)$ & $(0.00)$ & $(0.00)$ & $(0.00)$ & $(0.00)$ & $(0.00)$ \\
\hline & Pseudo $\mathrm{R}^{2}$ & 0.48 & 0.49 & 0.50 & 0.49 & 0.52 & 0.53 \\
\hline & $\mathbf{N}$ & 463 & 463 & 463 & 463 & 456 & 456 \\
\hline
\end{tabular}

${ }^{*} p<0.10 ; * * p<0.05 ; * * * p<0.01$

$\dagger$ Ouly those circuits for which results are statistically significant at the $10 \%$ level appear in the table. 
TABLE 6: This table provides the maximum-likelihood logit estimation results for the effects of case characteristics, including the decision date, geographic location of the court (Midwest used as base) and jurisdiction of the court, on whether the court found a duty to disclose.

Note: LR $\chi 2$ indicates the result from testing the null hypothesis that all coefficients in the model, except the constant, equal zero. In addition, it should be noted that, although pseudo $\mathbf{R}^{2}$ statistics provide a quick way to compare the fit of different models for the same dependent variable, they lack the straightforward explained-variance interpretation of true $R^{2}$ in OLS regression.

from 1793 to 1977 . In this specification, which controls only for the case characteristics and not year of decision, jurisdiction, or geographic region, the coefficient on CASUAL remains positive and weakly significant $(p=0.08 ; n=204)$.

Second, Professor Kronman actually may have been reporting a perceived trend or change in the law based on the outcomes of a few recently decided, important cases that he believed signaled a change in existing law. If this is true, then a regression on cases decided up to the time Kronman made his statements would not pick up this trend, because the many older cases following the prior rule of law would obscure the impact of the more recent, important cases asserting a new rule of law. To test this possibility, we ran a regression using only cases decided after the publication of his theory, from 1979 to 2002 . In this specification, again controlling only for case characteristics, the coefficient on CASUAL becomes insignificant $(p=0.22 ; n=255)$, indicating that whether the information was casually, rather than deliberately, acquired has no signifi cant influence on whether the court finds a duty to disclose in the later cases. Therefore, our data do not support the claim that Kronman was reporting a perceived trend or change in the law.

\section{b. Assumptions Regarding the Means of Information Acquisition}

Recall that Professor Kronman contends that, because it is inefficient for courts to make case-by-case determinations of whether information is casually or deliberately acquired, courts instead lay down blanket rules about what class of case is most likely to involve deliberately or casually acquired information. In contrast, we coded cases on an individual basis by analyzing the specific facts of each case. Accordingly, our study was not designed to test precisely Kronman's hypothesis. 
Nonetheless, coding in this manner allows us to test whether Professor Kronman was correct in his assumptions about how certain types of information are normally acquired. Recall, for example, Kronman's assertion that whether information is extrinsic or intrinsic appears to be relevant to court decisions only because extrinsic information is typically deliberately acquired, and courts are concerned with protecting parties who have deliberately acquired their information. ${ }^{149}$ To test the claim that extrinsic information is typically deliberately acquired we performed simple counts. Of the 14 cases in our dataset that involve extrinsic information, 8 (or $57 \%$ ) involve information that was casually acquired. Although this relies upon a very small sample size, this result contradicts Kronman's characterization of the typical method of acquiring extrinsic information.

Similarly, Professor Kronman asserts that whether the transaction concerned the transfer of real property appears to be relevant to courts only because information relevant to the transfer of real property is typically casually acquired, and courts are more likely to require the disclosure of casually acquired information. To test the claim that information relevant to the transfer of real property is typically casually acquired, we performed simple counts. Of the 157 cases in our dataset that involve information concerning the transfer of real property, 124 (or $79 \%$ ) involve casually acquired information. In this instance, Kronman's hypothesis about the manner of information acquisition appears largely correct.

Finally, Professor Kronman argues that whether a defect is latent or patent appears to drive case outcomes only because information concerning a latent defect is typically casually acquired, and courts require the disclosure of casually acquired information. To test the claim that information concerning a latent defect is typically acquired casually, we performed simple counts. Of the 60 cases in our dataset that involve information concerning a latent defect, 54 (or $90 \%$ ) involved casually acquired information. In this instance, again, Kronman's prediction about the method by which such information is acquired seems accurate.

Of course, these results do not take into account cases that are not ultimately decided by the court, and there is reason to believe

\footnotetext{
${ }^{149}$ See supra notes $65-67$ and accompanying text.
} 
that claims that settle or are never filed are different in important ways from claims that result in decisions. Without access to this information, we are not able to adequately evaluate Professor Kronman's claims about the likely means of information acquisition in all cases.

2. Whether the information was acquired through illegal or tortious means does not explain the variation in case outcomes because the number of cases involving such information is too small to obtain useful results from regression analysis. Outcome counts provide limited support for the hypothesis that courts are more likely to impose disclosure duties on contracting parties when the information is acquired through illegal or tortious means.

We hypothesized that courts are more likely to hold that the informed party owes the uninformed party a duty to disclose when the informed party acquires information using illegal or tortious means. ${ }^{150}$ The results presented in Table 4 demonstrate that the coefficient on ILLEGAL is insignificant $(p>0.10)$, indicating that this factor does not help to explain the variation in case outcomes. This result is most likely driven by the fact that only $1 \%$ of the cases in the full sample involve information of this sort. The number of these sorts of cases might be too small to accurately identify the effect of this variable on the likelihood of mandated disclosure.

Nonetheless, simple outcome counts provide weak support for our hypothesis relating to the disclosure of illegally acquired information. Of the 4 cases in the sample involving information acquired illegally or tortiously, 3 cases (or $75 \%$ ) resulted in the imposition of liability for fraudulent silence. The results of the outcome count thus provide some support for the claim that courts are more likely to impose a duty to disclose on the informed party when the withheld information is acquired illegally or tortiously, although the support is weak given that our sample includes a very small number of such cases.

As with the other independent variables that appear in relatively few cases, a relevant question is why so few cases involving information acquired by illegal or tortious means result in decisions. One possibility is that such cases settle early because the defendant

${ }^{150}$ See supra Section I.C.2. 
is unsympathetic (having violated the law or committed a tort). Accordingly, such defendants might fear that courts will treat them more harshly, and would prefer to avoid the costs and potential bad publicity associated with litigation. If true, this fear regarding the impact of the informed party's behavior on the case outcome is consistent with our findings regarding court decisions when the informed party has engaged in other types of bad behavior, such as concealing information, lying, or telling a half-truth. ${ }^{151}$

\section{Characteristics of the Uninformed Party}

As discussed in Part I, we hypothesized that court decisions are influenced by particular characteristics of the uninformed party, including whether the uninformed party is a buyer or lessee; is female; or is sick, disabled, illiterate, elderly, or otherwise severely disadvantaged in the bargaining relationship, although still competent to contract. ${ }^{152}$

1. Courts are significantly more likely to require disclosure when the uninformed party is the buyer or lessee.

We hypothesized that courts would be more likely to require disclosure when the uninformed party is the buyer or lessee, as opposed to the seller. ${ }^{153}$ The results presented in Table 4 support this claim. The coefficient on BUYER is positive and highly significant $(p \leq 0.01)$, even when we control for all variables relating to case characteristics. In this case, it appears that the commentators have argued correctly that courts impose higher disclosure duties on sellers than on purchasers.

\footnotetext{
${ }^{151}$ See infra Section III.E (discussing the impact of the informed party's behavior on case outcomes).

${ }^{152}$ See supra Section I.D.

${ }^{153}$ See supra Section I.D.1.
} 
2. Whether the uninformed party was female does not seem to be a factor that influences courts' decisions regarding fraudulent silence. However, the percentage of cases in which the uninformed party is female and disclosure is required decreased significantly from the period 1793-1950 to the period 1951-2002. ${ }^{154}$

As discussed in Part I, we hypothesized that a duty to disclose information is more likely to be found when the uninformed party is female, especially in older cases. The results presented in Table 4, however, indicate that the coefficient on FEMALE is insignificant $(p>0.10)$ in all specifications. These results suggest that courts are not significantly influenced by the gender of the uninformed party when determining the disclosure duties of bargaining parties.

To test whether courts' positions with respect to the level of disclosure required by the informed party when the uninformed party is female changed over time, we performed simple counts. Prior to 1950,24 cases involved an uninformed party who was female, and 20 cases (or $83 \%$ ) required disclosure. In contrast, in the period from 1950 to May 15, 2002, 31 cases involved an uninformed party who was female and 13 cases (or $42 \%$ ) required disclosure. A test of the equality of proportions indicates that this difference is statistically significant $(p=0.001)$. Although, when we control for all other variables relating to case characteristics, FEMALE does not seem to influence court decisions, we do find that in cases in which the uninformed party is feinale, courts were much more likely to require disclosure in cases decided prior to 1950 than in post-1950 cases.

\footnotetext{
${ }^{154}$ We chose to divide the dataset into these time periods for specific reasons, including that the split resulted in roughly equal sample sizes of cases involving uninformed females, and that public perceptions regarding the competence of women involved in commercial and business transactions may have begun to change during this postWorld War II era.
} 
3. Courts are statistically significantly more likely to require disclosure when the uninformed party was sick, disabled, illiterate, or elderly, though competent to contract, although the statistical significance of the influence of this variable varies with the specification of the statistical model.

As discussed in Part I, we hypothesized that courts express sympathy for uninformed parties who are sick, disabled, illiterate or elderly, though still competent to contract, by being more likely to rule in their favor because of these factors. ${ }^{155}$ The results presented in Table 4 support this claim. The coefficient on SICK is positive and significant $(p \leq 0.10)$ in all specifications. Note, however, that the significance of the coefficient varies with the specification; in some cases the coefficient is statistically significant at only the $10 \%$ level (for example, Table 6 indicates a $p$-value of 0.06 when we control for all case characteristics, case decision year, geographic region and jurisdiction). Although the evidence is weak for some specifications of the empirical model, our intuition that when the uninformed party is sympathetic in these particular ways courts are more likely to require disclosure appears to have been correct.

\section{E. Behavior of the Informed Party}

As discussed in Part I, we hypothesized that courts consider the general behavior of the informed party when deciding the extent to which secret information must be disclosed to the uninformed party. Specifically, we predicted that when the informed party made affirmative misrepresentations or told half-truths in the same transaction in which the alleged omission occurred and when the informed party actively concealed information, courts are more likely to find a duty to disclose. ${ }^{156}$

1. Courts are more likely to require disclosure if the court finds that the informed party made affirmative misrepresentations or told halftruths in the same transaction in which the alleged omission occurred.

In Part I, we predicted that courts' decisions regarding whether material information must be revealed to the uninformed party are

\footnotetext{
${ }^{155}$ See supra Section I.D.3.

${ }^{156}$ See supra Section I.E.
} 
influenced by the general behavior of the informed party. ${ }^{157}$ Specifically, if the informed party was found to have made an affirmative misrepresentation or told a half-truth to the uninformed party in the same transaction in which the alleged omission occurred, we hypothesized that the court would be more likely to rule against the informed party in the separate fraudulent silence claim. The results presented in Table 4 support both of these claims. The coefficients on LIED and HALF-TRUTH are positive and highly significant $(p=0.00)$. When we control for the case decision year, the geographic region, and the jurisdiction of the court, the coefficients remain positive and highly significant $(p=0.00)$. Therefore, the data provide strong support for the prediction that the general bad behavior of the informed party influences courts.

\section{A court is more likely to find a duty to disclose if it finds that the informed party actively concealed the withheld information.}

As discussed in Part I, we also hypothesized that another form of bad behavior on the part of the defendant - the active concealment of information-increases the probability that the court will require disclosure. ${ }^{158}$ The results presented in Table 4 support this claim. The coefficient on CONCEAL is positive and highly significant $(p=0.00)$. When we control for the case decision year and the geographic region and jurisdiction of the court, the coefficient remains positive and highly significant $(p=0.00)$. Therefore, the data provide strong support for the claim that actions taken by the informed party to conceal information influence courts' decisions regarding the imposition of disclosure duties. When taken together with the findings on LIED and HALF-TRUTH discussed in Section III.E.1. above, the data strongly support the theory that courts account for the informed party's behavior in determining whether a duty to disclose existed.

\section{F. Case Date}

Recall from Part I that many commentators argue that courts have become more pro-disclosure during the time period over

\footnotetext{
${ }^{157}$ See supra Section I.E.1.

${ }^{158}$ See supra Section I.E.2.
} 
which our data span. In addition, some commentators make more specific claims about changes in the doctrine or application of the doctrine over time. ${ }^{159}$ In this Section we investigate these claims about trends over time and discuss some interesting patterns in the data revealed by our study.

\section{Basic regression analyses do not support the claim that courts have become more likely to require the disclosure of material information over time.}

Table 6 presents results from tests of the influence of the case decision date on the likelihood that the court will rule that the informed party had a duty to disclose the withheld information to the uninformed party. ${ }^{160}$

The results related to the general trend over time are striking. First, while most commentators claim that courts are more likely to require disclosure in more recent cases, results generated by the logistic regression analysis reported in Table 6 suggest that courts are less likely to mandate disclosure in recently decided cases. When we control for all twenty case characteristics, the coefficient on YEAR is negative and statistically significant $(p=0.01)$, indicating that, over time, courts have become less likely to find a duty to disclose. To test the robustness of this result, we added controls for geographic region and jurisdiction of the court. ${ }^{161}$ Although the coefficient loses some of its significance, it remains negative and weakly statistically significant $(p=0.08)$.

Although these results provide support for the claim that courts have become less likely over time to require the disclosure of material information, testing the claim using regression analysis does not allow us to determine whether this development progresses in

\footnotetext{
${ }^{159}$ See supra notes $96-97$ and accompanying text.

${ }^{160}$ We also analyzed the data using probit analysis and obtained results that were nearly identical to the results we obtained using logistic regression analysis.

${ }^{161}$ Adding controls allows us to determine whether the relationship between year and the probability that the court imposes a duty to disclose suggested by the initial regression might be attributable to some other variable (for example, geographic region or jurisdiction) that possibly is correlated with year. For example, if a particular jurisdiction is less likely than other jurisdictions to find a duty to disclose and this jurisdiction produces a larger portion of reported case outcomes over time, then by controlling for jurisdiction the regression is able to untangle the influences of jurisdiction and year of decision on the likelihood that the court will impose a disclosure duty.
} 
a linear fashion or is more complicated, with spikes and valleys during particular time periods. To investigate this possibility, we employed more nuanced statistical tests and constructed timeseries graphs.

2. Simple tabulation results do not support the claim that courts have been more likely to require disclosure in cases decided in later years.

We employed simple tabulations, the results of which are reported in Table 7, to check for differences between particular time periods using the entire sample.

Table 7

Tabulations for Cases over Various Periods

$\begin{array}{ccc}\text { PERIOD } & \begin{array}{c}\text { COURT FOUND } \\ \text { DUTY TO } \\ \text { DISCLOSE }\end{array} & \begin{array}{c}\text { COURT FOUND NO } \\ \text { DUTY TO } \\ \text { DISCLOSE }\end{array} \\ 1793-1860 & 10(67 \%) & 5(33 \%) \\ 1861-1940 & 89(71 \%) & 37(29 \%) \\ 1941-2002 & 138(42 \%) & 187(58 \%)\end{array}$

TABLE 7: This table presents the results of tabulations of the number of cases by outcome for three periods: $1793-1860,1861-1940$ and 1941-2002. See supra note 99 and accompanying text.

We found that, prior to 1860 , courts found a duty to disclose in 10 of 15 cases (or $67 \%$ ). Between 1861 and 1940, the years roughly between the Civil War and the start of World War II, courts found a duty to disclose in 89 of 126 cases (or $71 \%$ ). Finally, between 1941 and 2002, courts found a duty to disclose in 138 of 325 cases (or $42 \%$ ). A test for the equality of proportions calculated for the first two periods indicates that no statistically significant difference exists between the proportions $(p=0.62)$. The difference between the proportions calculated for the period 1861-1940 and 19412002 , however, is statistically significant $(p=0.00)$. These results do not support claims about an increase in the likehhood that courts will require disclosure due to the shift from an agrarian to a commercial economy. In fact, the data indicates the opposite-courts have been less likely to require the disclosure of material informa- 
tion from World War II to the present than they were during the period from the Civil War until World War II.

3. A time-series graph of the dependent variable does not support the claim that courts have been more likely over time to require informed parties to disclose information to uninformed parties, but reveals an interesting pattern when compared to a time series graph of the number of fraudulent silence decisions across time.

To better understand the pattern of court decisions over time, we graphed the proportion of fraudulent silence cases in which the court found that the informed party owed the uninformed party a duty to disclose (see Figure 1).

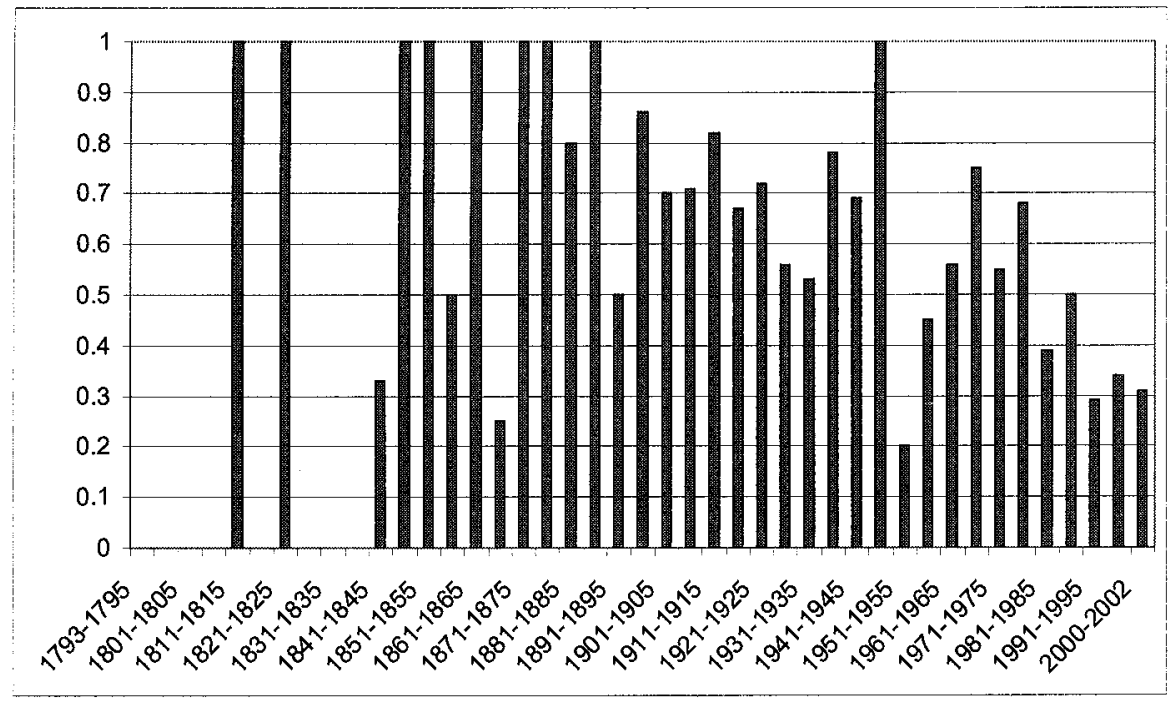

Figure 1: Proportion of Cases in Which the Court Found a Duty to Disclose by Year

The graph reveals that the proportion of cases in which the court imposed a duty of disclosure on the informed party decreased almost linearly over time, especially in the years after 1970-the years in which most of the cases in our dataset were decided. This observation further supports the findings obtained from the regression analyses. Given the pattern in the dependent variable over time revealed in Figure 1, it is unlikely that a non-linear relation- 
ship between time and the probability of the court requiring disclosure exists.

It is also interesting to note that the number of decisions involving the issue of whether the informed party owed a duty of disclosure significantly increased over time, again especially in the years after 1970. Figure 2 presents a graph of the number of fraudulent silence decisions by five-year periods. ${ }^{162}$ There are a small number of decisions during the five-year periods prior to 1900; therefore, we focus mainly on two trends in the data relating to the twentieth century.

${ }^{162}$ Recall that for the years prior to 1944 , all relevant cases were included in the dataset, whereas, for 1944 and subsequent years, a random sample of the cases was included in the dataset. The vertical line drawn in Figure 2 divides these periods. For this reason, the increase in the number of decided cases after 1944 is actually understated in Figure 2. 

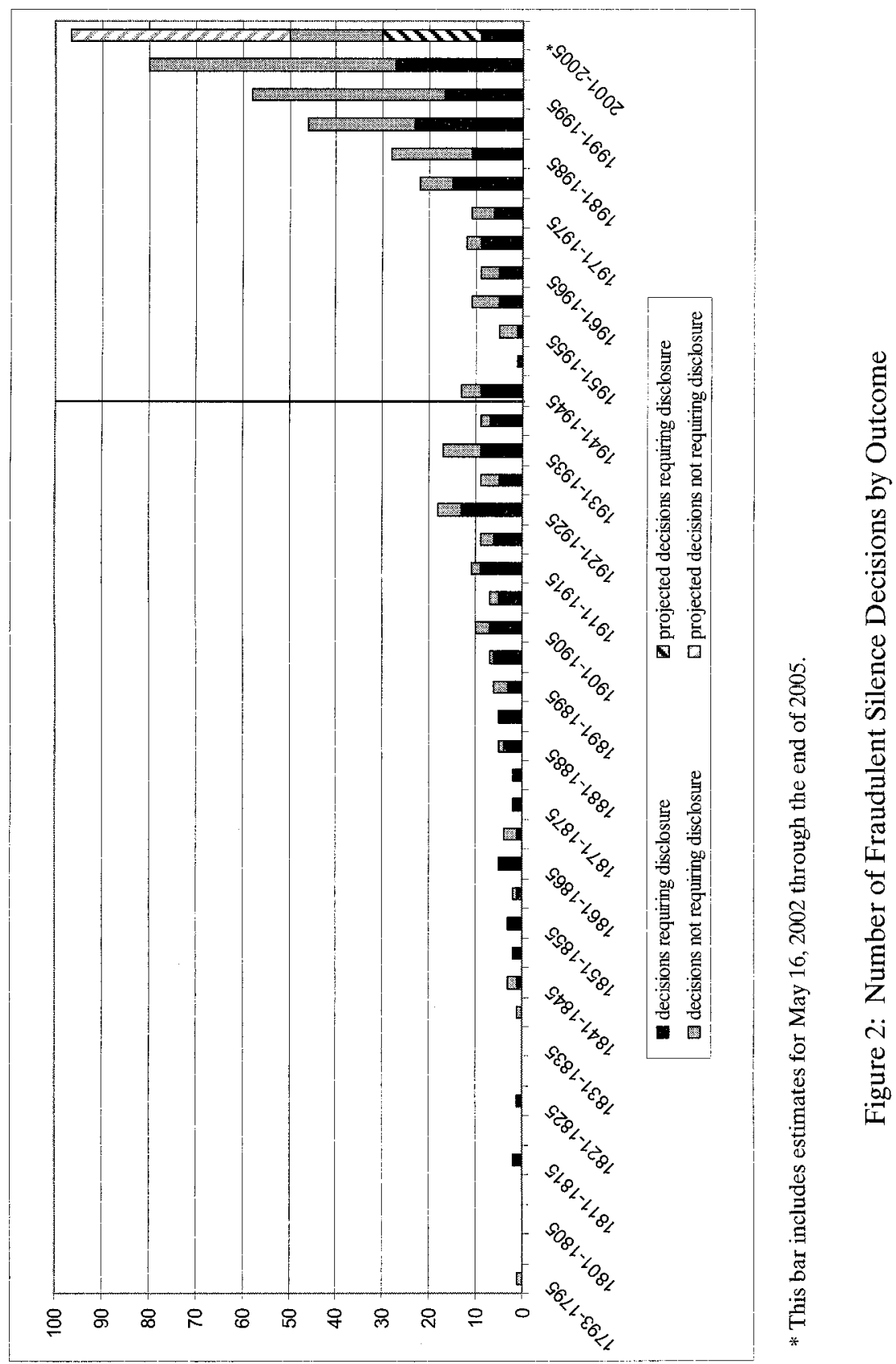
Recall that our dataset includes cases decided through May 15, 2002. The striped bars represent projections for the period May 15, 2002 , through 2005. The vertical line separates cases decided prior to 1944 , all of which are included in our dataset, from cases decided during or after 1944, a random sample of which is included in our dataset.

By examining Figures 1 and 2 simultaneously, we find that, especially in the years subsequent to 1970 , the courts become less likely to require disclosure, while, during the same period, a significantly increasing number of decisions appear in our dataset. On its face, this result seems counterintuitive. One might predict that, as the probability of winning at trial decreases, fewer uninformed parties will bring claims and more will settle prior to resolution by the court. $^{163}$

To explain this seemingly odd result, one would need information on filing behavior, settlement rates, whether statutes impact the types of cases decided under common law, whether the issues on which judges choose to write opinions change over time, and how disclosure rules affect individual decisions about whether to disclose information. Accordingly, any conjectures made here about what is driving these patterns are simply that - conjectures.

Nonetheless, one possibility is worth mentioning. Recall that the existence of a duty to disclose is only one element of a fraudulent silence case in which the plaintiff must prove other elements, such as scienter, reliance, and materiality, in order to prevail. If the increase in the number of fraudulent silence decisions actually reflects an increase in the number of such claims that are brought and survive to litigation at the same time that the plaintiff's probability of winning on the duty to disclose element is decreasing, then this could possibly reflect the fact that the plaintiff's probability of winning on one or more of the other elements of a fraudulent silence case (materiality, for example) is increasing at an even faster rate. Naturally, we are unable to test this conjecture using our data. Our study, however, raises the possibility that a similar

\footnotetext{
${ }^{163}$ We recognize the possibility that fewer cases are being filed and more cases make it to the decision stage as time goes on. Our data, however, do not allow us to investigate the relationship between the probability of the court imposing a duty to disclose on the informed party and the number of cases decided per year.
} 
study focusing on one or more of the other elements of a fraudulent silence case would reveal interesting time trends as well.

4. The time trend on the number of fraudulent silence decisions is in marked contrast to time trends on the number of decisions in contract cases generally.

In a 2001 study of contract litigation, Professor Marc Galanter found that the volume of trials in contract cases increased until 1990 , followed by a substantial decline by about one-third, culminating in a period of little change from year to year. ${ }^{164}$ Our data on fraudulent silence decisions follow a markedly different pattern. Rather than decreasing during the period after 1990, Figure 2 indicates that fraudulent silence decisions, although fluctuating somewhat, generally increased after 1990 .

Of course, several variables affect the number of decisions in contract cases, including decisions by informed parties regarding whether to disclose information during the contracting process, filing behavior, settlement behavior, and statutory developments. Because we lack information relating to those factors, we do not theorize about why fraudulent silence decisions do not follow general trends of contract cases. Once again, however, these findings point to areas of potential research for those interested in patterns in contract and tort litigation.

\section{The data do not support specific claims made by commentators about trends over time.}

Some commentators make more specific claims about trends over time relating to the probability that courts will require the disclosure of material information. For example, recall from Part I that Professor Horwitz claims that, as the United States transitioned from an agrarian to a commercial economy, courts became more likely to require the disclosure of information not available to both parties. ${ }^{165}$ To test this claim, we ran a logistic regression

\footnotetext{
${ }^{164}$ Marc Galanter, Contract in Court; or Almost Everything You May or May Not Want to Know About Contract Litigation, 2001 Wis. L. Rev. 577, 598 (2001) (reporting, for example, that 2507 contract trials were held in federal district court in 1988 while 1517 trials were held in 1992, 1081 in 1996, and 902 in 1999).

${ }^{165}$ See supra note 97 and accompanying text.
} 
controlling for the twenty case characteristics, the year the case was decided, and an interaction term (ACCESS * YEAR), to pick up the trend over time in cases involving unequal access. The coefficient on the interaction term is insignificant $(p=0.72)$, indicating no significant trend over time exists. Our data thus do not support Horwitz's claim regarding changes in this area of the law due to changes in the economy.

In addition, in a paper published in 1978, Professor Kronman claimed that disclosure duties relating to latent defects increased dramatically during the twenty-five-year period between approximately 1953 and $1978 .^{166}$ To test this claim, we attempted to employ a logistic regression using the twenty variables related to case characteristics. This regression failed to produce results because many of the variables are perfect predictors of disclosure and several of the variables are collinear. Therefore, we employed simple tabulations to test the claim. We found that, prior to 1953, courts found a duty to disclose in 15 of the 16 cases (or 94\%) involving latent defects. In the twenty-five-year period between 1953 and 1978, 9 cases involved latent defects and, of those 9 cases, the court found a duty to disclose in 8 (or $89 \%$ ). A test for the equality of proportions finds no statistically significant difference between the percentages $(p=0.65)$. Therefore, our data do not support Kronman's claim about the development of the law relating to latent defects.

\section{G. Court}

\section{Courts located in the Mid-Atlantic states and the Southwest are} more likely to require disclosure than are courts located in other geographic regions. In addition, in contrast to the statements of some commentators, courts located in the South are not more likely to require disclosure, either during the period over which our data span or historically.

We coded the cases for the geographic region in which the court sits to determine whether any geographic patterns emerged with respect to case outcomes. ${ }^{167}$ The basic regression results presented

\footnotetext{
${ }^{166}$ Kronman, supra note 1, at 23-24.

${ }^{167}$ States were assigned to geographic regions using the classification employed by the U.S. Embassy. See U.S. Diplomatic Mission to Germany, The Regions of the
} 
in Table 6 indicate that courts located in the South, West, and Northeast are no more likely to impose liability for fraudulent silence than are courts located in other regions. ${ }^{168}$ The results, however, do indicate that courts located in the Mid-Atlantic states and the Southwest are more likely to require disclosure than are courts located in other regions.

As discussed in Part I, some commentators claim that southern states historically were much less likely to impose disclosure duties on bargaining parties than were states in other regions. ${ }^{169}$ To test this claim, we employed two strategies. First, we ran a logistic regression controlling for the twenty case characteristics, the year the case was decided, and geographic regions (represented by SOUTH, WEST, MIDATLANTIC, SOUTHWEST, and NEWENGLAND with MIDWEST as the base) to test for regional differences over particular periods. The first regression, using data only from cases decided between 1793 and 1860, failed because several independent variables were perfect predictors of the likelihood that the court would mandate disclosure. ${ }^{170}$ The second regression used data only from cases decided between 1861 and 1940. The coefficient on the variable SOUTH is insignificant $(p=0.94)$, indicating no significant difference between cases decided in the South and other regions during this period of time. For the sake of completeness, we ran the same regression using only cases decided between 1941 and 2002. Again, the coefficient on SOUTH was not statistically significant $(p=0.92)$.

Our second strategy involved calculating the proportion of cases in each region that imposed liability for two early periods: 17931860 and 1860-1940. We also performed similar calculations for the period 1941-2002 for purposes of comparison. The tabulations

United States, http://usa.usembassy.de/travel-regions.htm (last accessed Sept. 17, 2005).

${ }^{168}$ We used the variable MIDWEST as the base to run the regressions. When we mclude MIDWEST in the model and use another region as the base, we find that the coefficient on MIDWEST is not significantly different from zero. Therefore, courts in the Midwest are no more or less likely to impose liability for fraudulent silence than courts in other regions.

${ }^{169}$ See supra note 98 and accompanying text.

${ }^{170}$ For example, in all cases involving personal intentions (PERSONAL) the court imposed a duty to disclose. The same was true for LATENT, INSURE, CONFID, ACCESS, PROPERTY, LIED, and INTRINSIC. 
by outcome and by region for these three periods are presented in Table 8 .

\section{Table 8 \\ Tabulations for Decisions by Outcome and by Region}

\begin{tabular}{|c|c|c|c|c|c|c|}
\hline & \multicolumn{6}{|c|}{$1793-1860$} \\
\hline & SOUTH & WEST & MIDATLANTIC & SOUTHWEST & NEW ENGLAND & MIDWEST \\
\hline Disclosure Duty Found & $3(75 \%)$ & 0 & $6(75 \%)$ & 0 & $0(0 \%)$ & $1(50 \%)$ \\
\hline \multirow[t]{3}{*}{ Disclosure Duty Not Found } & $1(25 \%)$ & 0 & $2(25 \%)$ & 0 & $1(100 \%)$ & $1(50 \%)$ \\
\hline & \multicolumn{6}{|c|}{$1861-1940$} \\
\hline & SOUTH & WEST & MIDATLANTIC & SOUTHWEST & NEW ENGLAND & MIDWEST \\
\hline Disclosure Duty Found & $19(61 \%)$ & $4(40 \%)$ & $29(91 \%)^{* * *}$ & $4(67 \%)$ & $5(56 \%)$ & $28(74 \%)$ \\
\hline \multirow[t]{2}{*}{ Disclosure Duty Not Found } & $12(39 \%)$ & $6(60 \%)$ & $3(9 \%)$ & $2(33 \%)$ & $4(44 \%)$ & $10(26 \%)$ \\
\hline & \multicolumn{6}{|c|}{ 1941-2002 } \\
\hline$\cdot$ & SOUTH & WEST & MIDATLANTIC & SOUTHWEST & NEW ENGLAND & MIDWEST \\
\hline Disclosure Duty Found & $33(41 \%)$ & $34(61 \%)^{* *}$ & $23(35 \%)$ & I $4(47 \%)$ & $10(46 \%)$ & $24(34 \%)$ \\
\hline Disclosure Duty Not Found & $48(59 \%)$ & $22(39 \%)$ & $43(65 \%)$ & $16(53 \%)$ & $12(54 \%)$ & $46(66 \%)$ \\
\hline
\end{tabular}

* Significantly lower proportion of cases decided in the South as compared to this region, at the $10 \%$ significance level $(p<0.10)$.

** Significantly lower proportion of cases decided in the South as compared to this region, at the $5 \%$ significance level $(p<0.05)$.

*** Significantly lower proportion of cases decided in the South as compared to this region, at the $1 \%$ significance level $(p<0.01)$.

TABLE 8: This table presents the results of tabulations of the number of decisions by outcome and by region for three periods: 1793-1860, 1861-1940 and 1941-2002. Two-sample, one-sized tests for the equality of proportions were performed to compare the proportion of decisions finding a duty to disclose and decided in the South to the proportion of decisions finding a duty to disclose and decided in another region. For each test, the null hypothesis of equal proportions was tested against the alternative hypothesis that the proportion of decisions finding a disclosure duty and decided in the South is significantly less than the proportion of decisions finding a disclosure duty and decided in another region.

For the period 1793-1860, only fifteen cases are contained in the total sample, and only four of those were decided in the South. In three of the four cases, disclosure was required. This proportion is equal to the proportion of cases decided in the Mid-Atlantic states in which the court required disclosure. All other regions require disclosure in a smaller percentage of cases. Although the number of observations is very small, the data for this period support the claim that the South was less likely to impose a duty to disclose. 
For the periods $1861-1940$ and $1941-2002$, tests for the equality of proportions were performed to compare the proportion of cases requiring disclosure and decided in the South to the proportion of cases requiring disclosure and decided in each of the other regions. Five separate tests (one for each region) were performed for each period. For each test, the null hypothesis of equal proportions was tested against an alternative hypothesis that the proportion of cases requiring disclosure and decided in the South is significantly less than the proportion of cases requiring disclosure and decided in the region of comparison.

Only two of the ten tests indicate that the South is significantly less likely to require disclosure as compared to other geographic regions. First, during the period 1861-1940, courts in the South were less likely to require disclosure than were courts in the MidAtlantic states. Second, during the period 1941-2002, courts in the South were less likely to require disclosure than were courts in the West. Otherwise, no statistically significant difference exists between the proportion of cases decided in the South finding a duty to disclose and the proportion of similarly decided cases in courts located in other regions finding a duty to disclose. Therefore, the data do not provide strong support for the claim that southern states historically were less likely to require disclosure as compared to other regions of the country.

2. State courts are no more or less likely than federal courts to require the informed party to reveal information to the uninformed party. In addition, the Third Circuit, Sixth Circuit, and Seventh Circuit are more likely than any other circuit to require disclosure.

As indicated in Part $I$, we were interested in determining whether courts differ by jurisdiction in terms of how likely they are to require disclosure. Specifically, we were interested in whether any differences existed between federal and state courts, or among the federal appellate circuits.

The results presented in Table 6 indicate that the coefficient on STATE is significant and positive $(p=0.04)$ when we control only for variables relating to the 20 case characteristics. This provides some evidence for the claim that state courts are more likely than federal courts to impose duties to disclose. When we add controls for the case decision year, geographic regions, and federal appel- 
late circuit, however, the coefficient loses significance. This lack of robustness suggests that any difference between federal and state courts on this issue is weak at best. When all independent variables are included in the model, the coefficient on STATE becomes statistically insignificant $(p=0.28)$, indicating that state courts are no more or less likely to require disclosure than are federal courts.

In addition, the results obtained from the regression analysis (see Table 6) indicate that three federal appellate jurisdictions are less likely to require disclosure than any other federal appellate jurisdiction: the Third Circuit $(p=0.08)$, the Sixth Circuit $(p=0.02)$, and the Seventh Circuit $(p=0.05)$. We cannot offer conjectures about why these particular circuits are less likely to impose a duty to disclose on informed parties but leave this task for other researchers. One potentially interesting research question that arises from this finding is whether these results reflect broader trends in these circuits beyond fraudulent silence cases.

\section{H. A Note on Priest-Klein}

Courts found a duty to disclose in approximately $51 \%$ of the cases in the sample. This statistic is consistent with the Priest-Klem litigation model, which implies that, because only close cases are likely to proceed to litigation (with clear cases being settled or never brought at all), "the formal structure of the law [will] appear indeterminate to any scientific, empirical method of observing judicial decisions." ${ }^{171}$ In other words, the model suggests that it is impossible to identify factors that significantly influence outcomes given that all litigated cases are perched on the knife-edge. In roughly half of the cases, they theorize, the outcome randomly falls to one side of the knife; in the other half, it randomly falls to the other side.

For this reason, under the Priest-Klein model, our analysis is futile: if the model is truly predictive, then our analysis should fail to discover any significant drivers of outcomes. As this Part has revealed, however, nearly half of our independent variables significantly influence court decisions regarding whether the informed party had a duty to disclose information to the uninformed party. Therefore, we are left to explain these seemingly contradictory re-

\footnotetext{
${ }^{171}$ See Priest \& Klein, supra note 104, at 6.
} 
sults (that is, the finding of statistically significant factors that seem to drive outcomes (contrary to the Priest-Klein predictions) despite the fact that the outcomes are nearly evenly divided (consistent with the Priest-Klein predictions)).

One could claim that our results are simply spurious. Given the pattern of our results, however, we do not believe this is the case. For example, the factors found to significantly influence outcomes do not appear to be random. Instead, we find that many of the factors that significantly increase the probability that a court will impose a duty to disclose are also the most widely-accepted, such as the factors listed in the Restatement of Contracts (that is, whether the parties are in a fiduciary or confidential relationship, whether the information is related to a latent defect, and whether the information would have updated or corrected previously disclosed information). ${ }^{172}$

In addition, as a matter of theory, there are reasons to doubt that the Priest-Klein model holds when studying outcomes on the element of the duty to disclose in fraudulent silence claims. In a fraudulent silence case, the imposition of a duty to disclose is only one element of a multi-element cause of action in which the plaintiff must also prove elements such as scienter, reliance, and materiality. As a result, even when the plaintiff can easily show that the defendant had a duty to disclose, the case nonetheless might proceed to the litigation and opinion stage due to the parties' uncertainty about another element. As a result, cases in which the element of duty is on the knife-edge are but a subset of the cases in our sample and, therefore, our regression analysis is able to identify factors that significantly influence outcomes on the duty element.

Given that our analysis focuses on just one element - duty- of a multi-element cause of action-fraudulent silence-one might question why we do not observe a larger majority of outcomes on the duty element favoring the plaintiff. ${ }^{173}$ It must be remembered, however, that plaintiffs may sometimes raise claims that they have a small probability of winning. This is true, for example, of suits in

\footnotetext{
${ }^{172}$ See Restatement (Second) of Contracts $\$ 161$ (1979).

${ }^{173}$ One could argue that, if the duty element is not an element that is balanced on the knife-edge, then it must be an element on which the plaintiff is more likely to win. Otherwise, one might speculate that rational plaintiffs would not bring the case.
} 
which plaintiffs have one or more relatively strong claims, but can allege other, weaker, claims based on the same fact pattern. Under such circumstances, the marginal cost of adding an additional weak claim to the suit is essentially zero. ${ }^{174}$ Under these circumstances, the plaintiffs' success rate on the duty element could be less than $50 \%$. For these reasons, the fact that we observe $50 \%$ of the outcomes on the duty element favoring the plaintiff might very well be anomalous and unrelated to the predictions of the Priest-Klein model.

\section{CONCLUSION}

The question of when an individual in possession of valuable information unknown to her contracting partner has the right to remain silent and profit from her secret knowledge has fascinated scholars in philosophy, law, and history since ancient times. Many have developed specific and general "meta-theories" to explain the variation in case outcomes. Few, however, have attempted to systematically analyze the cases, and none has employed regression analysis to isolate the effects of particular factors on case outcomes.

Our analysis calls into question much of the conventional wisdom regarding the law of fraudulent silence. In fact, our results fail to support several of the most prominent theories that have been asserted to explain when courts will require full disclosure between contracting parties. Specifically, our data do not support the contentions that courts more frequently require the disclosure of intrinsic information than extrinsic information; that courts insist on the disclosure of information that could prevent bodily injury or property damage; that informed parties are able to freely withhold information regarding personal intentions or opinions; that those seeking insurance, surety, or a release from liability must disclose all relevant information; that courts more frequently require disclosure in transactions relating to the sale or transfer of real prop-

${ }^{174}$ For example, consider cases in which the plaintiff's strongest claim is that the defendant affirmatively misrepresented a material fact. In cases such as these, the plaintiff might find that the marginal cost of adding even a weak claim to the suit alleging affirmative misrepresentation is essentially zero. In other words, if the facts giving rise to an affirmative misrepresentation claim also give rise to an albeit weak fraudulent silence claim, then the plaintiff might tack on the weak fraudulent silence claim. 
erty; that courts tend not to require the disclosure of deliberately acquired information; that courts have become more likely to require disclosure over time; or that southern states are less likely to require disclosure than are states in other regions of the country.

In some cases, however, the data do support conventional wisdom. In particular, the data support the hypotheses that courts are more likely to require the disclosure of latent, as opposed to patent, defects; that courts are more likely to require the disclosure of information that would update or correct previously disclosed information; that courts are more likely to require full disclosure between parties in a fiduciary or confidential relationship; that courts are more likely to require the disclosure of illegally or tortiously acquired information; and that courts are more likely to require disclosure when the uninformed party is a buyer or lessee.

In addition, our own intuition that courts are swayed by the sympathetic nature of the uninformed party and the bad behavior of the informed party are supported by the data. Courts are significantly more likely to require disclosure when the uninformed party is sick, disabled, illiterate, or elderly, though still competent to contract. Also, courts are more likely to require disclosure when the informed party lied or told half-truths in the same transaction in which the omission occurred, or when the informed party took affirmative steps to conceal the withheld information. Our suspicion, however, that courts are more likely to require disclosure when the uninformed party is female is not supported by the data, although our data did reveal a time trend in fraudulent silence decisions when the uninformed party is female. The percentage of cases in which the uninformed party is female and the court required disclosure decreased significantly from the period $1793-1950$ to the period 1951-2002.

Perhaps most importantly, our analysis suggests that the longstanding and heated debate between those who argue that courts attempt primarily to enhance fairness by placing contracting parties on a more even playing field and those who argue that courts attempt primarily to enhance economic efficiency by allowing informed parties to reap the benefit of knowledge that is deliberately acquired could be misplaced. Our data provide little, if any, support for the contention that courts are more likely to require the disclosure of casually, as compared to deliberately, acquired infor- 
mation. Regression results do indicate that courts are more likely to require the disclosure of information when the parties lack equal access. Our analysis, however, reveals that it is the presence of unequal access in combination with casually acquired information that drives case outcomes. Therefore, it is the presence of these two factors together, rather than either one independently, that significantly affects case outcomes.

We view this study merely as a first step toward unraveling a difficult and controversial area of law, rather than a definitive answer to the question of what drives outcomes in fraudulent silence cases. Although this study provides some answers, it raises many questions as well.

For example, although our data show that, contrary to conventional wisdom, courts have become less likely over time to require the disclosure of material information unknown to one's bargaining partner, does this mean that courts have become more prodefendant over time? Or have other factors, such as the codification of certain areas of fraudulent silence law through statutes that mandate particular disclosures, altered the type of case that survives to litigation under the common law? $?^{175}$ The answers to these questions, and others, however, are beyond the scope of this Article.

In addition, regression analyses on data spanning a twohundred-year period do not permit us to capture the law at any particular point in time. Alternative strategies (such as, for example, using regression analysis over moving windows of smaller time periods) allow such an analysis, however. Not only would this strategy more fully highlight any time trends in the data, but also it would permit testing for whether particular events or developments of note, such as, for example, the publication of the Restatement (Second) of Contracts, actually produced changes in the

${ }^{175}$ Common examples are statutes mandating certain disclosures in residential real estate transactions and car sales. Because such statutes are generally pro-plaintiff, if these statutes merely codify changes that were already occurring under the common law, then the cases remaiming to be decided under the common law could conceivably be those in areas of the law in which courts were not expanding disclosure duties. As a result, these cases would appear to reflect a pro-defendant trend that does not really exist. 
law (as has been asserted by some commentators), rather than simply restated the law. ${ }^{176}$

${ }^{176} \mathrm{G}$. Edward White, The American Law Institute and the Triumph of Modernist Jurisprudence, 15 Law \& Hist. Rev. 1, 46 (1997) (discussing the debate over whether the ALI only restates the law or attempts to revise it); Herbert P. Wilkins, Foreword to the Symposium on the American Law Institute: Process, Partisanship, and the Restatements of Law, 26 Hofstra L. Rev. 567, 569 (1998) (stating that some argue that the ALI often attempts to push the law in a particular direction, as opposed to simply restating the law). 


\section{APPENDIX A}

This appendix describes the data collection process undertaken for Common-Law Disclosure Duties and the Sin of Omission: Testing the Meta-Theories. The purpose of this appendix is to provide details regarding the population of cases from which we drew our sample and our case coding procedures.

\section{The Population of Cases From Which We Drew Our Sample}

The Allcases-old database includes documents from the United States Supreme Court, courts of appeals, district courts, former circuit courts, former Court of Claims, "related federal courts" (such as the tax and customs courts), and state and local courts. The federal documents included in the database are those opinions "released for publication" between 1789 and 1944. State and local coverage begins on various dates and extends through 1944 . $^{2}$

It is unclear from West's website whether "released for publication" refers only to documents officially released for publication or whether it also includes unpublished opinions that might have become available. Neither West's reference attorneys nor any other company representative was able to clarify this point. ${ }^{3}$ Because the practice (at least within the federal appellate courts) of disposing of cases through unpublished opinions is assumed by most commentators to have begun in 1964 , however, the issue of unpublished opinions is likely a greater problem in the Allcases database than in the Allcases-old database. ${ }^{4}$

The Allcases database includes decisions dated after 1944 from the United States Supreme Court, courts of appeals, district courts, bankruptcy courts, the Court of Federal Claims, the United States Tax Court, the Military Courts, and the state and local courts of all

\footnotetext{
${ }^{1}$ Westlaw, Westlaw Database Directory, http://directory.westlaw.com/scope/ default.asp?db=ALLCASES-OLD\&RS=WDIR2.0\&VR=2.0 (last accessed Sept. 17, 2005).

${ }^{2} \mathrm{Id}$.

${ }^{3}$ Telephone Interview with Reference Attorney, West, in Eagan, Minn. (Aug. 4, 2002).

${ }^{4}$ See infra note 15 and accompanying text (discussing the origination of the federal appellate non-publication and no-citation policies).
} 
the states and the District of Columbia. ${ }^{5}$ The Allcases database includes published as well as some unpublished opinions. ${ }^{6}$

Like many other studies attempting to empirically examine case law or judicial developments, this study is limited to the Westlaw database, which does not include all decided cases. Instead, Westlaw excludes some unpublished cases, thus biasing the results to the extent that there is some systematic difference between available and unavailable cases.

According to a Westlaw representative, West gathers unpublished opinions for inclusion in the Allcases database from three sources: (1) the Federal Appendix, a West publication; (2) opinions submitted to Westlaw for posting in the database directly by the deciding court; and (3) opinions submitted to Westlaw by attorneys.' The Federal Appendix does not contain all unpublished opinions. Specifically, the Third, Fifth and Eleventh Circuits do not permit publication of their unpublished opinions in the Appendix. ${ }^{8}$ In addition, the Fifth and Eleventh Circuits do not release their unpublished opinions for inclusion in the Westlaw or Lexis databases.'

Finally, West does not include in the Allcases database all unpublished opinions submitted for inclusion by attorneys. Instead, West reviews the submitted cases and selects "some" for inclusion. No Westlaw representative was able to provide further information on the selection process, what criteria were used to determine inclusion, or indicate what percentage of cases submitted for inclusion by attorneys was ultimately included in the database..$^{10}$

\footnotetext{
${ }^{5}$ Westlaw, Westlaw Database Directory, http:/directory.westlaw.com/scope/ default.asp?db=ALLCASES\&RS=WDIR2.0\&VR=2.0 (last visited Sept. 17, 2005).

"Id. An "unpublished" opinion is one which the court has determined should be excluded from the official reporter, ostensibly because the case contains no precedential value. Cf. Melissa M. Serfass \& Jessie L. Cranford, Federal and State Court Rules Governing Publication and Citation of Opinions, 3 J. App. Prac. \& Process 251 (2001) (outlining the guidelines for opinion publication and citation in each federal and state court of appeal).

${ }_{7}^{7}$ Telephone Interview with Reference Attorney, West, in Eagan, Minn. (Aug. 4, 2002).

${ }^{8}$ Brian P. Brooks, Publishing Unpublished Opinions, 5 Green Bag 259, 260 (2002).

9 See David Greenwald \& Frederick A.O. Schwarz, Jr., The Censorial Judiciary, 35 U.C. Davis L. Rev. 1133, 1150 n.64 (2002).

${ }^{10}$ Telephone Interview with Reference Attorney, West, in Eagan, Minn. (Aug. 4, 2002).
} 
West's failure to include all decided cases in the on-line database could significantly impact our results. Specifically, the unpublished federal appellate decisions seem more likely to be included on Lexis and Westlaw than are unpublished state court decisions. For this reason, if there is some systematic difference between federal appellate court decisions and state court decisions, this differential inclusion in the Westlaw database could affect the results of this or any other study relying on the Westlaw database. Similarly, because the Fifth and Eleventh Circuits do not release their unpublished opinions for inclusion on Westlaw or Lexis, if there is some systematic difference between the Fifth and Eleventh circuits on the one hand, and the other eleven circuits on the other hand, this difference might bias the results of this and any other study that employs the Westlaw database.

Given that, in the federal appeals courts alone, over eighty percent of the caseload is disposed of through unpublished opinions, this is a potentially glaring omission." Although federal unpublished opinions have no precedential value in most jurisdictions, ${ }^{12}$ many commentators argue that unpublished opimions, nonetheless, are important. ${ }^{13}$ Accordingly, readers should at least be aware of the potential limits of this or any other study based on the on-line databases. $^{14}$

${ }^{11} 2001$ Admin. Off. of the U.S. Courts Ann. Rep. of the Director Table S-3, at 40, available at http://www.uscourts.gov/judbus2001/tables/s03sep01.pdf.

${ }^{12}$ Currently, only the Fourth, Sixth and D.C. Circuits permit the citation of unpublished opinions as precedent. See 4th Cir. R. 36(c) (laying out the 4th Circuit's rule); 6th Cir. R. 28(g) (laying out the 6th Circuit's rule); D.C. Cir. R. 28(c) (laying out the DC Circuit's rule). The rules regarding the precedential value of unpublished opinions are contained in the court rules for each circuit. For a discussion of the rules, see Jason B. Binimow, Annotation, Precedential Effect of Unpublished Opinions, 105 A.L.R.5th 499 (2005); David Vladeck \& Mitu Gulati, Judicial Triage: Reflections on the Debate Over Unpublished Opinions, 62 Wash. \& Lee L. Rev. (forthcoming Fall 2006).

${ }^{13}$ See, e.g., Suzanne O. Snowden, "That's My Holding and I'm Not Sticking to It!" Court Rules That Deprive Unpublished Opinions of Precedential Authority Distort the Common Law, 79 Wash. U. L.Q. 1253, 1257 (2001) (arguing that unpublished opinions often would have had important future precedential value if they had been published).

${ }^{14}$ For a general discussion on the limitations of empirical studies of case outcomes, sec Robert B. Thompson, Piercing the Corporate Veil: An Empirical Study, 76 Cornell L. Rev. 1036, 1045-47 (1991). 
Although the problem of officially unpublished cases does not likely affect the Allcases-old database-the practice is generally assumed to have begun with the 1964 Federal Judicial Conference ${ }^{15}$ surveys of older American case law suffer from an even greater problem: the lack of case reporting during the early years of American independence. In the early years of the history of the American courts, lack of reporting of decided cases was a serious problem. ${ }^{16}$ Lawyers had to make do with reports of English cases, which were still widely used even after American independence, and notebooks of decisions that lawyers maintained for their own use and use by their colleagues and friends. ${ }^{17}$

Even opinions of the United States Supreme Court were difficult to obtain in the early years. The Court often failed to reduce even its most important decisions to writing. ${ }^{18}$ the reporters did not include all decisions in their reports, perhaps excluding, in some cases, as many as half; ${ }^{19}$ reports were often unavailable for periods of up to eight years after the end of the Supreme Court term; ${ }^{20}$ and the reports of some reporters, at least, were heavily criticized, even by their contemporaries and the justices themselves, as being inac-

\footnotetext{
${ }^{15}$ See, e.g., Greenwald \& Schwartz, supra note 9, at 1141; Deborah Jones Merritt \& James J. Brudney, Stalking Secret Law: What Predicts Publication in the United States Courts of Appeals, 54 Vand. L. Rev. 71, 75-76 (2001).

${ }^{16}$ See 5 U.S. (1 Cranch) iii-v (1804) ("Much of that uncertainty of the law, which is so frequently, and perhaps so justly, the subject of complaint in this country, may be attributed to the want of American reports."), quoted in Craig Joyce, The Rise of the Supreme Court Reporter: An Institutional Perspective on Marshall Court Ascendancy, 83 Mich. L. Rev. 1291, 1308 (1985) (discussing the problem of nonreporting of cases in the early years of the American court system).

${ }^{17}$ Id. at 1297; see also Erwin C. Surrency, Law Reports in the United States, 25 Am. J. Legal Hist. 48, 49 (1981) (discussing the prevalence of English law reports in eighteenth-century estates).

${ }^{18}$ Joyce, supra note 16 , at 1298 n.46, 1304 n.77 (quoting a telephone conversation with Maeva Marcus, Coeditor of the Documentary History Project, where she states, "It seems odd that if opinions were written, not a single one in the hand of a justice survives. So it is likely that few, if any, ever existed.").

${ }^{19}$ Id. at 1303 (discussing the incompleteness of the reports of Alexander James Dallas, the Court's first-though unofficial-reporter); id at 1329-30 (discussing the omission of cases by Henry Wheaton, the Court's third-and first official-reporter).

${ }^{20}$ Id. at 1327-28 (noting that Dallas and William Cranch, the Court's secondthough unofficial-reporter, had allowed Supreme Court cases to go unreported for eight and six years, respectively). These delays were corrected by Wheaton, who generally published the reports of the prior term in time for the start of the next. Id.
} 
curate. ${ }^{21}$ One can only assume that reports of state and lower federal cases suffered from similar problems.

Readers thus should bear in mind that our only historical record of early court decisions might be substantially inaccurate. Again, this is an unavoidable failing of all studies of early case law, and we do not feel that it renders our results any less important or robust.

\section{Case-Coding Procedures}

Case coding was done by research assistants, with the supervision of one of the authors. Weekly meetings were held as a group in order to assess progress, discuss the cases, and answer questions. Steps were taken to enhance the consistency of coding by the different research assistants. These steps include the adoption of bright-line rules, where possible, and several weeks of individually coding the same set of cases and discussing them as a group. Once the group was able to consistently reach the same coding results, coding on the project began. In addition, once the initial case coding was complete, all of the coding was double-checked by a research assistant who had not been involved in the initial coding project. The reliability test resulted in a match of roughly $90 \%$ of the data coded by the original coders.

Not all cases retrieved by the search terms were includable in the study. For example, a small percentage of cases contained all of the specified search terms, yet did not address the question being studied. In addition, we were unable to code some cases, either because the court did not reach a decision on the merits of the case, or because the opinion did not contain sufficient information to allow for complete coding of all the independent variables. When the case included in our sample was an appeal from a lower court decision and that lower decision was available on Westlaw, the research assistants sometimes referred to the lower court decision to

\footnotetext{
${ }^{21}$ Id. at 1304-05 (discussing the inaccuracy of Dallas's reports), 1309-10 (discussing inaccuracies in the reports of Cranch), 1361 (discussing criticisms of the reports of Richard Peters, Jr., the Court's fourth reporter). The problem of inaccuracy probably stemmed from many causes, including commercial considerations and the fact that some reporters (notably, Dallas) included reports of cases of which they did not have first-hand knowledge, but instead which were reconstructed from the notes of attorneys in attendance. Id. at 1305 . One exception to these criticisms of inaccuracy appears to be Wheaton, who reportedly was "fanatical" on this point. Id. at 1329-30.
} 
ascertain the complete facts necessary to code the case. In rare cases, a court did not reach a decision on the merits of the case, but nonetheless clearly indicated how it would have ruled if forced to decide the case. Such cases were included in our dataset, despite the lack of a formal resolution to the dispute.

Cases in which the common law had been altered due to a waiver, warranty, or statute were excluded from the dataset. For example, a waiver might alter the common law by waiving the uninformed party's rights to sue for nondisclosure under common law. This would include items sold "as is." Similarly, a warranty might enhance the uninformed party's status under the common law by guaranteeing the value or suitability of the item in question.

Finally, the research assistants checked all the cases in our dataset for negative direct history. If a lower court's fraudulent silence decision was reversed and remanded specifically on the element of the existence of a duty to disclose, then the lower court case was excluded from our dataset. The appellate decision also was excluded unless the appellate court reached a decision on the merits of the duty element. If, however, a lower court case was overturned for procedural reasons or on a point of law unrelated to the duty to disclose issue, then the lower court case was included in our dataset, despite the fact that the holding technically no longer stands. 